UNIVERSIDADE ESTADUAL PAULISTA “JÚLIO DE MESQUITA FILHO” FACULDADE DE CIÊNCIAS AGRONÔMICAS

CAMPUS DE BOTUCATU

\title{
PORTA-ENXERTOS, CONCENTRAÇÕES DE POTÁSSIO NA RESISTÊNCIA À Didymella bryoniae E RELAÇÕES FISIOLÓGICAS DO MELOEIRO
}

EDVAR DE SOUSA DA SILVA

Dissertação apresentada à Faculdade de Ciências Agronômicas da UNESP - Campus de Botucatu, para obtenção do título de Mestre em Agronomia - Área de Concentração em Horticultura.

BOTUCATU - SP

Fevereiro 2010 
UNIVERSIDADE ESTADUAL PAULISTA “JÚLIO DE MESQUITA FILHO” FACULDADE DE CIÊNCIAS AGRONÔMICAS

CAMPUS DE BOTUCATU

\section{PORTA-ENXERTOS, CONCENTRAÇÕES DE POTÁSSIO NA RESISTÊNCIA À Didymella bryoniae E RELAÇÕES FISIOLÓGICAS DO MELOEIRO}

\section{EDVAR DE SOUSA DA SILVA}

Orientador: Prof ${ }^{a}$. Dra ${ }^{a}$. Rumy Goto

Co-orientadores: Prof. Dr. Edson Luiz Furtado

Prof. Dr. Dirceu Maximino Fernandes

Dissertação apresentada à Faculdade de Ciências Agronômicas da UNESP - Campus de Botucatu, para obtenção do título de Mestre em Agronomia - Área de Concentração em Horticultura.

BOTUCATU - SP

Fevereiro 2010 


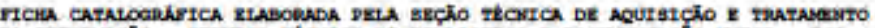

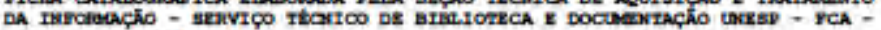
IAGEDO - BOTUCATU (BS)

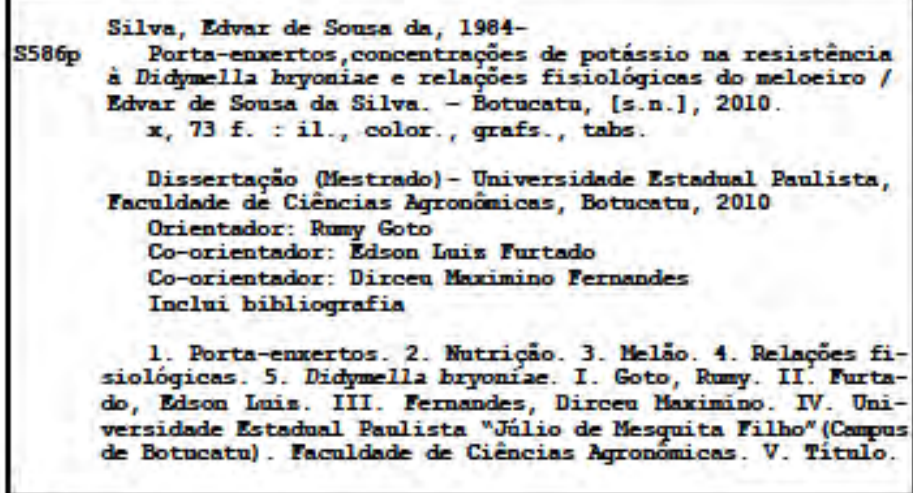




\title{
UNIVERSIDADE ESTADUAL PAULISTA "JÚLIO DE MESQUITA FILHO" FACULDADE DE CIÊNCIAS AGRONÔMICAS \\ CAMPUS DE BOTUCATU \\ CERTIFICADO DE APROVAÇÃo
}

\begin{abstract}
TÍTULO: "PORTA-ENXERTOS, CONCENTRAÇÕES DE POTÁSSIO NA RESISTÊN CIA A Didymella bryoniae E RELAÇõES FISIOLÓGICAS DO MELOEIRO"
\end{abstract}

\author{
ALUNO: EDVAR DE SOUSA DA SILVA \\ ORIENTADORA: PROFA. DRA. RUMY GOTO \\ CO-ORIENTADORES: PROF. DR. EDSON LUIZ FURT ADO \\ PROF. DR. DIRCEU MAXIMINO FERNANDES
}

Aprovado pela Comissão Examinadora

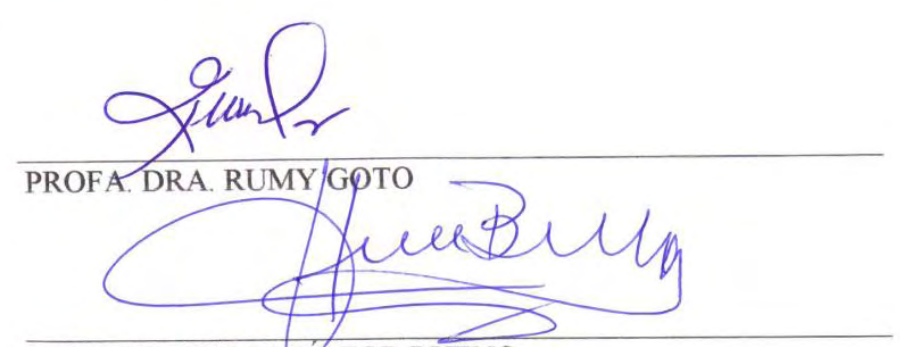

PROF. DR. CESAR UUNIOR BUENO

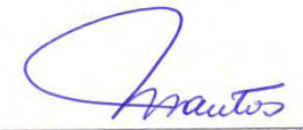

PROFA. DRA. HAYDÉE SIQUEIRA SANTOS

Data da Realização: 09 de fevereiro 2010. 


\section{BIOGRAFIA DO AUTOR}

\section{EDVAR DE SOUSA DA SILVA - Nasceu em Sítio Novo do} Tocantins - TO, no dia 14 de julho de 1984. Em abril de 2004, iniciou o curso de graduação em Licenciatura em Ciências Agrícolas na Universidade Federal Rural do Rio de Janeiro UFRuralRJ, localizada em Seropédica - RJ. Durante o curso foi bolsista de Iniciação Científica no programa PIBIC/CNPq - UFRuralRJ entre agosto de 2005 e julho de 2007, e monitor na disciplina de Didatica de Ciências Agrícolas do Departamento de Teoria e Planejamento de Ensino do Instituto de Educação da UFRuralRJ de junho a agosto de 2007. Concluiu o curso de Licenciatura em Ciências Agrícolas em 2007. 


\section{DEDICO}

Aos meus pais, Joaci da Silva e Francisca Bernardo de Sousa (In memoriam), responsáveis pelos verdadeiros valores da vida que tenho.

À Luciana Castello Branco, pelo apoio, incentivo, companheirismo e compreensão em todos os momentos.

Aos meus irmãos, Eduardo, Edvaldo, Edvan, Edna, Edileuza, Zilda, Maria, Odete, Joseane, Joceane, Josilene, a minha madrasta Anizete, por me fazerem sempre compreender como é bom ter uma família.

\section{AGRADEÇO}

\footnotetext{
À DEUS,

Por estar presente na minha vida em todos os momentos, me guiando por diversos caminhos e me ajudando a perseverar, pois Ele vê e conhece nosso coração.
} 


\section{AGRADECIMENTOS}

À Faculdade de Ciências Agronômicas / Universidade Estadual Paulista - Júlio de Mesquita Filho.

À CAPES pela concessão da bolsa para minha manutenção neste trabalho.

À Prof ${ }^{a} \operatorname{Dr}^{\mathrm{a}}$ Rumy Goto, pela orientação, amizade, por passar seus preciosos conhecimentos em horticultura e pelos agradáveis momentos de descontração.

Ao Prof $\operatorname{Dr}^{\circ}$ Edson Luiz Furtado, por ter compartilhado seus conhecimentos em fitopatologia, além de participar na realização dos experimentos.

Ao Prof ${ }^{\circ} \operatorname{Dr}^{\circ}$ Dirceu Maximino Fernandes, por ter compartilhado seus conhecimentos em nutrição mineral, além de participar na realização dos experimentos.

À Prof ${ }^{\mathrm{a}} \operatorname{Dr}^{\mathrm{a}}$ Martha Maria Mischan, pela paciência em me ajudar e passar seus preciosos conhecimentos de estatística.

Aos funcionários da Fazenda Experimental de Pesquisa e Produção (FEPP) da UNESP em São Manuel - SP, pelo auxílio prestado durante todo o experimento e por passarem seus conhecimentos durante os proveitosos e agradáveis dias de convivência.

Ao José Geraldo Severino Campos e o Nilton Aparecido de Moraes pela presença e ajuda durante todos os experimentos.

Aos colegas do laboratório de Patologia Florestal - Defesa Fitossanitária. Em especial a Martha, Cris e Juan pela ajuda, amizade e momentos agradáveis de descontração.

Ao funcionário Gilberto Winckler da Engenharia Rural, por ajudar e passar seu precioso conhecimento em tensiômetros.

As empresas Sakata Seed Sudamerica Ltda. (pelo fornecimento dos isolados de Didymella bryoniae), Syngenta Seeds Ltda e Takii do Brasil Ltda (pelo fornecimento das sementes dos porta-enxertos).

Aos meus amigos e companheiros de república, Manoel e Nelson, por terem compartilhado diversos momentos, e contribuíram muito para meu crescimento como pessoa. 
Ao Felipe Campaner Palangana pelo apoio e ajuda principalmente no segundo experimento.

À Ana Claudia pela ajuda, principalmente nas avaliações de trocas gasosas das plantas.

Aos que já não chamo mais de amigos, mas de irmãos do grupo de oração Divina Misericórdia, Sandra, Jackson e Adriana, Eleide, Amilton, Juliana, Renata, Ana Carolina, Bárbara, Juliana Campana, Rafael e Rômulo, irmãos que nasceram pela fé. 


\section{SUMÁRIO}

Página

LISTA DE TABELAS........................................................................................ VII

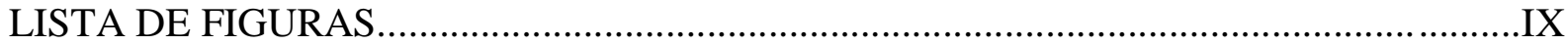

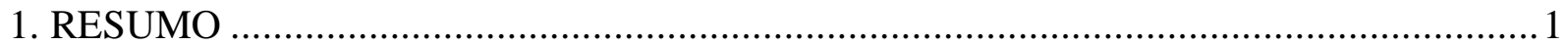

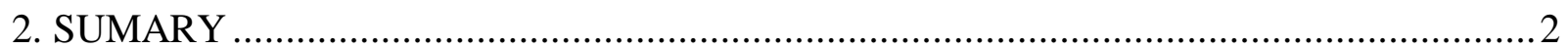

3. INTRODUÇÃ

4. REVISÃO DE LITERATURA........................................................................ 5

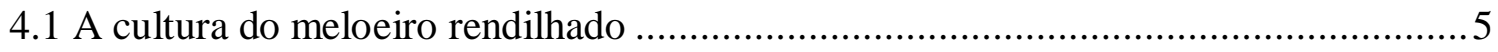

4.2 Didymella bryoniae ........................................................................... 7

4.2.1 Sintomatologia e epidemiologia .................................................. 7

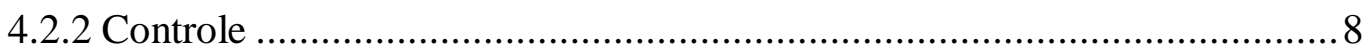

4.3 Nutrição mineral e resistência a doenças ......................................................... 9

4.4 Relação do potássio com doenças e pragas ..................................................... 11

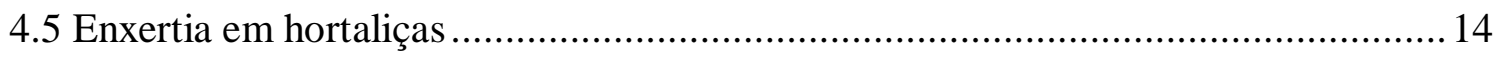

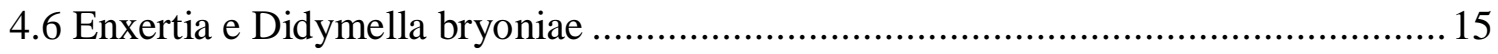

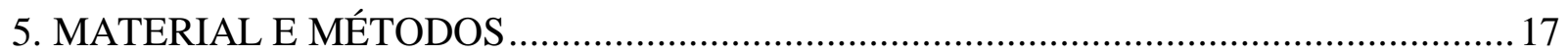

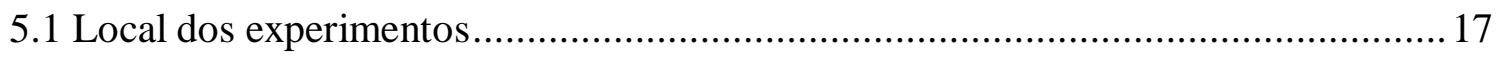

5.2 Reação de porta-enxertos de meloeiro a isolados de Didymella bryoniae ................ 17

5.2.1 Delineamento experimental ........................................................... 17

5.2.2 Caracterização do solo ............................................................ 18

5.2.3 Condução dos portas-enxertos ....................................................... 19

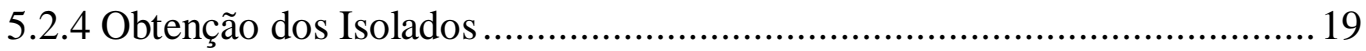

5.2.5 Método de inoculação nos experimentos........................................... 19

5.3 Concentrações de potássio na resistência do meloeiro rendilhado híbrido 'Bônus II' enxertado e pé-franco a Didymella bryoniae .................................................. 21

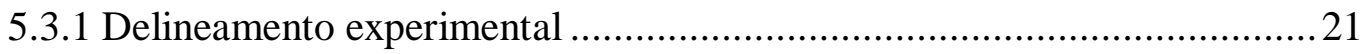

5.3.2 Correção e adubação do solo ......................................................... 22

5.3.3 Condução das plantas .............................................................. 23

5.3.4 Manejo da irrigação e fertirrigação ................................................... 24 
5.3.5 Medidas de trocas gasosas nas plantas 27

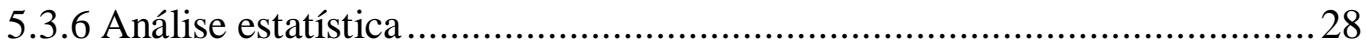

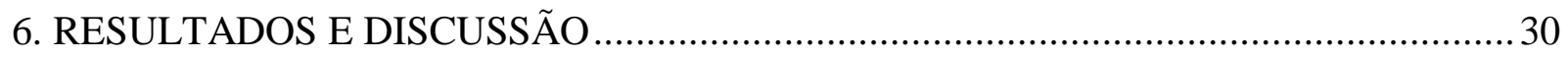

6.1 Reação de porta-enxertos de meloeiro a isolados de Didymella bryoniae ................ 30

6.2 Concentrações de potássio na resistência do meloeiro rendilhado híbrido Bônus II enxertado e pé-franco a Didymella bryoniae .....................................................39

6.2.1 Pega de frutos...................................................................... 40

6.2.2 Diâmetro médio da lesão em função das plantas enxertadas e concentrações

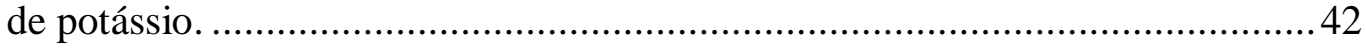

6.2.3 Sobrevivência das plantas em função da enxertia e concentrações de

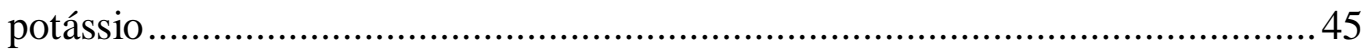

6.2.4 Trocas gasosas em função da enxertia e concentrações de potássio ..........48

6.2.5 Condutividade elétrica e $\mathrm{pH}$ da solução do solo ...................................59

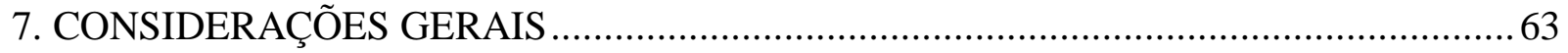

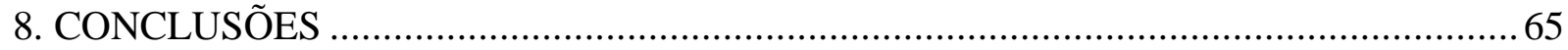

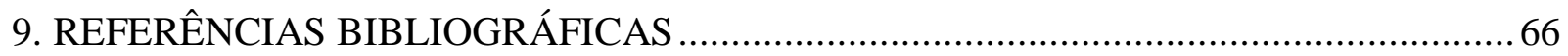




\section{LISTA DE TABELAS}

Tabela

Página

01. Efeitos de potássio (K) na incidência de doenças. Número e (porcentagem) de indicações..

02. Efeito do K sobre doenças em algumas cucurbitáceas..................................... 13

03. Características físicas do solo utilizado no experimento..................................... 18

04. Características químicas do solo utilizado no experimento............................... 18

05. Isolados de Didymella bryoniae obtidos em diferentes regiões do Brasil............. 19

06. Características químicas do solo utilizado no experimento.................................. 23

07. Extrações dos nutrientes nitrogênio $(\mathrm{N})$ e potássio $(\mathrm{K})$ pelo meloeiro rendilhado cultivado em ambiente protegido............................................................... 27

08. Esquema de análise de variância dos ensaios................................................... 28

09. Resumo da análise de variância do fatorial do diâmetro médio da lesão do fungo Didymella bryoniae, em função dos porta-enxertos e dos isolados provenientes de quatro regiões do Brasil.

10. Médias gerais do diâmetro médio da lesão em $\mathrm{cm}$ do fungo D. bryoniae, em função dos porta-enxertos (P.E.) e dos isolados provenientes de quatro regiões do Brasil.

11. Diâmetro médio da lesão $(\mathrm{cm})$ do fungo D. bryoniae aos 14, 21 e 28 DAI (Dias após inoculação).

12. Coeficiente de determinação $\left(\mathrm{R}^{* 2}\right)$, obtido da regressão linear entre os valores previstos (variável dependente) e observados (variável independente) para os porta-enxertos e os isolados de Didymela bryoniae.....

13. Paralelismo das retas do diâmetro médio da lesão em função das épocas de avaliação em cada porta enxerto, efetuado através do pacote estatístico ESTAT (Jaboticabal)

14. Resumo da análise de variância da pega de frutos em plantas de Bônus II péfranco e enxertadas em melão 'Dinero' e abóbora 'Strong Tosa'. 
15. Resumo da análise de variância do fatorial do diâmetro médio da lesão em 42 função do tipo de planta e concentrações de potássio.

16. Resumo da análise de variância do fatorial do número médio de plantas por parcela em função do tipo de planta e concentrações de potássio.

17. Resumo da análise de variância do fatorial da taxa de assimilação líquida de $\mathrm{CO}_{2}$ (A) em função do tipo de planta e concentrações de potássio.

18. Resumo da análise de variância do fatorial da condutância estomática $\left(\mathrm{g}_{\mathrm{s}}\right)$ em função do tipo de planta e concentrações de potássio.

19. Resumo da análise de variância do fatorial da taxa de transpiração (E) em função do tipo de planta e concentrações de potássio.

20. Resumo da análise de variância do fatorial da eficiência do uso da água em função do tipo de planta e concentrações de potássio.

21. Médias gerais da condutância estomática, em função do tipo de planta e concentrações de potássio aos 26 DAI.

22. Resumo da análise de variância da condutância estomática e taxa de transpiração nas plantas de 'Bônus II' aos 26 DAI.

23. Dados de temperatura $\left(\mathrm{T}^{\circ} \mathrm{C}\right)$ e radiação fotossinteticamente ativa (PAR) no dia da avaliação aos 26 DAI

24 Resumo da análise de variância da condutância estomática, taxa de transpiração e taxa de assimilação líquida de $\mathrm{CO}_{2}$ nas plantas de 'Bônus II' enxertadas em melão 'Dinero'

25. Resumo da análise de variância da condutância estomática, taxa de transpiração e taxa de assimilação líquida nas plantas de 'Bônus II' enxertadas em abobora 'Strong Tosa'. 


\section{LISTA DE FIGURAS}

Figura

Página

01. Método de inoculação com palito e disco de micélio do fungo........................... 20

02. Vista geral do experimento no ambiente protegido 74 dias após transplante e 54 dias após inoculação (DAI)....................................................................... 22

03. Tensiômetros de decisão e de controle, instalados na cultura do meloeiro........... 24

04. Curva de retenção de água no solo utilizada para o manejo das irrigações.......... 25

05. Temperatura máxima, mínima e média dentro do ambiente protegido de 29/09/2008 a 23/11/2008, em São Manuel-SP

06. Umidade relativa máxima, mínima e média dentro do ambiente protegido de 29/09/2008 a 23/11/2008, São Manuel-SP.

07. Progresso do crestamento gomoso ocasionado por isolados inoculados em porta enxertos de meloeiro......................................................................... 36

08. Porta-enxerto 'Dinero' 18 dias após inoculação.............................................. 37

09. Porta-enxerto 'Dinero' 30 dias após inoculação.............................................. 37

10. Porta-enxertos 'Strong Tosa', 'Calabash TI-191', 'Ojakkyo' 20 dias após inoculação................................................................................................... 38

11. Temperatura máxima, mínima e média dentro do ambiente protegido de 18/05/2009 a 18/09/2009, São Manuel-SP.

12. Umidade relativa máxima, mínima e média dentro do ambiente protegido de 18/05/2009 a 18/09/2009, São Manuel-SP.

13. Porcentagem de pega de frutos em plantas de 'Bônus II' pé-franco e enxertadas em melão 'Dinero' e abóbora 'Strong Tosa'.

14. Diâmetro médio da lesão $(\mathrm{cm})$ na região do porta-enxerto em plantas de 'Bônus II' enxertadas nos porta-enxertos 'Strong Tosa' e 'Dinero'

15. Lesão na região do porta-enxerto 'Dinero' aos 42 dias após inoculação.

16. Lesão na região do porta-enxerto 'Strong Tosa' aos 42 dias após inoculação.....

17. Planta de 'Bônus II' pé-franco aos 14 dias após inoculação 
18. Sobrevivência de plantas de meloeiro (\%) enxertadas e pé-franco a cada sete dias após a inoculação................................................................................. 46

19. Condutância estomática em plantas de Bônus II pé-franco em função das concentrações de potássio aos 26 DAI.......................................................... 52

20. Taxa de transpiração em plantas de Bônus II pé-franco em função das concentrações de potássio aos 26 DAI.......................................................... 53

21. Taxa de assimilação líquida de $\mathrm{CO}_{2}$ em plantas enxertadas aos 41 dias após a inoculação......................................................................................... 54

22. Condutância estomática em plantas enxertadas aos 41 dias após a inoculação... 54

23. Taxa de transpiração em plantas enxertadas aos 41 dias após a inoculação........ 55

24 Eficiência do uso da água em plantas enxertadas aos 41 dias após a

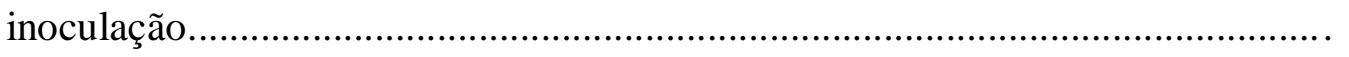

25. Condutância estomática em plantas de 'Bônus II' enxertadas com 'Strong Tosa’ em função das concentrações de potássio aos 75 dias após a inoculação.. 58

26. Taxa de transpiração em plantas de 'Bônus II' enxertadas com 'Strong Tosa' em função das concentrações de potássio aos 75 dias após a inoculação...

27 Condutividade elétrica (CE) da solução do solo nos tratamentos de 'Bônus II' pé-franco e enxertado nos porta-enxertos 'Dinero'e 'Strong Tosa' com as concentrações de potássio 0,125 e $250 \mathrm{mg} \mathrm{L}^{-1}$

28 pH da solução do solo nos tratamentos de 'Bônus II' pé-franco e enxertado nos porta-enxertos 'Dinero' e 'Strong Tosa' com as concentrações de potássio 0, 125 e $250 \mathrm{mg} \mathrm{L}^{-1}$ 


\section{PORTA-ENXERTOS, CONCENTRAÇÕES DE POTÁSSIO NA RESISTÊNCIA À Didymella bryoniae E RELAÇÕES FISIOLÓGICAS DO} MELOEIRO. Botucatu, 2010. 73 p. Dissertação (Mestrado em Agronomia) - Faculdade de Ciências Agronômicas. Universidade Estadual Paulista. Autor: EDVAR DE SOUSA DA SILVA

Orientadora: RUMY GOTO

Co-orientadores: EDSON LUIZ FURTADO

DIRCEU MAXIMINO FERNANDES

\section{RESUMO}

O controle químico tem sido utilizado freqüentemente com baixa eficiência para o fungo Didymella bryoniae, causador da doença crestamento gomoso ou cancro da haste em meloeiro. Porém, alternativas de controle como uso da enxertia e manipulação da nutrição devem ser estudadas. Avaliou-se porta-enxertos e concentrações de potássio na resistência de meloeiro rendilhado a Didymella bryoniae em ambiente protegido. No primeiro experimento, quatro porta-enxertos (melão 'Dinero', melancia 'Ojakkyo', abóbora 'Strong Tosa' e cabaça 'Calabash TI-191') foram inoculados com discos de micélio (7 mm de diâmetro) de quatro isolados de Didymella bryoniae (Dbr 34, Dbr 36, Dbr 37 e Dbr 39) em caule previamente ferido. Baseado no tamanho da lesão, o porta-enxerto 'Dinero' foi susceptível, 'Strong Tosa' moderadamente resistente, 'Ojakkyo' e 'Calabash TI-191' resistentes e o isolado Dbr 37 se mostrou mais agressivo dentre os isolados. No segundo experimento, o híbrido de meloeiro 'Bônus II' foi enxertado nos porta-enxertos 'Dinero' e 'Strong Tosa', inoculadas com o isolado Dbr 37 do fungo e submetidas a diferentes concentrações de potássio $(0 ; 62,5 ; 125$; 187,$5 ; 250 \mathrm{~m} \mathrm{~L}^{-1}$ ), tanto plantas enxertadas como pé-franco. As plantas do híbrido 'Bônus II' enxertadas foram resistentes ao fungo e as pé-franco susceptíveis. As concentrações de potássio não influenciaram no tamanho da lesão e na sobrevivência das plantas, porém influenciaram na condutância estomática e transpiração das plantas.

Palavras chave: Plantas enxertadas, isolados, nutrição, resistentes, lesão, C. melo var. reticulatus Naud 


\section{Rootstocks, potassium concentrations in the resistance to Didymella bryoniae and physiological relationship of melon. Botucatu, 2010. 73 p.}

Dissertação (Mestrado em Agronomia) - Faculdade de Ciências Agronômicas. Universidade Estadual Paulista.

Author: EDVAR DE SOUSA DA SILVA

Adviser: RUMY GOTO

Co-Adviser: EDSON LUIZ FURTADO

DIRCEU MAXIMINO FERNANDES

\section{SUMMARY}

Chemical control of the fungus Didymella bryoniae, causal agent of gummy stem blight of melon, is frequently inefficient. Alternative methods as grafting on resistant rootstocks and nutrition handling must be studied. Different rootstocks and potassium concentrations were tested to control the disease on net melon grown under plastic house conditions. In a first experiment four rootstocks (melon 'Dinero', watermelon 'Ojakkyo', squash 'Strong Tosa' and calabash 'TI-191') were tested for resistance inoculated by disks mycelium (7 mm diameter) with four isolates ( Dbr 34, Dbr 36, Dbr 37 and Dbr 39) of $D$. bryoniae in stem previously injured. Based on lesion size 'Dinero' proved to be susceptible to the fungus, 'Strong Tosa' moderately resistant and 'Ojakkyo' and 'TI-191' resistant and the isolated Dbr 37 proved more aggressive among isolates. In a second experiment hybrid net melon 'Bonus II' was grafted on rootstocks 'Dinero' and 'Strong Tosa', inoculated with isolate Dbr 37 of the fungus and submitted to different potassium concentration $(0 ; 62,5 ; 125$; 187,5; $250 \mathrm{mg} \mathrm{L}^{-1}$ ), inoculated both grafted plants as non grafted. Grafted plants of 'Bonus II' were resistant to the fungus and the non grafted ones susceptible. Potassium concentrations did not influenced size of the lesion on the stem and also in the plants survival, however influence on stomatal conductance and transpiration plants.

Keywords: Grafted plants, isolates, nutrition, resistant, lesion, C. melo var. reticulatus Naud 


\section{INTRODUÇÃO}

Dentre várias doenças do meloeiro rendilhado em ambiente protegido, o crestamento gomoso ou cancro da haste causado pelo fungo Didymella bryoniae tem sido considerada uma das mais importantes.

O controle químico utilizado tem freqüentemente apresentado baixa eficiência, porém alternativas como desinfecção de tesouras de poda, evitar construir o ambiente protegido em locais de baixadas e controle racional da irrigação têm obtido sucesso.

Dentre as alternativas de controle, a utilização da enxertia em hortaliças fruto como nos cultivos de pimenteiro, tomateiro, berinjeleira, pepineiro e meloeiro têm possibilitado contornar problemas de patógenos. Isto pode ser uma alternativa de controle do fungo Didymella bryoniae que apesar de não considerado como um patógeno de solo sobrevive em restos de plantas no solo.

Outra alternativa para controle de doenças de plantas tem sido a manipulação da nutrição mineral para, porém o estudo da interação da nutrição sobre as doenças tem sido pouco explorado e muitas vezes os resultados são contraditórios ou as interpretações equivocadas, mas sabe-se da importância da nutrição na manifestação ou não das doenças.

O efeito da nutrição na intensidade de doenças é conhecido para certo número de plantas cultivadas sob condições controladas, porém existem poucos estudos relacionados à cultura do meloeiro, principalmente do tipo rendilhado (net). 
Este trabalho teve como objetivo avaliar porta-enxertos e concentrações de potássio na resistência de meloeiro rendilhado a Didymella bryoniae. 


\section{REVISÃO DE LITERATURA}

\subsection{A cultura do meloeiro rendilhado}

O meloeiro, cujo nome cientifico é Cucumis melo L. pertence à família Cucurbitaceae. É do tipo fanerógma por reproduzisse através de sementes e subtipo das angiospermas, pois o gineceu possui ovário e estigma, e as sementes se localizam dentro do fruto. Pertence a classe das dicotiledôneas, pois suas sementes dispõem de dois cotilédones, e subclasse das metaclamídeas, pois apresenta corola com as partes soldadas em pelos menos uma base, com flores pentâmeras e com estames inclusos. Os frutos são bagas grandes de tamanho (de $100 \mathrm{~g}$ até vários quilogramas) e formato (achatado, redondo ou cilíndrico) variados, com pericarpo resistente e placenta carnosa (MÁRMOL, s.d.).

O meloeiro é uma planta herbácea, anual, rasteira ou trepadora que facilita o tutoramento apropriado mediante uso de tutores simples de 20 a $30 \mathrm{~cm}$ de comprimento que se originam nas axilas das folhas, juntos aos brotos em formação. Devido o cultivo intensivo e sob ambiente protegido (MÁRMOL, s.d.).

A planta de meloeiro durante seu crescimento e desenvolvimento requer um teor de umidade do ambiente de até $75 \%$, que influenciam nos processos de transpiração, fecundação, floração e a não propagação de doenças e é menos exigente que as demais cucurbitáceas. Em relação ao solo também necessita de um teor de umidade ótimo, pois através das raízes, as plantas absorvem a maioria dos elementos nutritivos dissolvidos em 
água. Também necessita certa temperatura, que é variável em cada fase de desenvolvimento da planta. O calor do solo permite que se induzam funções vitais para a planta e facilite o desenvolvimento da vida microbiana (MÁRMOL, s.d.).

A luminosidade e temperatura são importantes, de tal forma que os frutos de variedades tipo Gália/Cantaloupes são influenciados pela intensidade da radiação e das temperaturas. Por outro lado, a falta de luz e temperaturas baixas pode endurecer as plantas e retardar o desenvolvimento (MÁRMOL, s.d.).

Originário da África e da Ásia (BRANDÃO FILHO \& VASCONCELLOS, 1998), e para Filgueira (2007) especificamente, dos quentes vales do Irã e do Noroeste da Índia. Cultivado na Europa e Ásia desde os primórdios da Era Cristã. No Brasil, foi introduzido pelos imigrantes europeus no século XIX, dando início à expansão da cultura nas regiões Sul e Sudeste (HUCITEC, 1992).

Nos últimos anos, o Brasil deixou de ser importador de melão europeu e passou a ser exportador. Este fato deve-se à produção do melão no nordeste brasileiro, onde existem condições climáticas favoráveis ao seu cultivo o ano todo, contribuindo para uma alta produtividade e qualidade e, ainda, favorecendo a aparência e o sabor da fruta (MOREIRA, et al., 2009).

O nordeste é a principal região produtora de melão, contribuindo com mais de $90 \%$ da produção nacional (NAKAMEA, 2004). No estado de São Paulo, a área plantada em 2006 foi 110 ha com uma produção de 2.415 toneladas de melão, correspondendo à produtividade de 22 t/ha (CAMARGO et al., 2008).

$\mathrm{Na}$ literatura encontra-se pouca informação relativa à quantidade de área plantada com meloeiro do grupo reticulatus no Brasil, Cucumis melo var. reticulatus Naud. (WHITAKER \& DAVIS, 1962), uma vez que a maior expressividade de plantio ocorre para o melão do grupo inodorus. (VARGAS et al., 2008).

Os melões do tipo amarelo são os mais plantados no Brasil, chegando a ocupar $70 \%$ das áreas com a cultura, embora esteja ocorrendo gradativo aumento no cultivo de melões, considerados como nobres, nas últimas safras, estando entre estes os rendilhados (BRASIL, 2003). Estes melões apresentam vantagens comerciais em relação ao tipo amarelo, como maior preferência do consumidor, boa cotação comercial e cultivo em pequenas áreas com boa lucratividade (RIZZO, 2004). 
As condições climáticas favoráveis e a evolução das técnicas de cultivo têm possibilitado a melhoria da qualidade da produção brasileira de melão. Além disso, a produção na época de entressafra de outros países também vem facilitando a ampliação do mercado nacional no exterior (NEGREIROS et al., 2003).

Com a consolidação da produção de hortaliças em casa de vegetação, o cultivo do meloeiro nobre do tipo rendilhado recebeu maior atenção dos produtores, especialmente nos estados de São Paulo e Paraná, como opção rentável no cultivo protegido (PURQUERIO, 2002; MOREIRA et al., 2009). Esse sistema se expandiu a partir de 1990, com a possibilidade de exportação e a perspectiva de novos nichos de mercado, com a expansão das grandes redes de supermercados no país. Dessa forma, o meloeiro está sofrendo uma sensível expansão de cultivo nesse sistema, com predominância dos melões do grupo reticulatus.

O meloeiro do tipo rendilhado, como os híbridos Bônus II e Sunrise, é uma das culturas mais importantes para ser cultivado em condições de ambiente protegido no norte do estado de Paraná. Nesse tipo de melão têm ocorrido grandes problemas com doenças, com freqüentes danos significativos e, algumas vezes, com perdas totais para a cultura (VIDA et al., 1993; 1994). Neste contexto, a podridão gomosa, causada por Didymella bryoniae Auersew, tem sido umas das mais importantes doenças da cultura.

\subsection{Didymella bryoniae}

\subsubsection{Sintomatologia e epidemiologia}

O fungo Didymella bryoniae ataca todos os órgãos aéreos da planta em qualquer estádio de desenvolvimento. Os sintomas nas folhas são manchas pardas circulares, cujo diâmetro pode variar de alguns milímetros a vários centímetros. Em estádio mais avançado, verificam-se numerosos pontos negros que são os corpos de frutificação do fungo (KIMATI et al, 2005).

Embora de grande importância, esta doença tem sido pouco estudada, com restrito número de trabalhos publicados. Dusi (1991), Kurozawa \& Pavan (2005) citam que, no Brasil, a podridão gomosa em cultivo convencional apresenta-se como doença de 
grande importância para a cultura do meloeiro. Vida et al. (1997) relataram que em cultivo protegido, quando as infecções ocorrem no caule, abaixo da inserção dos frutos, verificam-se sintomas de necrosamento que se estende longitudinal e transversalmente, com conseqüente murcha e morte da planta. Nessa condição, geralmente, as perdas são totais, uma vez que os frutos não terão nenhum valor comercial.

O fungo causa infecção durante períodos de temperaturas moderadas 20 a $28^{\circ} \mathrm{C}$ e molhamento foliar por mais de uma hora; ambientes protegidos com temperaturas noturnas frias e alta umidade também favorecem sua disseminação; além de sobreviver em resto de cultura, plantas daninhas e sementes contaminadas.

Quanto ao modo de penetração do patógeno nos tecidos da planta hospedeira, existe discordância entre os pesquisadores. Chiu \& Walker (1949b), citados por Tsutsumi, (1995) mencionam que a penetração nas folhas se dá diretamente ou através dos espaços intracelulares ao redor da célula basal de um tricoma desgastado. No caule e no colo ocorre, aparentemente, através de ferimentos ou por extensão de lesões nos cotilédones e nas folhas.

Neergaard (1989b), estudando plantas de pepino, concluiu que normalmente $D$. bryoniae não invade a planta através da penetração pela cutícula, mas através dos estômatos e ferimentos. Ferimentos e injúrias causados por insetos também são importantes portas de entrada.

O cancro-da-haste, podridão da micosferela ou gomosa, causado por D. bryoniae, têm causado sérios problemas ao meloeiro rendilhado (GUALBERTO et al., 2001) e vem aumentando a importância nos cultivos protegidos com filme plástico de polietileno de baixa densidade (PEBD), causando perdas estimadas em até 56,3\% no Brasil (VIDA et al., 1996).

\subsubsection{Controle}

O controle do fungo $D$. bryoniae pode ser feito através de práticas como: manejo de irrigação, rotação de cultura (18 meses), utilização de sementes sadias, casa de vegetação ventilada e isenta de frutos afetados. Para o melão, o controle químico, tem sido ineficiente, principalmente em condições de alta umidade e temperatura, embora 
experimentalmente a aplicação de benomyl e iprodione, via solo, tenha apresentado bons resultados (KIMATI et al., 2005).

A circulação de ar na estufa é importante para a retirada do excesso de umidade no ar, promover a evaporação da água livre da superfície foliar mais rapidamente e retirar o excesso de calor, pois a persistência de água livre nas plantas e a alta umidade favorecem a penetração do fungo D. Bryoniae (VIDA et al., 2004a).

O local de instalação do ambiente protegido também é primordial, quando possível, não se deve instalar o ambiente protegido em locais de baixada, onde predominam fatores ambientais que poderão influenciar, favoravelmente, o estabelecimento de doenças e, conseqüentemente, o manejo do ambiente protegido. As baixadas estão sujeitas à ocorrência de nevoeiros, ao acúmulo de ar frio, a geadas e ao acúmulo de água no solo (ZAMBOLIM et al. 2000) e, esses fatores favorecem ao fungo D. bryoniae.

As ferramentas utilizadas nas operações de podas e desbrotas em melão rendilhado cultivado em ambiente protegido na região norte do estado do Paraná é o principal agente disseminador de D. bryoniae e a desinfecção dessas ferramentas com hipoclorito de sódio (2\%) é uma alternativa eficiente na redução da disseminação desse fungo, responsável pelo crestamento gomoso (VIDA et al., 2004b).

\subsection{Nutrição mineral e resistência a doenças}

Para o crescimento e desenvolvimento da planta, a nutrição mineral é um fator primordial. A proporção dos elementos minerais requerida pelas plantas pode ser fortemente determinada pela família, espécie, pelo estádio de desenvolvimento ou pelo órgão da planta. Entretanto, para a planta atingir um metabolismo balanceado, uma alta produção de matéria seca e desenvolvimento adequado existem dois fatores importantes: quantidades suficientes e proporções balanceadas de nutrientes (LARCHER, 2000). Quando o suprimento de nutrientes para as plantas é inadequado, desenvolver-se-ão desordens fisiológicas manifestadas por sintomas característicos de deficiência ou toxidez. Estes sintomas dependem da função ou funções do nutriente e de sua capacidade de movimentação no floema e xilema (ROBERTS \& HARMON, 1992; LARCHER, 2000). 
A nutrição mineral além de atuar no crescimento e produção, pode também influenciar de forma secundária, levando a modificações no crescimento, morfologia, anatomia e na composição química das plantas. Com isso, os nutrientes minerais podem aumentar ou diminuir a resistência das plantas a patógenos, e a resistência pode ser conferida devido a modificações anatômicas, como espessamento das células da epiderme, lignificação, e ainda atuar nas propriedades fisiológicas e bioquímicas, pela produção de substâncias inibidoras e repelentes (ZAMBOLIM \& VENTURA, 1993). Os mesmos autores citam que os efeitos da nutrição mineral são pequenos quando o hospedeiro é totalmente resistente ou suscetível, mas bastante grandes em materiais genéticos moderadamente suscetíveis ou "parcialmente" resistentes.

A nutrição mineral é um fator ambiental facilmente manipulado e utilizado como um complemento no controle às doenças (MARSCHNER, 1995). Alguns nutrientes fortalecem os tecidos, como o fósforo e o potássio, enquanto outros tomam os tecidos mais tenros, mais sensíveis aos fítopatógenos como, por exemplo, o nitrogênio. O fósforo pode reduzir a fase vegetativa da planta e com isso reduzir o período de suscetibilidade às ferrugens. Enquanto altos níveis de nitrogênio aumentam o período vegetativo e retardam a senescência natural, alongando o período em que o hospedeiro pode ser infectado pelo patógeno.

As plantas desequilibradas nutricionalmente são mais suscetíveis do que aquelas corretamente nutridas; a forma como os nutrientes estão disponíveis às plantas influencia o seu efeito sobre as doenças (ZAMBOLIM \& VENTURA, 1993). O uso e o manejo dos nutrientes, de forma equilibrada, têm demonstrado ser uma alternativa válida no controle às moléstias das plantas (MATIELLO et al., 1997).

O estudo da interação da nutrição sobre as doenças das plantas têm sido pouco explorados e muitas vezes os resultados são contraditórios ou com interpretações equivocados, mas sabe-se da importância da nutrição na manifestação ou não das doenças (WALTERS, D.R \& BINGHAM, 2007). A limitação da sua utilização tem sido em relação à manipulação da nutrição destas culturas para melhorar o controle de doenças.

O efeito da nutrição na intensidade de doenças é conhecido para certo número de plantas cultivadas sob condições controladas, porém existem poucos estudos relacionados a cultura do meloeiro, principalmente do tipo rendilhado (net). 


\subsection{Relação do potássio com doenças e pragas}

Na maioria das células, o potássio $(\mathrm{K})$ apresenta maior concentração interna quanto maior permeabilidade na membrana, de forma que o potencial de difusão pode aproximar Ek, o potencial de Nernst para o $\mathrm{K}^{+}$(TAIZ e ZEIGER, 2004).

A abertura e fechamento dos estômatos é um efeito altamente específico do potássio junto com a luz. Faltando K, os estômatos não se abrem regularmente, há menor entrada de gás carbônico e, portanto, menor intensidade fotossintética (MALAVOLTA, 1980).

$\mathrm{Na}$ cultura do pepineiro foi observado maiores concentrações de potássio no caule e nos ramos em relação à folha (SOLIS et al., 1983, citados por CAÑIZARES 2001). Os caules de plantas deficientes em potássio podem ser delgados e fracos, com regiões internodais anormalmente curtas (TAIZ \& ZEIGER, 2004).

O K é um nutriente com expressivo efeito na qualidade produtiva das culturas. Embora muitos processos pelos quais a nutrição potássica influencia a qualidade da cultura, não estejam completamente compreendidos, mas tem-se verificado que ela promove estímulos de síntese de carboidratos, aumento da espessura da casca, o tamanho e a acidez dos frutos, conferindo melhor qualidade física e melhor aparência ao produto, podendo estar relacionado como o sabor dos frutos e com maior tolerância da cultura ao ataque de certas doenças e pragas, além de aumentar a resistência do fruto ao transporte e ao armazenamento (PRETY, 1982; FERREIRA e PEDROSA, 1982; FAQUIM, 1994; MENEZES et al., 2000, citados por DUTRA, 2005).

$\mathrm{O}$ efeito do K é explicado por mudanças na morfologia e fisiologia do hospedeiro. Pode ainda influenciar outros fatores bióticos que afetam a relação entre o parasita e o hospedeiro (MALAVOLTA, 2006).

A literatura registra 2449 indicações sobre as relações entre K e sanidade da planta com relação a doenças e pragas, destacando-se a maior relação com as doenças fúngicas (PERRENOUD, 1990; MALAVOLTA, 2006), conforme Tabela 1. 
Tabela 1. Efeitos de $\mathrm{K}$ na incidência de doenças (MALAVOLTA, 2006). Número e (porcentagem) de indicações

\begin{tabular}{lcccc}
\hline \multicolumn{1}{c}{ Parasita } & Total & $\begin{array}{c}\text { Diminuição } \\
\text { incidência }\end{array}$ & $\begin{array}{c}\text { Aumento } \\
\text { incidência }\end{array}$ & Sem alterações \\
\hline Fungos & 1549 & $1080(70)$ & $357(23)$ & $112(7)$ \\
Insetos e Ácaros & 459 & $290(63)$ & $130(28)$ & $39(9)$ \\
Nematóides & 111 & $37(33)$ & $70(63)$ & $4(4)$ \\
Vírus & 186 & $76(41)$ & $96(52)$ & $14(7)$ \\
Bactérias & 144 & $99(69)$ & $31(21)$ & $14(10)$ \\
\hline Total & 2449 & $1582(68)$ & $684(28)$ & $185(7)$ \\
\hline
\end{tabular}

Um levantamento semelhante foi apresentado em um capítulo de revisão recente por Prabhu et al. (2007) em que o efeito de K na ocorrência de doenças foi obtido em mais de 200 estudos e foi classificado como 'maior', 'diminuiu', 'sem efeito' ou 'efeito variável', sendo que a aplicação de K mostrou-se mais benéfica para a resistência contra fungos em 110 dos 155 casos encontrando uma diminuição da doença fúngica com doses crescentes de K. Em torno de 20 casos houve aumento da incidência, 15 casos mostraram nenhum efeito e 10 casos com efeito variável. Novamente, a diminuição da incidência por K foi menos acentuada em bactérias (de 23 casos: 18 mostraram decréscimo e 5 mostraram aumento) e vírus (de 15 casos, 9 mostraram diminuir, em 4 houve aumento e 2 casos não apresentaram nenhum efeito).

São evidentes as existências de correlações entre o estado nutricional de $\mathrm{K}$ da planta e incidência de doenças, mas também há a necessidade de estudos relacionados aos efeitos de $\mathrm{K}$ sobre processos fisiológicos, metabólicos e hormonais que tendem a ser cruciais para a susceptibilidade e sensibilidade de plantas aos agentes patogênicos e insetos, para melhor estabelecer estas correlações (AMTMANN et al., 2008).

$\mathrm{O} \mathrm{K}$ pode manifestar o seu efeito sobre o hospedeiro de diversas maneiras (MALAVOLTA, 2006):

1. Número, desenvolvimento, sobrevivência, vigor e duração do ciclo do agente causal da doença;

2. Suprimentos de nutrientes do hospedeiro para o patógeno quando há deficiência do elemento, com ou sem mudança no hábito do crescimento do primeiro; 
3. Dificuldade na infecção através da formação de barreiras representadas pela estrutura da parede celular;

4. Recuperação do tecido lesado após a infecção.

No nível molecular Malavolta, (1998) resume as interações entre o potássio e o patógeno, da seguinte forma:

1. Deficiência: há menor formação de parede celular; acúmulo de carboidratos solúveis (= menor síntese de amido, celulose, por exemplo), de aminoácidos livres, isto é, menos proteínas (estruturas, enzimáticas, protetoras); menor proteção de fenóis e alexinas inibidoras do patógeno; desequilíbrio na relação $\mathrm{N} / \mathrm{K}$ igual a excesso de $\mathrm{N}$;

2. Excesso: desequilíbrio nas relações $\mathrm{K} / \mathrm{Ca}$ e $\mathrm{K} / \mathrm{Mg}$; menor formação da lamela média da parede por falta de cálcio; quebra do funcionamento normal da membrana plasmática, vazamentos de solutos; distúrbios na formação de proteínas e no uso da energia do ATP para sínteses em geral.

Zambolim (1998) apresentou uma lista do efeito do K sobre diversos tipos de doenças das quais estão destacadas algumas espécies de cucurbitáceas conforme a Tabela 2.

Tabela 2. Efeito do K sobre doenças em algumas cucurbitáceas.

\begin{tabular}{lccc}
\hline \multicolumn{1}{c}{ Patógeno } & Hospedeiro & Aumento & Diminuição \\
\hline Sclerotinia sclerotiorum & Abóbora & & $\mathrm{X}$ \\
Pseudomonas syringae pv. lachrymans & Pepino & & $\mathrm{X}$ \\
Erwinia tracheiphila & Pepino & $\mathrm{X}$ & \\
Fusarium oxysporum f. sp. niveum & Melão & $\mathrm{X}$ & \\
\hline
\end{tabular}

Ao contrário das respostas ao $\mathrm{N}$, altas doses de $\mathrm{K}$ aplicadas às plantas causam sempre maior resistência às doenças, independentemente do tipo de patógeno. O suprimento de potássico pode neutralizar os efeitos negativos de uma alta dose de $\mathrm{N}$ na resistência a estresses, como por exemplo, resistência às doenças (HÖMHELD, 2005).

$\mathrm{O}$ alto suprimento de $\mathrm{N}$ (ou baixa relação $\mathrm{K} / \mathrm{N}$ ) faz com que constituintes solúveis de baixo peso molecular (como aminoácidos e açúcares), que são substratos nutricionais de pragas e doenças, sejam metabolizados em compostos de alto peso 
molecular (como proteínas, amido e celulose), com isto, aumenta a suscetibilidade da planta aos patógenos e às pragas (MARSCHNER, 1995; HÖMHELD, 2005).

A possível diminuição do $\mathrm{pH}$ da rizosfera com $\mathrm{K}_{2} \mathrm{SO}_{4}$ ou com $\mathrm{N}-\mathrm{NH}_{4}{ }^{+}$ estabilizado com $\mathrm{KCl}$ que, por conseqüência, melhora a aquisição de $\mathrm{Mn}$, Zn e Si pelas plantas aumenta a resistência a doenças. Zhang, (2004) citado por Hömheld, (2005) comparou duas fontes de $\mathrm{N}: \mathrm{N}_{-} \mathrm{NO}_{3}{ }^{-}$e N-NH${ }_{4}{ }^{+}$tratado com ENTEC, um inibidor de nitrificação, e demonstrou este aumento na aquisição de $\mathrm{Mn}, \mathrm{Zn}$, e Si pelas plantas, destacando aumento significativo na concentração de $\mathrm{Si}$, que segundo a literatura tem papel importante na resistência às doenças.

Destaca-se também a importância que o adequado suprimento de potássio aumenta a taxa de infecção com micorriza, a qual também aumenta a resistência às doenças. Na Alemanha é muito comum a doença do replante da videira que pode ser controlada pela inoculação com micorrizas, as quais, por sua vez, são estimuladas por adequado suprimento potássico ou balanceada relação K/N (HÖMHELD, 2005).

\subsection{Enxertia em hortaliças}

O início da enxertia em hortaliças ocorreu em melancia (Citrullus lanatus) no Japão e na Korea em 1920. Em berinjela começou em 1950. O objetivo inicial foi controlar de forma preventiva, a doença ocasionada por Fusarium oxysporum, em melancia (YAMAKAWA, 1982).

A partir de 1970, a enxertia em hortaliças tem sido muito valorizada, desenvolvendo-se nessas três décadas vários trabalhos objetivando o controle de patógenos de solo, modificação da expressão sexual, compatibilidade, nutrição, desenvolvimento, produção e qualidade de frutos (CAÑIZARES, 2001), como por exemplo, o controle de Fusarium oxysporum, tolerância a temperaturas baixas e desordens fisiológicas na cultura do meloeiro (ODA, 1995).

A utilização da enxertia em hortaliças pode ser uma alternativa para contornar problemas de doenças de solo e salinização no ambiente protegido, em curto prazo e em alguns casos, com menores custos. No Japão, essa prática já é utilizada com sucesso, sendo $16 \%$ em tomateiros e $99 \%$ em melancia (KAWAIDE, 1985). 
A utilização da enxertia é mais interessante que outras formas de controle isolado ou conjunto de doenças, podendo proporcionar tolerância à temperaturas adversas, à salinidade do solo, aumentar o vigor, reduzir desordens fisiológicas das plantas e resultar na produção de frutos de melhor qualidade (GOTO et al., 2003).

Segundo Hoyos (2000) no controle de patógenos, a utilização da

enxertia é mais interessante que outras formas de controle, como solarização, emprego de vapor de água, pulverizações de produtos químicos e até mesmo opção pela hidroponia, isso porque o uso da enxertia não exige uma mudança drástica no manejo da cultura.

\subsection{Enxertia e Didymella bryoniae}

A utilização da enxertia em hortaliças fruto como nas culturas de pimenteiro, tomateiro, berinjeleira, pepineiro e meloeiro têm sido utilizadas para contornar problemas de patógenos de solo.

Trionfetti-Nisini et al. (2000) afirmam que a utilização de meloeiro enxertado em genótipos selecionados, embora considerado um processo caro, representa potencialmente um método eficaz para aumentar a produção de cultivares ou híbridos de meloeiro, importantes economicamente e sensíveis à doenças causadas pelos fungos $D$. bryoniae e raça 1 e 2 de $F$. oxysporum f. sp. melonis, evitando a utilização da esterilização do solo e fungicidas. Este fato foi observado quando avaliaram os porta-enxertos comerciais 'ELSI', 'ES 99-13', 'RS 841' de melão quanto à resistência a $D$. bryoniae e raça 1 e 2 de $F$. oxysporum f. sp. melonis em casa de vegetação. Os autores citados constataram que os mesmos apresentaram um grau elevado de resistência ao fungo.

Crino et al. (2007) afirmam que a utilização de porta-enxertos resistentes a algumas doenças de solo na cultura do meloeiro pode ser uma alternativa de controle do fungo $D$. bryoniae. Os autores avaliaram o híbrido Incas enxertado nos portaenxertos comerciais: 'RS 841', '360 P', 'ES 99-13', 'Elsi' (Cucurbita maxima Duchesne x Cucurbita moschata Duchesne) e 'Belimo', 'Energia', 'Griffin', 'ES liscio' (genótipos de Cucumis melo) quanto a sua resistência a raça 1,2 de Fusarium oxysporum f. sp. melonis (FOM) e D. bryoniae. Observaram que as plantas enxertadas em 'RS 841', '360 P', 'ES 99-13' e 'Elsi' foram altamente resistentes tanto para a raça 1,2 de FOM (sobrevivência de $100 \%$ ) e a 
D. bryoniae (poucas lesões e folhas com baixo índice de doença), deferindo claramente das enxertadas em 'Belimo', 'Energia', 'Griffin', 'ES liscio' e o controle Incas na forma de pé-franco (não enxertado).

Ito et al. (2006) estudando genótipos de abóbora e maxixe inoculados com o fungo D. bryoniae, mostram que os mesmos foram resistentes. Os mesmos autores ao fazerem seleção de porta enxertos resistentes à $D$. bryoniae e avaliarem seus efeitos na produtividade de melão rendilhado, testaram 17 genótipos de cucurbitáceas, dentre estes, apenas a melancia-'Charleston-Gray’ e melão-'Redondo-Amarelo’ foram suscetíveis ao patógeno e, para efeitos da produtividade, foram enxertados sobre os genótipos resistentes, melão-rendilhado 'Bônus $\mathrm{n}^{\circ}$ 2', e o porta enxerto Benincasa hispida foi mais indicado para melão- rendilhado (ITO et al, 2009). 


\section{MATERIAL E MÉTODOS}

\subsection{Local dos experimentos}

Os dois experimentos foram conduzidos respectivamente de setembro a dezembro de 2008 e maio a setembro de 2009, em vasos sob ambiente protegido, estrutura tipo arco, de $10 \times 40 \mathrm{~m}$ coberto por filme de polietileno de baixa densidade (PEBD) transparente de $100 \mu \mathrm{m}$ de espessura, no município de São Manuel, SP, em área da Fazenda Experimental de Ensino, Pesquisa e Produção, pertencente à Faculdade de Ciências Agronômicas (FCA) da Universidade Estadual Paulista (UNESP) de Botucatu, nas coordenadas geográficas aproximadas de $22^{\circ} 44^{\prime}$ latitude sul e $48^{\circ} 34^{\prime}$ de longitude oeste, com altitude em torno de $750 \mathrm{~m}$. O clima local é do tipo mesotérmico, subtropical úmido (Cfa) e a precipitação média anual é de $1.445 \mathrm{~mm}$, sendo a temperatura média anual de $21^{\circ} \mathrm{C}$, com a temperatura do mês mais quente $23,8^{\circ} \mathrm{C}$ e do mês mais frio $17,5^{\circ} \mathrm{C}$.

\subsection{Reação de porta-enxertos de meloeiro a isolados de Didymella bryoniae}

\subsubsection{Delineamento experimental}

O delineamento experimental foi em blocos casualizados em esquema fatorial 4 x 5 com seis repetições. Os tratamentos resultaram da combinação de quatro porta- 
enxertos de meloeiro: 'Dinero' (melão), 'Ojakkyo' (melancia selvagem), 'Strong Tosa' (abóbora) e 'Calabash TI-191' (cabaça) e quatro diferentes isolados de D. bryoniae ( Dbr 34, Dbr 36, Dbr 37 e Dbr 39 provindos das regiões sudeste, norte, nordeste e sul do Brasil, respectivamente) e um tratamento controle (somente com o ferimento do palito). Cada parcela foi constituída por uma linha de $4 \mathrm{~m}$, com oito plantas. $\mathrm{O}$ espaçamento adotado foi de $1,0 \times 0,5$ m.

\subsubsection{Caracterização do solo}

O solo utilizado nos dois experimentos foi coletado em barranco localizado na Fazenda Experimental São Manuel, o qual foi classificado como Latossolo Vermelho Escuro, fase arenosa, segundo Espíndola et al. (1974), denominado pela nomenclatura do Sistema Brasileiro de Classificação de solos como Latossolo Vermelho Distrófico Típico (EMBRAPA, 1999).

Tabela 3. Características físicas do solo utilizado no experimento. São Manuel-SP - FEPP UNESP/FCA, 2008.

\begin{tabular}{cccccc|c|c}
\hline AG & AF & Areia/T & Argila & Silte & Arg. Nat. & Umidade \\
$\%$ & Textura do solo \\
\cline { 1 - 4 } & \multicolumn{9}{c}{$\mathrm{g} / \mathrm{kg}$} & & & ---- & \\
\hline------ & 770 & 191 & 39 & -- & Média \\
\hline
\end{tabular}

As adubações foram realizadas de acordo com resultados da análise (Tabela 4).

Tabela 4. Características químicas do solo utilizado no experimento. São Manuel-SP - FEPP UNESP/FCA, 2008.

\begin{tabular}{|c|c|c|c|c|c|c|c|c|c|}
\hline pH & M.O. & $\mathbf{P}_{\text {resina }}$ & $\mathbf{H}+\mathbf{A l}$ & $\mathbf{K}$ & Ca & Mg & SB & CTC & V\% \\
\hline $\mathrm{CaCl}_{2}$ & $\mathrm{~g} / \mathrm{dm}^{3}$ & $\mathrm{mg} / \mathrm{dm}^{3}$ & - & - & - & $\mathrm{mmol}_{\mathrm{d}} / \mathrm{dm}^{3}$ & 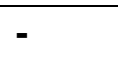 & - & - \\
\hline 4,4 & 4 & 3 & 22 & 0,4 & 5 & 2 & 7 & 29 & 25 \\
\hline Boro & \multicolumn{2}{|c|}{ Cobre } & \multicolumn{3}{|c|}{$\begin{array}{l}\text { Ferro } \\
\mathrm{mg} / \mathrm{dm}^{3}\end{array}$} & & Inganê: & \multicolumn{2}{|c|}{ Zinco } \\
\hline 0,17 & \multicolumn{2}{|c|}{0,4} & \multicolumn{3}{|c|}{3} & & 0,9 & \multicolumn{2}{|c|}{0,1} \\
\hline
\end{tabular}




\subsubsection{Condução dos portas-enxertos}

As plantas foram conduzidas com haste única, sendo uma planta por vaso de $9 \mathrm{dm}^{3}$, verticalmente com $2 \mathrm{~m}$ de altura e desbrotando quando necessário, de acordo com o crescimento das plantas.

Os dados climáticos dos dois experimentos foram registrados no termo-higrômetro digital TFA, modelo 3030.15 com transmissor de temperatura através de sinais rádio de freqüência de $433 \mathrm{MHz}$.

\subsubsection{Obtenção dos Isolados}

Os isolados de $D$. bryoniae que foram utilizados são originários de quatro diferentes regiões do Brasil (Tabela 5).

Tabela 5. Isolados de D. bryoniae obtidos em diferentes regiões do Brasil.

\begin{tabular}{lll}
\hline $\mathbf{N}^{\circ}$ Isolado & Cultura & Local \\
\hline Dbr 34 & Melão & Bragança Paulista - SP \\
Dbr 36 & Melão & Porto Nacional - TO \\
Dbr 37 & Melão & Salvador - BA \\
Dbr 39 & Melão & Porto Alegre - RS \\
\hline
\end{tabular}

\subsubsection{Método de inoculação nos experimentos}

Antes da inoculação os isolados de D. bryoniae foram cultivados em meio de cultura BDA (batata desindrogenase agar) autoclavado a $120^{\circ} \mathrm{C}$ por 20 minutos a 1,5 atm. Para cada placa de Petri contendo $20 \mathrm{ml}$ do meio de cultura, foi repicado três discos de micélio de $7 \mathrm{~mm}$ de diâmetro durante sete dias, a $20^{\circ} \mathrm{C}$, no escuro.

A inoculação foi feita 20 dias após o transplante, pelo método do palito (VERZIGNASSI et al., 2004), fazendo a inserção de discos de micélio do patógeno de $7 \mathrm{~mm}$ 
no caule previamente ferido por um palito (Figura 1) (adaptado de TRIONFETTI-NISINI et al., 2000).

As plantas inoculadas ficaram em câmara úmida por 12 horas, sendo pulverizadas com água e cobertas com garrafas peti.

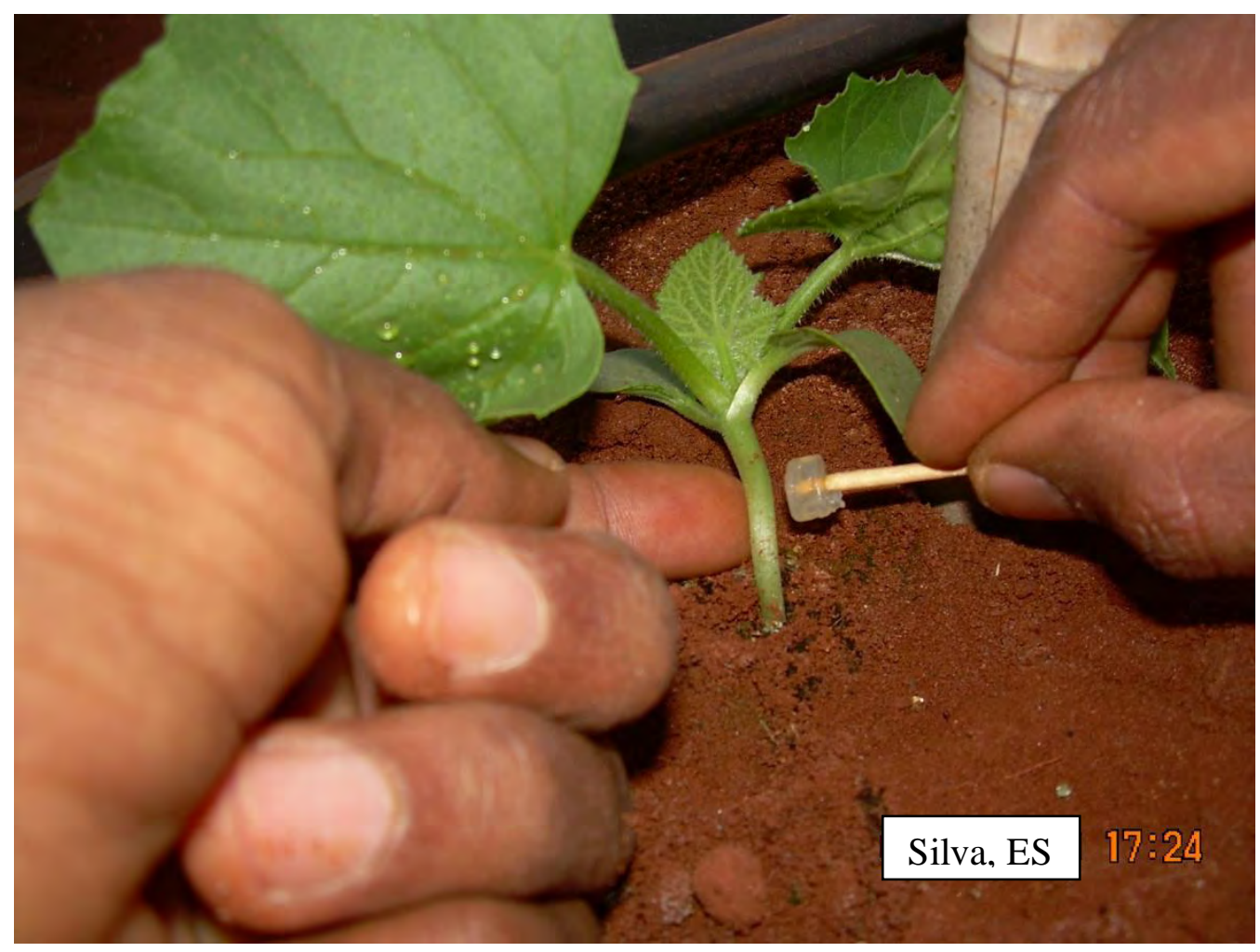

Figura 1. Método de inoculação com palito e disco de micélio do fungo.

\subsubsection{Avaliação das lesões nos experimentos}

As avaliações foram iniciadas sete dias após a inoculação dos isolados e a partir de então, efetuadas a cada sete dias. Os sintomas foram quantificados medindo-se o comprimento longitudinal e transversal da necrose resultado da colonização do patógeno. A intensidade da doença em cada planta foi o resultado da média aritmética simples das duas dimensões, constituindo o diâmetro médio da lesão (MARQUES et al., 2006). 


\subsection{Concentrações de potássio na resistência do meloeiro rendilhado híbrido 'Bônus II' enxertado e pé-franco a Didymella bryoniae}

\subsubsection{Delineamento experimental}

O delineamento experimental foi em blocos casualizados em esquema fatorial 3x5: plantas do híbrido de melão 'Bônus II' enxertadas nos porta-enxertos melão 'Dinero' e abóbora 'Strong Tosa', mais 'Bônus II' pé-franco e cinco concentrações de potássio: $0 ; 62,5 ; 125 ; 187,5 ; 250 \mathrm{mg} \mathrm{L}^{-1}$, totalizando 15 tratamentos.

Os dois porta-enxertos utilizados neste experimento foram os que apresentaram susceptibilidade e moderada resistência a $D$. bryoniae., de acordo com Zambolim \& Ventura (1993) sugerem ser mais interessante para avaliar quanto ao efeito da nutrição mineral em relação a doenças, cultivares moderadamente suscetíveis ou "parcialmente" resistentes, pois os efeitos são mais significativos, já que os efeitos da nutrição mineral são menores quando o hospedeiro é totalmente resistente ou suscetível.

O isolado Dbr 37 do fungo utilizado foi o que se mostrou mais agressivo aos portas-enxertos, segundo o item 4.1 (Reação de porta-enxertos de meloeiro a isolados de $D$. bryoniae). As concentrações de potássio: $0 ; 62,5 ; 125 ; 187,5 ; 250 \mathrm{mg} \mathrm{L}^{-1}$, representam respectivamente $0 \%, 50 \%$ abaixo, recomendada, 50\% acima e 100\% acima da concentração recomendada por Kano (2002) e fornecidas na forma de nitrato de potássio.

Em cada parcela foram cultivadas plantas do meloeiro (Cucumis melo var. reticulatus Naud.) tipo rendilhado (net), híbrido Bônus II enxertadas e não enxertadas, com uma fileira de plantas, espaçadas $1,0 \times 0,50 \mathrm{~m}$, totalizando 12 plantas por parcela, sendo seis plantas úteis, enquanto duas de cada extremo do tratamento dentro da parcela funcionaram como bordadura (Figura 2). 


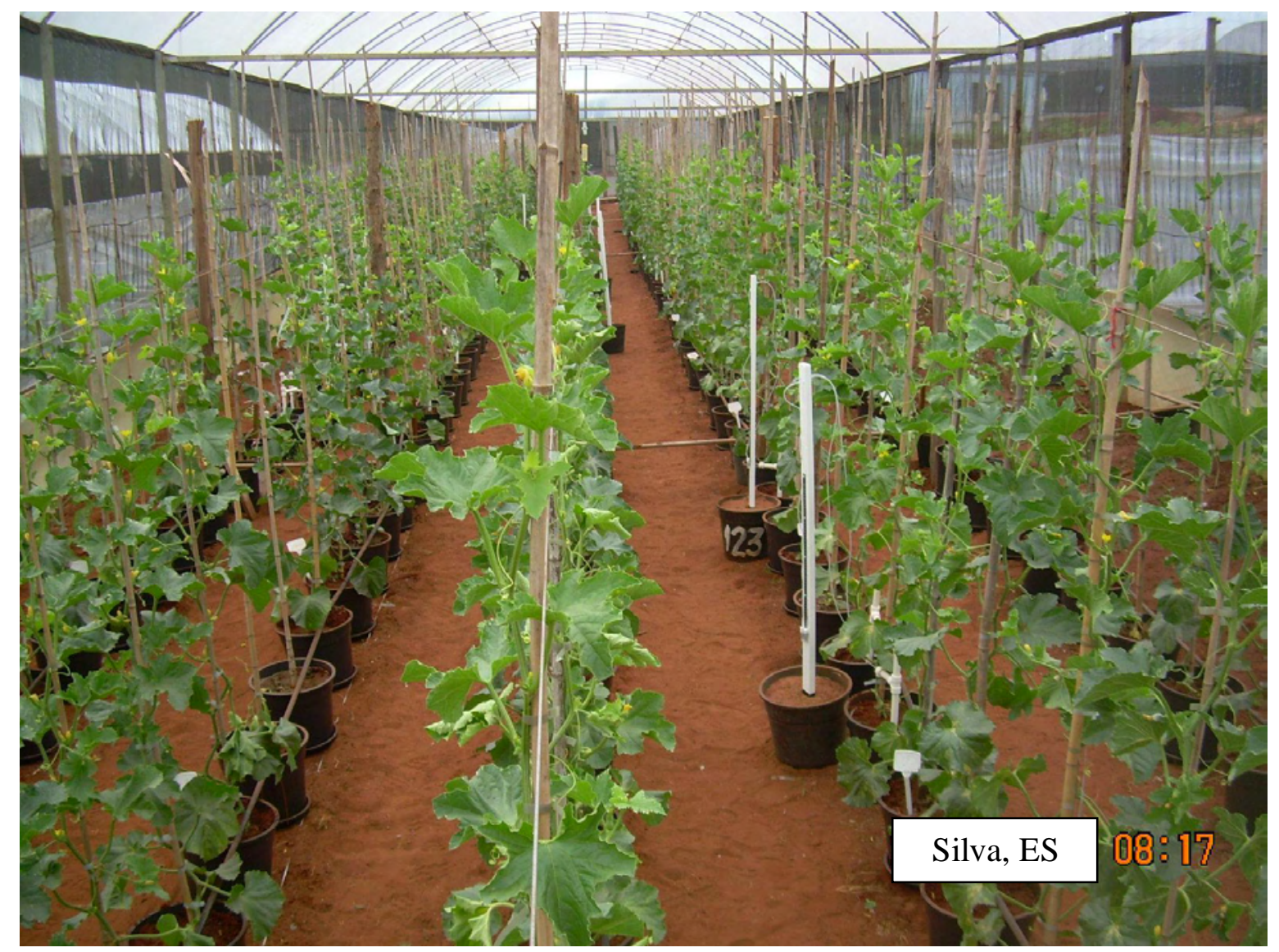

Figura 2: Vista geral do experimento no ambiente protegido 74 dias após transplante e 54 dias após inoculação. São Manuel-SP - FEPP - UNESP/FCA, 2009.

\subsubsection{Correção e adubação do solo}

De acordo com análise química do solo (Tabela 6), realizou-se correção da acidez, objetivando atingir $80 \%$ de $\mathrm{V}$, utilizando calcário dolomítco na proporção de $1,02 \mathrm{~g} \mathrm{~L}^{-1}$ de terra, acrescentando-se $160 \mathrm{~mL}_{\text {água }} \mathrm{L}^{-1}$ de terra para facilitar a reação do calcário e por fim deixando-se em incubação por 25 dias.

Após o período de incubação, realizou-se uma adubação básica de fósforo, antes do transplante das mudas, utilizando superfosfato triplo. 
Tabela 6. Características químicas do solo utilizado no experimento. São Manuel-SP - FEPP UNESP/FCA, 2009.

\begin{tabular}{|c|c|c|c|c|c|c|c|c|c|}
\hline pH & M.O. & $\mathbf{P}_{\text {resina }}$ & H+Al & $\mathbf{K}$ & $\mathbf{C a}$ & Mg & SB & CTC & V\% \\
\hline $\mathrm{CaCl}_{2}$ & $\mathrm{~g} / \mathrm{dm}^{3}$ & $\mathrm{mg} / \mathrm{dm}^{3}$ & - & - & - & $\mathrm{mmol}_{\mathrm{d}} / \mathrm{dm}^{3}$ & - & - & - \\
\hline 4,1 & 4 & 3 & 26 & 0,9 & 8 & 3 & 11 & 37 & 30 \\
\hline Boro & & pre & & $\begin{array}{l}\text { Ferro } \\
\mathrm{g} / \mathrm{dm}\end{array}$ & & -- & Iganê & & Zinco \\
\hline 0,3 & & & & 5 & & & 0,5 & & 0,7 \\
\hline
\end{tabular}

\subsubsection{Condução das plantas}

A semeadura dos porta-enxertos 'Dinero', 'Strong Tosa', híbrido Bônus II para enxertia e para uso como pé-franco foi feita respectivamente 32, 28, 28 e 16 dias antes do transplante das mudas para favorecer a compatibilidade dos porta-enxertos com o enxerto. O transplante foi realizado no dia 18/05/2009, 20 e 14 dias após a enxertia nos portaenxertos 'Dinero' e 'Strong Tosa' respectivamente.

As plantas foram conduzidas segundo Brandão Filho \& Vasconcellos (1998) com haste única, sendo uma planta por vaso de $14 \mathrm{dm}^{3}$ e, o tutoramento foi feito com estacas de bambu presas a arame localizado a $2 \mathrm{~m}$ do solo. Foram realizadas desbrotas até o $11^{\circ}$ nó, deixando-se as hastes secundárias nos entrenós $12^{\circ}, 13^{\circ}$ e $14^{\circ}$, pois, nestas apareceram as flores hermafroditas (futuros frutos) e, continuou-se a desbrota até o $20^{\circ}$ nó, deixando-se crescer também as hastes secundárias nos entrenós $21^{\circ}, 22^{\circ}$ e $23^{\circ}$ onde foi feito a capação da planta.

O controle de pragas e doenças foi realizado de acordo com a necessidade da cultura, pulverizando-se abamectina $18 \mathrm{mg} \mathrm{L}^{-1}$ (Vertimec $18 \mathrm{CE}^{\circledR}, 1 \mathrm{~mL} \mathrm{~L}^{-1}$ ),

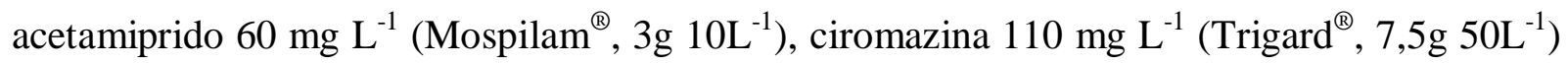

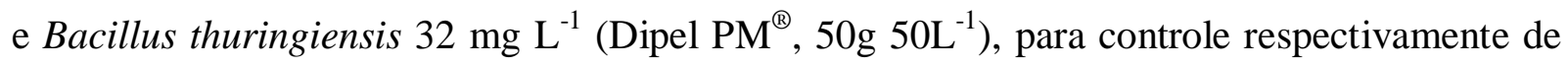
ácaros, pulgões, larva-minadora e broca das cucurbitáceas. 


\subsubsection{Manejo da irrigação e fertirrigação}

O manejo da irrigação foi realizado através de uma bateria de dois tensiômetros de mercúrio instalados em cada tratamento, em parcelas tomadas aleatoriamente (Figura 3). O primeiro tensiômetro, instalado a $10 \mathrm{~cm}$ de profundidade (em relação ao centro da cápsula porosa de $6 \mathrm{~cm}$ de comprimento), foi denominado tensiômetro de decisão, pois com base nessas leitura foram realizadas as irrigações. O segundo tensiômetro foi denominado tensiômetro de controle e instalado a $18 \mathrm{~cm}$ de profundidade (em relação ao centro da cápsula porosa), para controle da lâmina aplicada.

As leituras de tensiômetros foram feitas diariamente, com as irrigações realizadas nos tratamentos monitorados pelos tensiômetros, em intervalos variáveis de acordo com a demanda atmosférica.
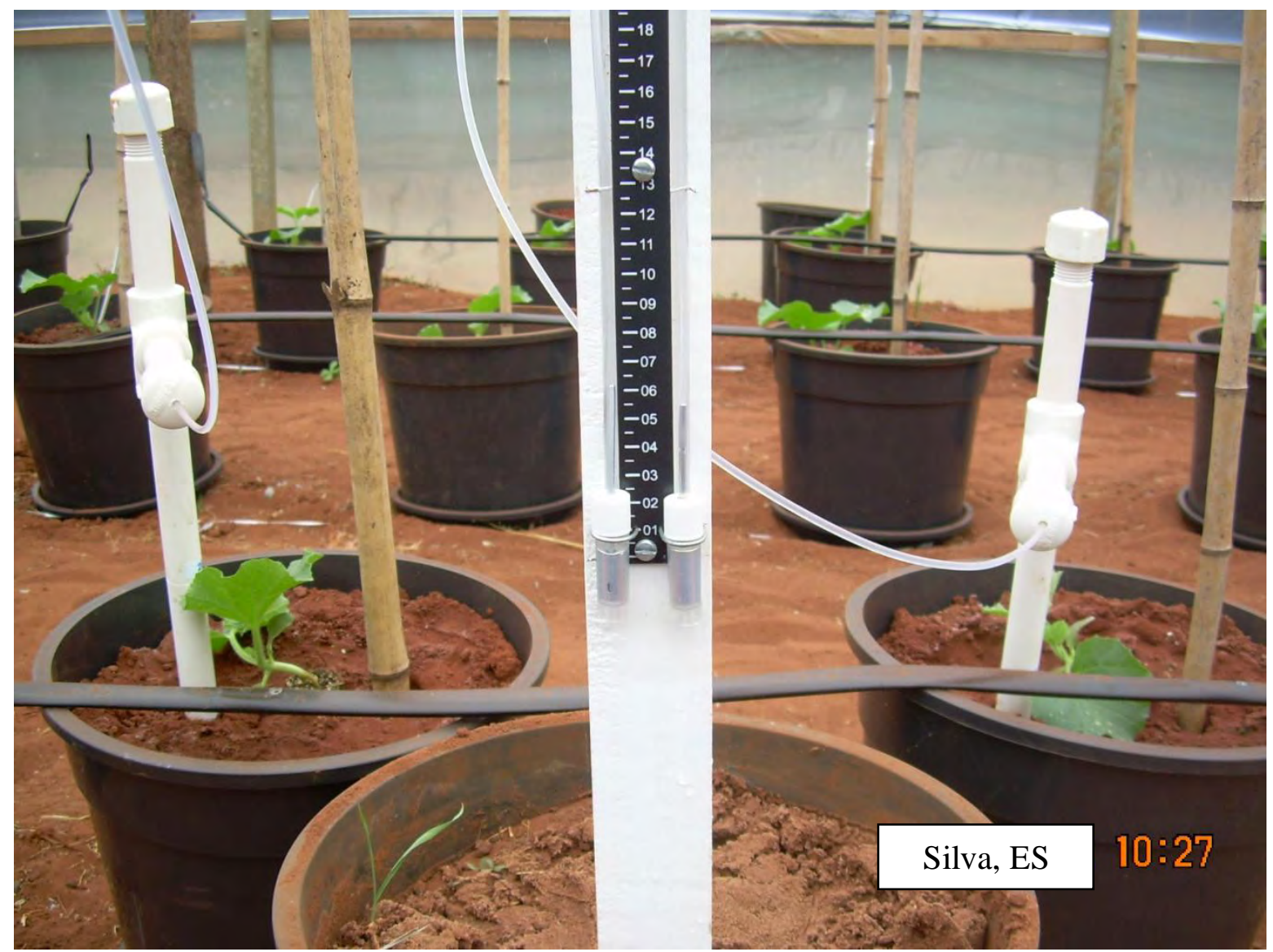

Figura 3. Tensiômetros de decisão e de controle, instalados na cultura do meloeiro. 


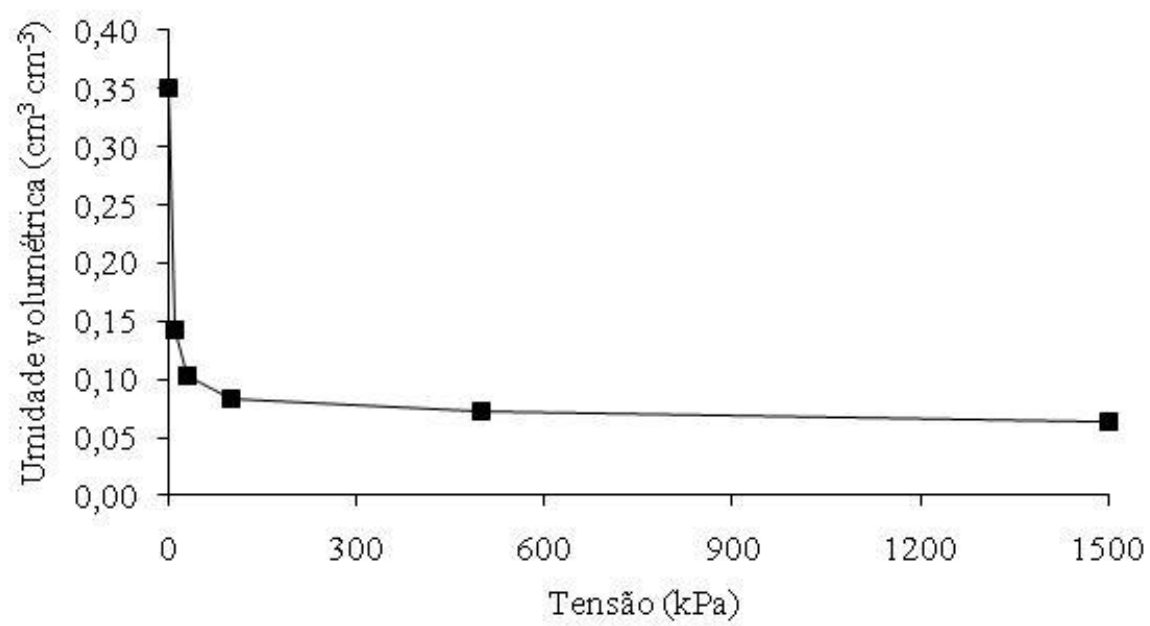

Figura 4. Curva de retenção de água no solo utilizada para o manejo das irrigações.

As irrigações foram realizadas para elevar o potencial de água no solo de $-25 \mathrm{kPa}$ para $-10 \mathrm{kPa}$, valores estes adotados respectivamente como tensão de irrigação e capacidade de campo para cultivo segundo Silva et al. (2005), com valores de umidade volumétrica correspondentes a 0,109 e $0,143 \mathrm{~cm}^{3} \mathrm{~cm}^{-3}$. A profundidade efetiva do sistema radicular (Z) adotada foi $20 \mathrm{~cm}$.

Uma vez que as curvas de $\psi_{\mathrm{m}}(\theta)$ ou então, $\theta\left(\psi_{\mathrm{m}}\right)$ foram levantadas experimentalmente, houve a necessidade de definir a melhor curva que se ajustasse aos dados experimentais. Entre os mais variados modelos, Reichardt \& Timm (2004) destacam o de Van Genuchten (1980), o qual foi utilizado baseado em parâmetros ajustados pelo método da minimização dos quadrados dos desvios. Essa equação é explicitada em termos de $\theta$. Neste, a equação foi ajustada empregando a ferramenta de otimização Solver do Excel.

$$
\theta=\theta_{R}+\frac{\left(\theta_{S}-\theta_{R}\right)}{\left[1+\left(\alpha \varphi_{m}\right)^{n}\right]^{m}}
$$

Em que: os parâmetros $\theta_{\mathrm{R}}, \mathrm{n}, \mathrm{m}$ e $\alpha$ foram obtidos por ajustes. $\theta_{\mathrm{S}}$ é o ponto da curva de retenção para $\psi_{\mathrm{m}}=0$, medido experimentalmente. 
Para a curva gerada (Figura 4) com os pontos médios das 5 amostras, obteve-se:

$$
\theta=0,061+\frac{(0,350-0,061)}{\left[1+\left(0,8744 \varphi_{\mathrm{m}}\right)^{1,5795}\right]^{0,3669}}
$$

Para determinar a umidade volumétrica na tensão de irrigação foi substituído o valor utilizado como referência ( $25 \mathrm{kPa}$ ) na equação, resultando numa umidade de $0,109 \mathrm{~cm}^{3} \mathrm{~cm}^{-3}$. Com base na umidade na capacidade de campo utilizada (10 Kpa) que possuía $0,143 \mathrm{~cm}^{3} \mathrm{~cm}^{-3}$ e pela diferença entre as duas, foi encontrado o volume de água 0,033 $\mathrm{cm}^{3} \mathrm{~cm}^{-3}$ necessário a ser aplicado por litro de solo e ao multiplicar pelo volume do vaso, no caso $10000 \mathrm{~cm}^{3}$, obtendo a lâmina total de irrigação por vaso de $330 \mathrm{~cm}^{3}$, considerando o peso específico da água de $1 \mathrm{~g} \mathrm{~cm}^{-3}$ na temperatura ambiente.

O sistema de irrigação adotado foi por gotejamento, com a vazão nominal de $1,67 \mathrm{~L} \mathrm{~h}^{-1}$ espaçados $0,50 \mathrm{~m}$.

As adubações foram realizadas via fertirrigação duas vezes por semana, à base de $200 \mathrm{~kg} \mathrm{ha}^{-1}$ de $\mathrm{N}=100 \mathrm{mg} \mathrm{N} \mathrm{L}^{-1}$ para cada tratamento e cinco concentrações diferentes de potássio: $0 ; 62,5 ; 125 ; 187,5 ; 250 \mathrm{mg} \mathrm{L}^{-1}$, segundo as dosagens de potássio estabelecidas, nas formas de nitrato de amônio e nitrato de potássio, de acordo com a marcha de absorção da cultura durante seu ciclo (KANO, 2002) e Tabela 7. 
Tabela 7. Extrações dos nutrientes nitrogênio $(\mathrm{N})$ e potássio $(\mathrm{K})$ pelo meloeiro rendilhado cultivado em ambiente protegido (adaptado de Kano, 2002).

\begin{tabular}{ccc}
\hline Semanas & \multicolumn{2}{c}{ Extração $\left(\% \mathrm{ha}^{-1} \mathrm{dia}^{-1}\right)$} \\
\hline 1 & $\mathrm{~N}$ & $\mathrm{~K}$ \\
2 & 1 & 1 \\
3 & 2 & 1 \\
4 & 3 & 2 \\
5 & 6 & 4 \\
6 & 9 & 8 \\
7 & 17 & 16 \\
8 & 28 & 18 \\
9 & 16 & 20 \\
10 & 7 & 18 \\
11 & 6 & 9 \\
12 & 3 & 2 \\
\hline
\end{tabular}

Utilizou-se extratores de solução para obter a solução do solo nos tratamentos das concentrações de potássio: 0; 125 e $250 \mathrm{mg} \mathrm{L}^{-1}$ para acompanhar a condutividade elétrica (CE) e $\mathrm{pH}$ do solo. Foi feito leitura de $\mathrm{CE}$ em dS $\mathrm{m}^{-1}$ utilizando um condutivímetro portátil e de $\mathrm{pH}$ utilizando um peagâmetro portátil.

\subsubsection{Medidas de trocas gasosas nas plantas}

As medidas foram realizadas sempre das 8:00 às 11:00 horas da manhã, nas plantas inoculadas e tratadas com potássio. Nos casos em que houve sobrevivência das plantas, durante o desenvolvimento dos frutos foram medidas as trocas gasosas sempre na folha da haste principal mais próxima ao fruto $\left(12^{\circ}\right.$ ou $13^{\circ}$ nó). Foi utilizado o medidor portátil de fotossíntese, com sistema aberto e analisador de $\mathrm{CO}_{2}$ por radiação infravermelha ("Infra Red Gas Analyser - IRGA", modelo LI-6400 da LI-COR). Os parâmetros mensurados foram: taxa de assimilação líquida de $\mathrm{CO}_{2}$ nas folhas (A) em $\mu \mathrm{mol} \mathrm{m} \mathrm{m}^{-2} \mathrm{~s}^{-1}$; condutância estomática

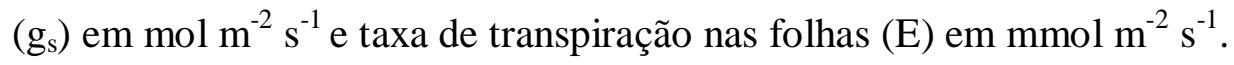




\subsubsection{Análise estatística}

Foi realizada por meio da análise de variância do fatorial (teste F) (Tabela 8) a 5\% de probabilidade. Nos casos em que as variâncias não foram homogenias para análise da variância, foram testadas transformações para os dados originais pelo teste de Levene para obter a que melhor homogeneizou as variâncias. O teste de Tukey a 5\% de probabilidade foi utilizado para comparar as médias.

Os dados foram plotados com o tempo (dias após inoculação), gerando as curvas de progresso do crestamento gomoso por isolados em cada porta-enxerto. Foi feita regressão linear entre os valores previstos (variável dependente) e observados (variável independente), ambos sem transformação, obtendo os valores de $\mathrm{R}^{*^{2}}$ para escolher o modelo matemático não linear que melhor representasse o progresso da doença segundo Campbell \& Madden (1990). Análise quanto ao paralelismo foi efetuado através do pacote estatístico ESTAT (UNESP-FCAV-C. Jaboticabal).

Nos casos em que a análise da variância do fatorial foi significativo para o fator concentrações de potássio, os dados foram submetidos à análise de regressão polinomial.

Tabela 8. Esquema de análise de variância dos experimentos.

\begin{tabular}{cc|ccccc}
\hline $1^{\circ}$ Experimento & \multirow{G}{*}{ GL } & $\begin{array}{c}2^{\circ} \text { Experimento } \\
\text { Causa da Variação }\end{array}$ & $\begin{array}{c}\mathrm{GL} \\
\mathrm{DML}^{1}\end{array}$ & $\begin{array}{c}\mathrm{GL} \\
\mathrm{N}^{\circ} \text { plantas }\end{array}$ & $\begin{array}{c}\mathrm{GL} \\
\text { Tausa da Variação }\end{array}$ & $\begin{array}{c}\mathrm{GL} \\
\mathrm{TG}^{2}\end{array}$ \\
\hline Isolados (I) & 4 & Tipo de planta (TP) & 1 & 2 & 2 & 1 \\
Porta-enxertos (PE) & 3 & Concentrações K (K) & 4 & 4 & 4 & 4 \\
I x PE & 12 & TP x K & 4 & 8 & 8 & 4 \\
Blocos & 5 & Blocos & 4 & 4 & 3 & 3 \\
Resíduo & 95 & Resíduo & 36 & 56 & 42 & 27 \\
Total & 119 & Total & 49 & 74 & 59 & 39 \\
\hline
\end{tabular}

$1^{\circ}$ Experimento: Reação de porta-enxertos de meloeiro a isolados de Didymella bryoniae.

$2^{\circ}$ Experimento: concentrações de potássio na resistência do meloeiro rendilhado híbrido 'Bônus II' enxertado e pé-franco a Didymella bryoniae.

${ }^{1}$ DML: Diâmetro médio de lesão

${ }^{2}$ TG: Trocas gasosas 
Nas avaliações de diâmetro médio de lesão (DML) no $2^{\circ}$ experimento existe grau de liberdade (GL) igual a um, para o fator tipo de planta (TP), pois foram avaliadas somente plantas enxertadas (Tabela 8).

A partir dos 33 dias após a inoculação (DAI) no $2^{\circ}$ experimento, as trocas gasosas (TG) em função da enxertia e concentrações de potássio, só foram avaliadas nas plantas enxertadas e utilizando quatro repetições, pois as plantas pé-franco não se apresentavam mais em quantidade suficiente, por isso existem duas colunas de grau de liberdade (Tabela 8). 


\section{RESULTADOS E DISCUSSÃO}

\subsection{Reação de porta-enxertos de meloeiro a isolados de Didymella bryoniae}

Os dados climáticos registrados através de termo-higrômetro digital referentes à umidade relativa do ar e às temperaturas mínima, média e máxima apresentaram faixas toleráveis para o desenvolvimento dos porta-enxertos (Figuras 5 e 6). A temperatura máxima e mínima variou entre 21,8 e $41,6{ }^{\circ} \mathrm{C} ; 20$ e $11,4{ }^{\circ} \mathrm{C}$ respectivamente. 


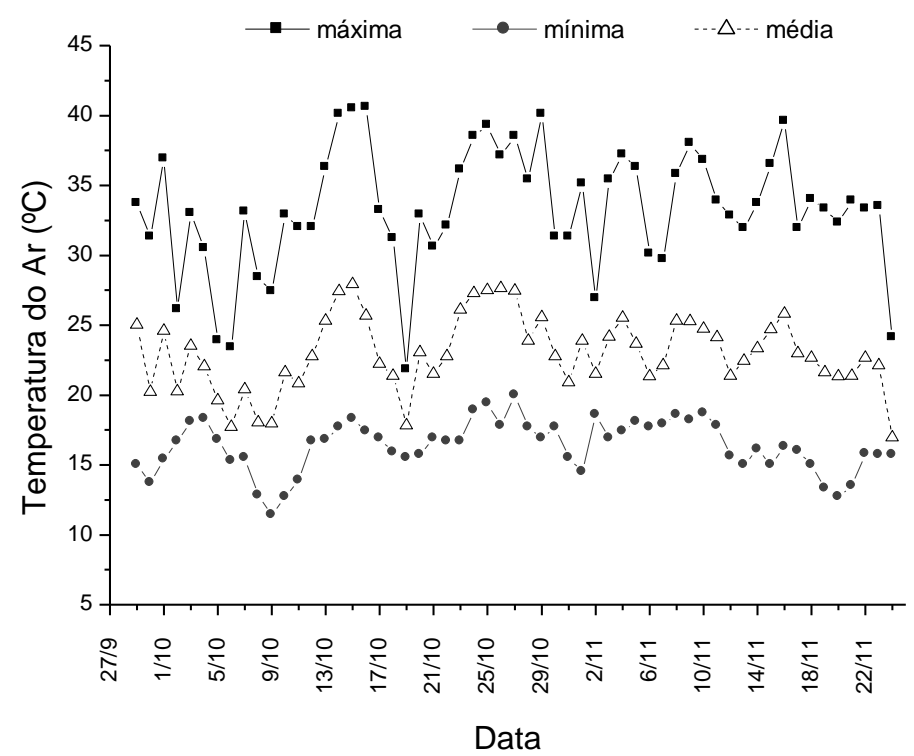

Figura 5. Temperatura máxima, mínima e média dentro do ambiente protegido no período de 29/09/2008 a 23/11/2008, em São Manuel-SP - FEPP - UNESP/FCA, 2009.

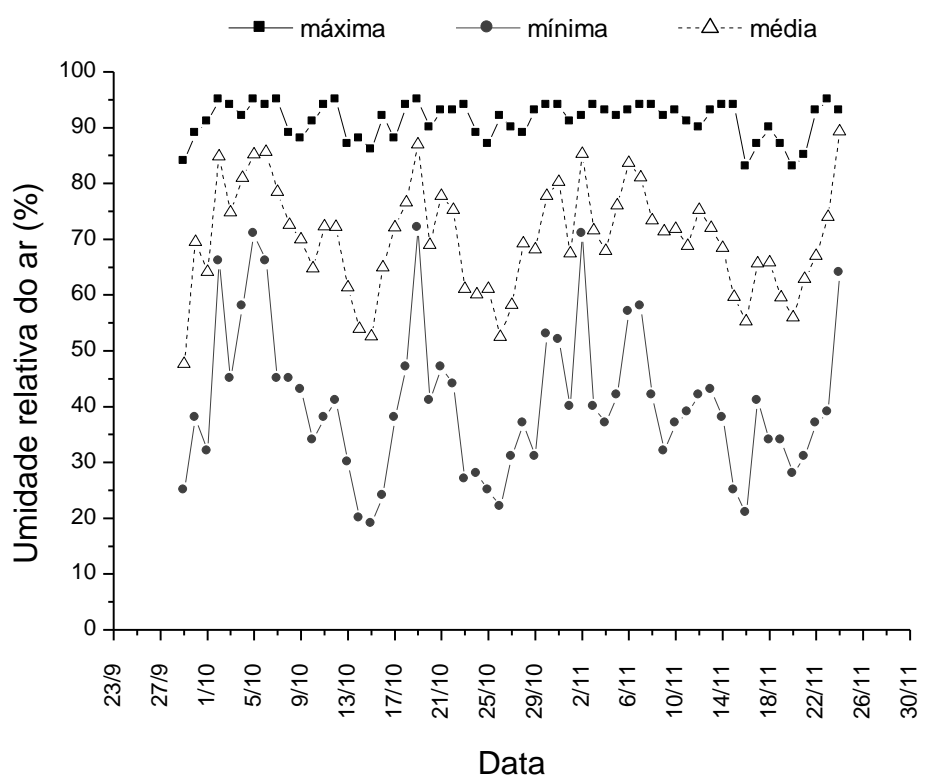

Figura 6. Umidade relativa máxima, mínima e média dentro do ambiente protegido no período de 29/09/2008 a 23/11/2008, São Manuel-SP - FEPP - UNESP/FCA, 2009. 
Os resultados da análise de variância são apresentados de forma resumida em tabelas contendo quadrados médios (QM) a cada avaliação nos respectivos dias após a inoculação (DAI).

O efeito principal dos isolados, dos porta-enxertos em todas as avaliações, e das interações dos dois fatores (isolados e porta-enxertos) aos 14, 21 e 28 dias após a inoculação (DAI), sobre o diâmetro médio da lesão $(\mathrm{cm})$ foram significativos (Tabela 9).

Tabela 9. Resumo da análise de variância (quadrados médios e coeficiente de variação) do diâmetro médio da lesão do fungo Didymella bryoniae, em função dos porta-enxertos (PE) e dos isolados provenientes de quatro regiões do Brasil. São Manuel-SP - FEPP UNESP/FCA, 2008.

\begin{tabular}{|c|c|c|c|c|c|c|c|c|}
\hline $\begin{array}{l}\text { Causa da } \\
\text { Variação }\end{array}$ & GL & $\begin{array}{l}\text { QM } 7 \\
\text { DAI }\end{array}$ & $\begin{array}{l}\text { QM } 14 \\
\text { DAI }\end{array}$ & $\begin{array}{c}\text { QM } 21 \\
\text { DAI }\end{array}$ & $\begin{array}{c}\text { QM } 28 \\
\text { DAI }\end{array}$ & $\begin{array}{c}\text { QM } 35 \\
\text { DAI }\end{array}$ & $\begin{array}{c}\text { QM 45 } \\
\text { DAI }\end{array}$ & $\begin{array}{c}\text { QM } 52 \\
\text { DAI }\end{array}$ \\
\hline Isolados (I) & 4 & $0,17 * *$ & $0,53 * *$ & $1,11 * *$ & $1,21 * *$ & $1,12 * *$ & $1,00 * *$ & $1,03 * *$ \\
\hline PE & 3 & $0,12 * *$ & $0,41 * *$ & $0,68 * *$ & $0,97 * *$ & $0,97 * *$ & $0,66^{* *}$ & $0,88 * *$ \\
\hline I x PE & 12 & $0,02^{\mathrm{ns}}$ & $0,11 * *$ & $0,23 * *$ & $0,23 * *$ & $0,17^{\mathrm{ns}}$ & $0,06^{\mathrm{ns}}$ & $0,09^{\mathrm{ns}}$ \\
\hline Blocos & 5 & $0,01^{\mathrm{ns}}$ & $0,02^{\mathrm{ns}}$ & $0,04^{\mathrm{ns}}$ & $0,03^{\mathrm{ns}}$ & $0,10^{\mathrm{ns}}$ & $0,22^{\mathrm{ns}}$ & $0,18^{\mathrm{ns}}$ \\
\hline Resíduo & 95 & 0,02 & 0,04 & 0,07 & 0,07 & 0,09 & 0,12 & 0,13 \\
\hline Total & 119 & & & & & & & \\
\hline $\mathrm{CV}(\%)$ & & 26,05 & 30,77 & 35,62 & 36,27 & 38,9 & 42,36 & 43,7 \\
\hline
\end{tabular}

Na primeira avaliação (sete dias após a inoculação) já foi perceptível a diferença do diâmetro médio de lesão causado pelos isolados Dbr 34, Dbr 36, Dbr 37 e Dbr 39 em relação ao controle e a diferença de reação dos porta-enxertos em relação aos isolados (Tabela 10). 
Tabela 10. Médias gerais do diâmetro médio da lesão em $\mathrm{cm}$ do fungo $D$. bryoniae, em função dos porta-enxertos (P.E.) e dos isolados provenientes de quatro regiões do Brasil. São ManuelSP - FEPP - UNESP/FCA, 2008.

\begin{tabular}{llllllll}
\hline & \multicolumn{7}{c}{ Dias após inoculação } \\
\cline { 2 - 8 } & $\mathbf{7}$ & $\mathbf{1 4}$ & $\mathbf{2 1}$ & $\mathbf{2 8}$ & $\mathbf{3 5}$ & $\mathbf{4 5}$ & $\mathbf{5 2}$ \\
\hline Isolados & & & & & & \\
\hline Dbr 34 & $0,53 \mathrm{a}$ & $0,61 \mathrm{~b}$ & $0,64 \mathrm{~b}$ & $0,68 \mathrm{~b}$ & $0,77 \mathrm{~b}$ & $0,86 \mathrm{a}$ & $0,87 \mathrm{a}$ \\
Dbr 36 & $0,52 \mathrm{ab}$ & $0,65 \mathrm{~b}$ & $0,76 \mathrm{~b}$ & $0,84 \mathrm{ab}$ & $0,88 \mathrm{ab}$ & $0,82 \mathrm{a}$ & $0,87 \mathrm{a}$ \\
Dbr 37 & $0,62 \mathrm{a}$ & $0,82 \mathrm{a}$ & $0,98 \mathrm{a}$ & $1,04 \mathrm{a}$ & $1,02 \mathrm{a}$ & $1,01 \mathrm{a}$ & $1,02 \mathrm{a}$ \\
Dbr 39 & $0,62 \mathrm{a}$ & $0,72 \mathrm{ab}$ & $0,83 \mathrm{ab}$ & $0,78 \mathrm{~b}$ & $0,84 \mathrm{ab}$ & $0,92 \mathrm{a}$ & $0,90 \mathrm{a}$ \\
Controle & $0,41 \mathrm{~b}$ & $0,42 \mathrm{c}$ & $0,40 \mathrm{c}$ & $0,43 \mathrm{c}$ & $0,44 \mathrm{c}$ & $0,47 \mathrm{~b}$ & $0,47 \mathrm{~b}$ \\
\hline PE & & & & & & & \\
\hline Calabash & $0,48 \mathrm{c}$ & $0,52 \mathrm{~b}$ & $0,58 \mathrm{~b}$ & $0,59 \mathrm{c}$ & $0,61 \mathrm{c}$ & $0,68 \mathrm{~b}$ & $0,67 \mathrm{~b}$ \\
Dinero & $0,58 \mathrm{ab}$ & $0,75 \mathrm{a}$ & $0,89 \mathrm{a}$ & $0,99 \mathrm{a}$ & $1,02 \mathrm{a}$ & $1,00 \mathrm{a}$ & $1,04 \mathrm{a}$ \\
Ojakyo & $0,49 \mathrm{bc}$ & $0,57 \mathrm{~b}$ & $0,61 \mathrm{~b}$ & $0,65 \mathrm{bc}$ & $0,70 \mathrm{bc}$ & $0,71 \mathrm{~b}$ & $0,71 \mathrm{~b}$ \\
Strong T. & $0,60 \mathrm{a}$ & $0,74 \mathrm{a}$ & $0,80 \mathrm{a}$ & $0,78 \mathrm{~b}$ & $0,82 \mathrm{ab}$ & $0,88 \mathrm{ab}$ & $0,89 \mathrm{ab}$ \\
\hline
\end{tabular}

Dados originais transformados em $\sqrt{ } \mathrm{x}$. Médias seguidas de mesma letra na coluna não diferem entre si pelo teste de Tukey a $5 \%$ de probabilidade.

Aos 14, 21 e 28 dias após a inoculação (DAI) foram observadas interações altamente significativas dos isolados do fungo D. bryoniae entre com as espécies de porta enxertos. O porta-enxerto 'Dinero' combinado com o isolado Dbr 37 apresentaram maior diâmetro médio da lesão aos 14, 21 e 28 DAI (Tabela 11), diferenciando-se estatisticamente dos demais portaenxertos.

Aos 14 DAI porta-enxerto melão 'Dinero' se mostrou susceptível ao isolado Dbr 36 não diferenciando do porta-enxerto abobora 'Strong Tosa'. Aos 21 DAÍ, os resultados foram semelhantes, porém os porta-enxertos cabaça 'Calabash' e melancia 'Ojakkyo' já se destacavam como mais resistentes.

No porta-enxerto 'Ojakyo' somente o isolado Dbr 37 foi significativo em relação ao controle. No porta-enxerto 'Strong Tosa' somente o isolado Dbr 39 foi significativo em relação ao controle aos 14 e 21 DAI (Tabela 11). 
Tabela 11. Diâmetro médio da lesão (cm) do fungo D. bryoniae aos 14, 21 e 28 DAI (Dias após inoculação). São Manuel-SP - FEPP - UNESP/FCA, 2008.

\begin{tabular}{|c|c|c|c|c|}
\hline & \multicolumn{3}{|c|}{ Porta enxertos } & \multirow[b]{2}{*}{ STRONG T. } \\
\hline & CALABASH & DINERO & OJAKYO & \\
\hline Isolados & \multicolumn{4}{|c|}{14 DAI } \\
\hline Dbr 34 & 0,56 aA & $0,59 \mathrm{bcA}$ & $0,54 \mathrm{abA}$ & $0,73 \mathrm{abA}$ \\
\hline Dbr 36 & $0,50 \mathrm{aB}$ & $0,84 \mathrm{bA}$ & $0,53 \mathrm{abB}$ & $0,74 \mathrm{abAB}$ \\
\hline Dbr 37 & $0,62 \mathrm{aB}$ & 1,19 aA & $0,75 \mathrm{aB}$ & $0,73 \mathrm{abB}$ \\
\hline Dbr 39 & $0,51 \mathrm{aB}$ & $0,79 \mathrm{bAB}$ & $0,63 \mathrm{abB}$ & 0,94 aA \\
\hline \multirow[t]{2}{*}{ Controle } & 0,40 aA & $0,35 \mathrm{cA}$ & $0,39 \mathrm{bA}$ & $0,54 \mathrm{bA}$ \\
\hline & \multicolumn{4}{|c|}{21 DAI } \\
\hline Dbr 34 & $0,63 \mathrm{abA}$ & $0,68 \mathrm{bcA}$ & $0,50 \mathrm{abA}$ & $0,75 \mathrm{bA}$ \\
\hline Dbr 36 & $0,53 \mathrm{abB}$ & $1,04 \mathrm{bA}$ & $0,72 \mathrm{abAB}$ & $0,76 \mathrm{bAB}$ \\
\hline Dbr 37 & $0,79 \mathrm{aB}$ & 1,53 aA & $0,80 \mathrm{aB}$ & $0,79 \mathrm{abB}$ \\
\hline Dbr 39 & $0,57 \mathrm{abB}$ & $0,88 \mathrm{bAB}$ & $0,66 \mathrm{abB}$ & $1,18 \mathrm{aA}$ \\
\hline \multirow[t]{2}{*}{ Controle } & $0,37 \mathrm{bA}$ & $0,35 \mathrm{cA}$ & $0,37 \mathrm{bA}$ & $0,51 \mathrm{bA}$ \\
\hline & \multicolumn{4}{|c|}{28 DAI } \\
\hline Dbr 34 & 0,68 aA & $0,69 \mathrm{cdA}$ & $0,56 \mathrm{abA}$ & 0,77 aA \\
\hline Dbr 36 & $0,52 \mathrm{aB}$ & $1,21 \mathrm{bA}$ & $0,74 \mathrm{abB}$ & 0,87 aAB \\
\hline Dbr 37 & $0,77 \mathrm{aB}$ & $1,68 \mathrm{aA}$ & $0,88 \mathrm{aB}$ & $0,83 \mathrm{aB}$ \\
\hline Dbr 39 & $0,55 \mathrm{aB}$ & $0,99 \mathrm{bcA}$ & $0,67 \mathrm{abAB}$ & 0,90 aAB \\
\hline Controle & $0,41 \mathrm{aA}$ & $0,40 \mathrm{dA}$ & 0,39 bA & $0,51 \mathrm{aA}$ \\
\hline
\end{tabular}

A análise dos modelos em ambos os porta enxertos, com base nos valores de $\mathrm{R}^{* 2}$ obtido da regressão linear entre os valores previstos (variável dependente) e observados (variável independente), ambos sem transformação, que segundo Campbell \& Madden (1990) representa melhor o progresso da doença, indicando o modelo monomolecular para as curvas de progresso, embora o modelo logístico também pudesse ter descrito muito bem a epidemia (Tabela 12). 
Tabela 12. Coeficiente de determinação $\left(\mathrm{R}^{* 2}\right)$, obtido da regressão linear entre os valores previstos (variável dependente) e observados (variável independente) para os porta-enxertos e os isolados de Didymela bryoniae. Botucatu-SP - UNESP/FCA, 2008.

\begin{tabular}{ccccc|cccc}
\hline & \multicolumn{3}{c}{ Logístico } & \multicolumn{5}{c}{ Monomolecular } \\
\hline & \multicolumn{9}{c}{ Porta enxertos } \\
\cline { 2 - 9 } Isolados & Calabash & Dinero & Ojakkyo & Strong & Calabash & Dinero & Ojakkyo & Strong \\
\hline Dbr 34 & 99,0 & 98,5 & 98,1 & 98,6 & 99,9 & 99,8 & 99,0 & 99,9 \\
Dbr 36 & 99,0 & 97,1 & 99,3 & 99,1 & 99,9 & 98,6 & 99,9 & 99,9 \\
Dbr 37 & 98,0 & 98,6 & 98,9 & 98,6 & 99,9 & 89,9 & 99,9 & 99,9 \\
Dbr 39 & 98,0 & 99,2 & 99,3 & 98,1 & 99,9 & 99,8 & 99,9 & 99,5 \\
Controle & 99,0 & 99,5 & 99,7 & 99,8 & 100,0 & 100,0 & 100,0 & 100,00 \\
\hline
\end{tabular}

Foi observado paralelismo para todas as retas dos isolados nos portaenxertos 'Calabash' e 'Dinero'. No porta-enxerto 'Strong Tosa' só não foi observado para os isolados Dbr 34 e Dbr 36. No porta-enxerto 'Ojakkyo' não houve paralelismo entre as retas (Tabela 13).

Tabela 13. Paralelismo das retas do diâmetro médio da lesão em função das épocas de avaliação em cada porta enxerto, efetuado através do pacote estatístico ESTAT (Jaboticabal). Botucatu-SP - UNESP/FCA, 2008.

\begin{tabular}{|c|c|c|c|c|c|c|c|c|c|}
\hline \multicolumn{10}{|c|}{ Porta enxertos } \\
\hline & \multicolumn{3}{|c|}{ CALABASH } & \multicolumn{3}{|c|}{ DINERO } & \multicolumn{3}{|c|}{ STRONG } \\
\hline Isolados & Dbr 36 & Dbr 37 & Dbr 39 & Dbr 36 & Dbr 37 & Dbr 39 & Dbr 36 & Dbr 37 & Dbr 39 \\
\hline Dbr 34 & $* *$ & $* *$ & $* *$ & ** & $* *$ & $* *$ & ns & $* *$ & $* *$ \\
\hline Dbr 36 & & $* *$ & $* *$ & & $* *$ & $* *$ & & $* *$ & $* *$ \\
\hline Dbr 37 & & & $* *$ & & & $* *$ & & & $* *$ \\
\hline
\end{tabular}

A diferença de agressividade dos isolados é claramente observada na análise do progresso da doença em todos os porta-enxertos, pelo nível do diâmetro médio da lesão tanto no início da epidemia quanto no final do período de avaliação. O isolado Dbr 37 foi o mais agressivo nos porta-enxertos 'Calabash', 'Dinero', 'Ojakkyo' causando o maior 
diâmetro médio de lesão $(3,68 \mathrm{~cm})$ no porta-enxerto 'Dinero'. O isolado Dbr 34 foi o menos agressivo em três dos quatro porta-enxertos testados, 'Dinero', 'Ojakkyo' e 'Strong Tosa'. O isolado Dbr 39 foi o mais agressivo no porta-enxerto 'Strong Tosa' causando um diâmetro médio de lesão crescente até os 21 DAI e em seguida diminuindo, porém mantendo-se mais agressivo que os demais isolados (Figura 7).
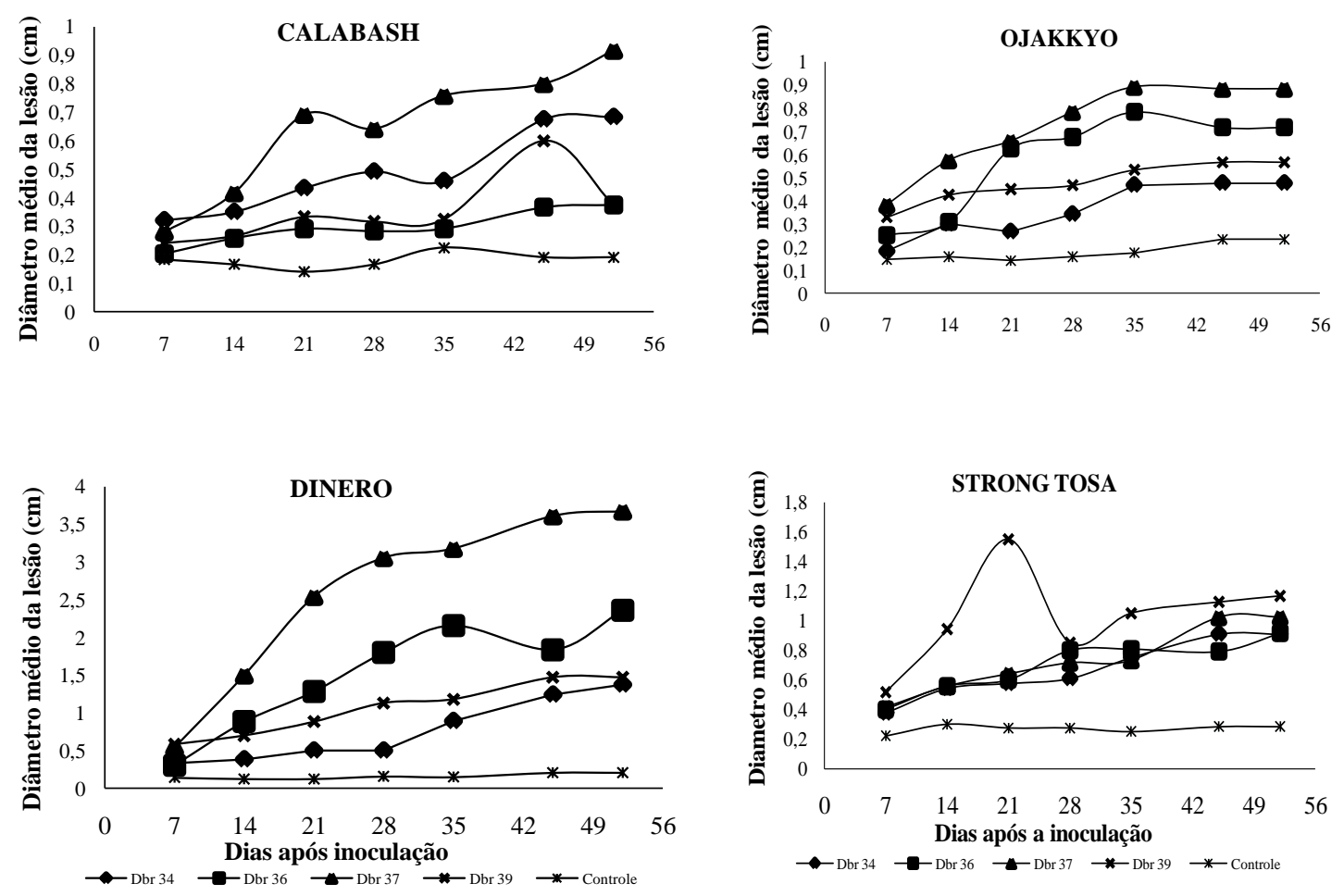

Figura 7. Progresso do crestamento gomoso ocasionado por isolados inoculados em porta enxertos de meloeiro. São Manuel-SP - FEPP - UNESP/FCA, 2008.

O porta-enxerto 'Dinero' apresentou maior diâmetro médio de lesão durante todo o período de avaliação (Figuras 7, 8 e 9) e foi considerado suscetível, assim como constataram Ito et al. (2009) que ao fazerem um estudo semelhante através da seleção de porta-enxertos resistentes à $D$. bryoniae testaram 17 genótipos de cucurbitáceas, dentre estes, apenas a melancia 'Charleston-Gray' e melão 'Redondo-Amarelo' foram suscetíveis ao patógeno. 


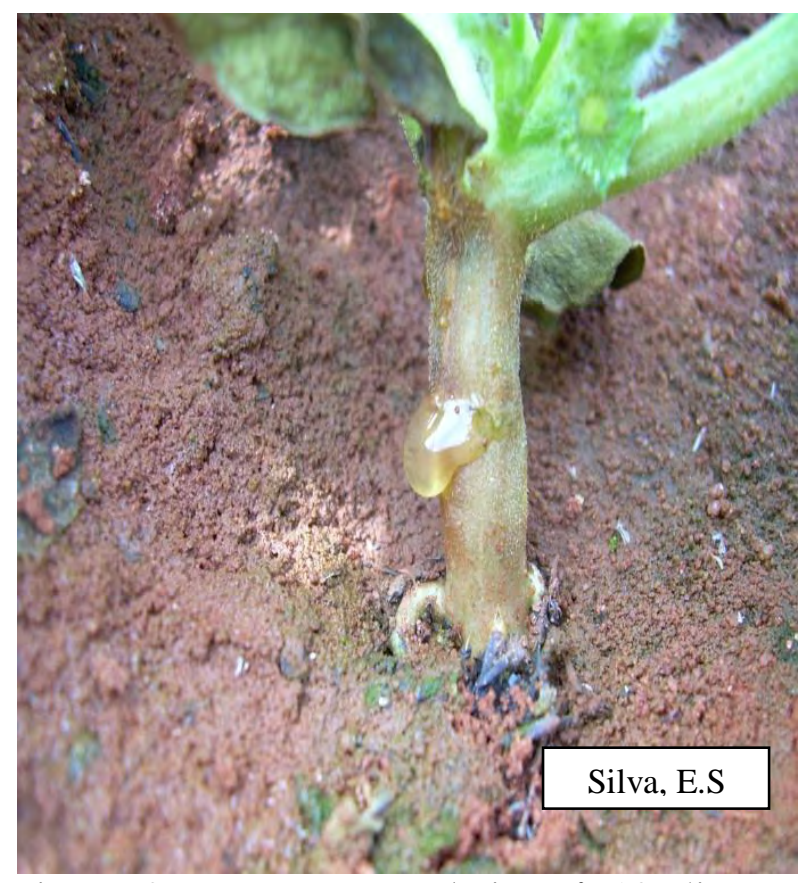

Figura 8. Porta-enxerto 'Dinero' 18 dias após inoculação.

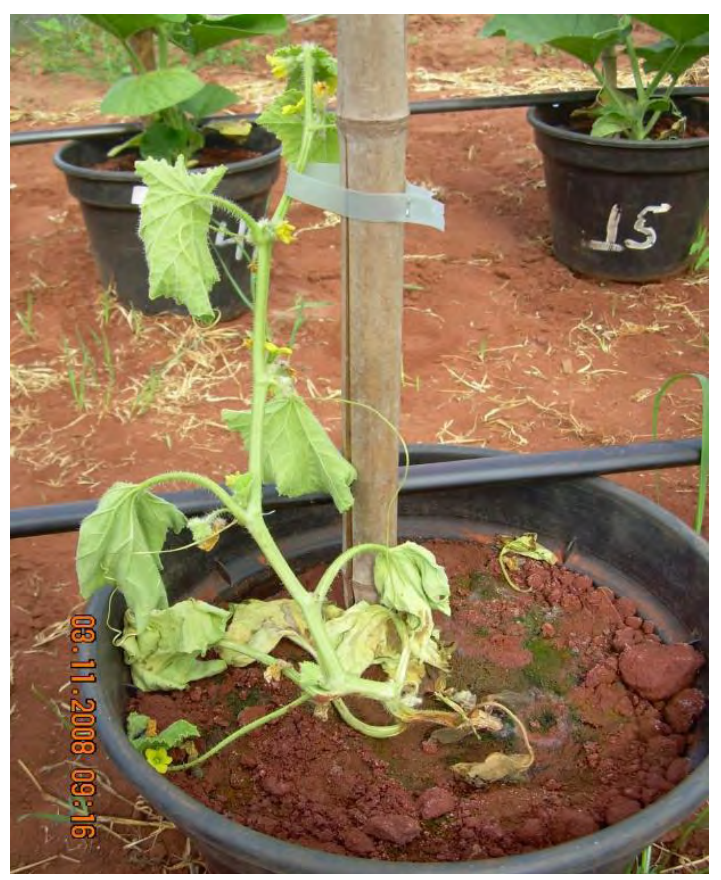

Figura 9. Porta-enxerto 'Dinero' 30 dias após inoculação.

O porta-enxerto 'Strong Tosa' até os 21 DAI mostrou-se susceptível ao isolado Dbr 39 (Figura 7), mas em seguida apresentou resistência parcial devido não aumentar significativamente o diâmetro médio de lesão, sendo considerado moderadamente resistente.

Os porta-enxertos melancia 'Ojakkyo' e cabaça 'Calabash TI-191' (Figura 10) apresentaram menor diâmetro médio de lesão durante todo o período de avaliação e foram considerados resistentes (Figura 7), podendo serem utilizados como porta-enxertos no meloeiro rendilhado visando ao controle do fungo D. bryoniae. 


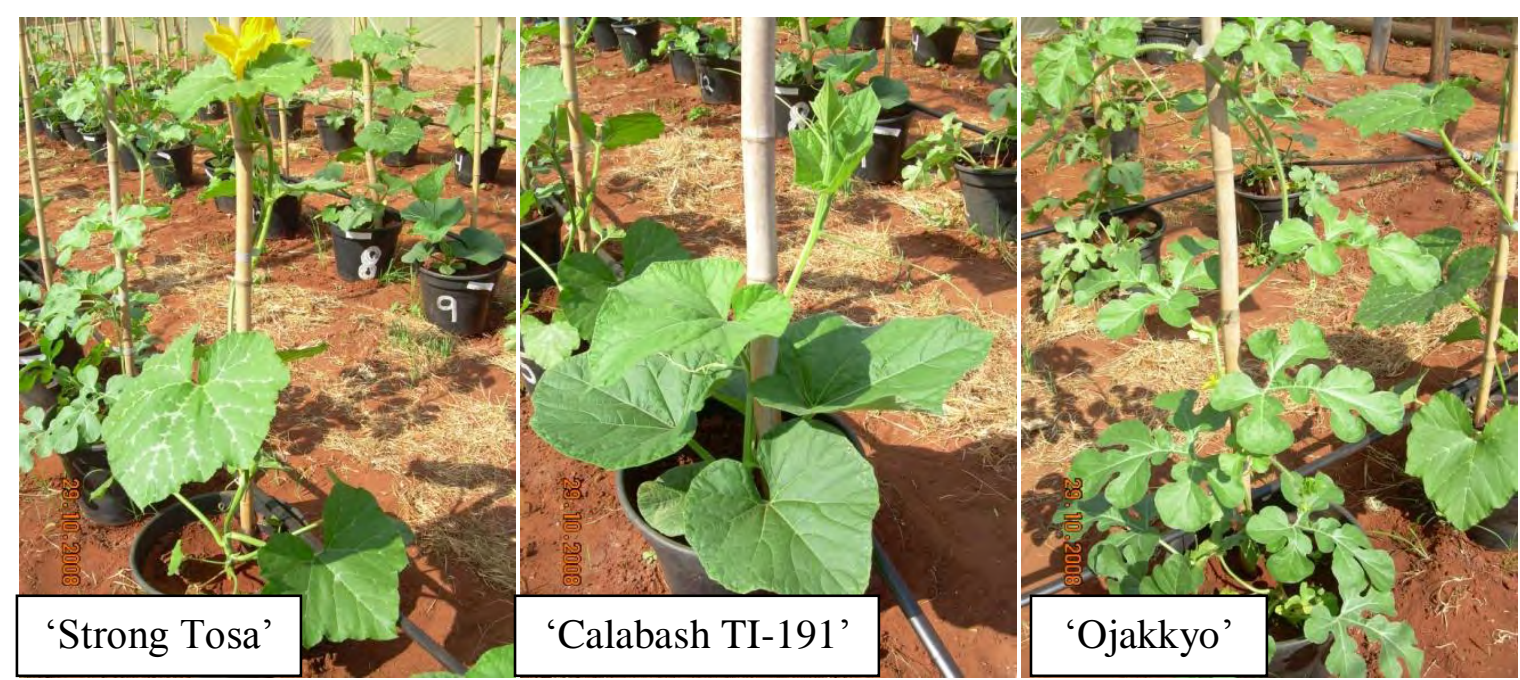

Figura 10. Porta-enxertos 'Strog Tosa', 'Calabash TI-191', 'Ojakkyo' 20 dias após inoculação.

Estes resultados concordam com Trionfetti-Nisini et al (2000) que ao avaliarem os porta-enxertos comerciais híbridos de melão 'ELSI', 'ES 99-13', 'RS 841' quanto à resistência a $D$. bryoniae em casa de vegetação observaram que os mesmos apresentaram um grau elevado de resistência ao fungo. Ito et al. (2009) ao testar 17 portaenxertos quanto à resistência a D. bryoniae, também obtiveram resultado semelhante em que Abóbora-Jacarezinho, abóbora 'Menina-Brasileira', moranga 'Exposição', moranga 'Coroa', abóbora 'Nova-Caravela', abóbora 'Squash', mogango 'Sul Mineiro', abóbora 'Mini-Paulista' e abóbora 'Goianinha', abobrinha italiana 'Caserta Melhorada', melão 'Redondo-Gaúcho', pepino 'Caipira HS - 221', pepino 'Caipira Rubi', Benincasa hispida e bucha foram resistentes.

Trionfetti-Nisini et al. (2000) e Crino et al. (2007) afirmam que a utilização de porta-enxertos resistentes a algumas doenças de solo pode ser uma alternativa de controle do crestamento gomoso aumentando a importância de estudos nessa área. 


\subsection{Concentrações de potássio na resistência do meloeiro rendilhado híbrido Bônus}

\section{II enxertado e pé-franco a Didymella bryoniae}

Os dados climáticos registrados no termo-higrômetro digital referentes às temperaturas mínima, média e máxima e à umidade relativa do ar apresentaram muitas variações, o que foi prejudicial ao desenvolvimento do meloeiro (Figuras 11 e 12).

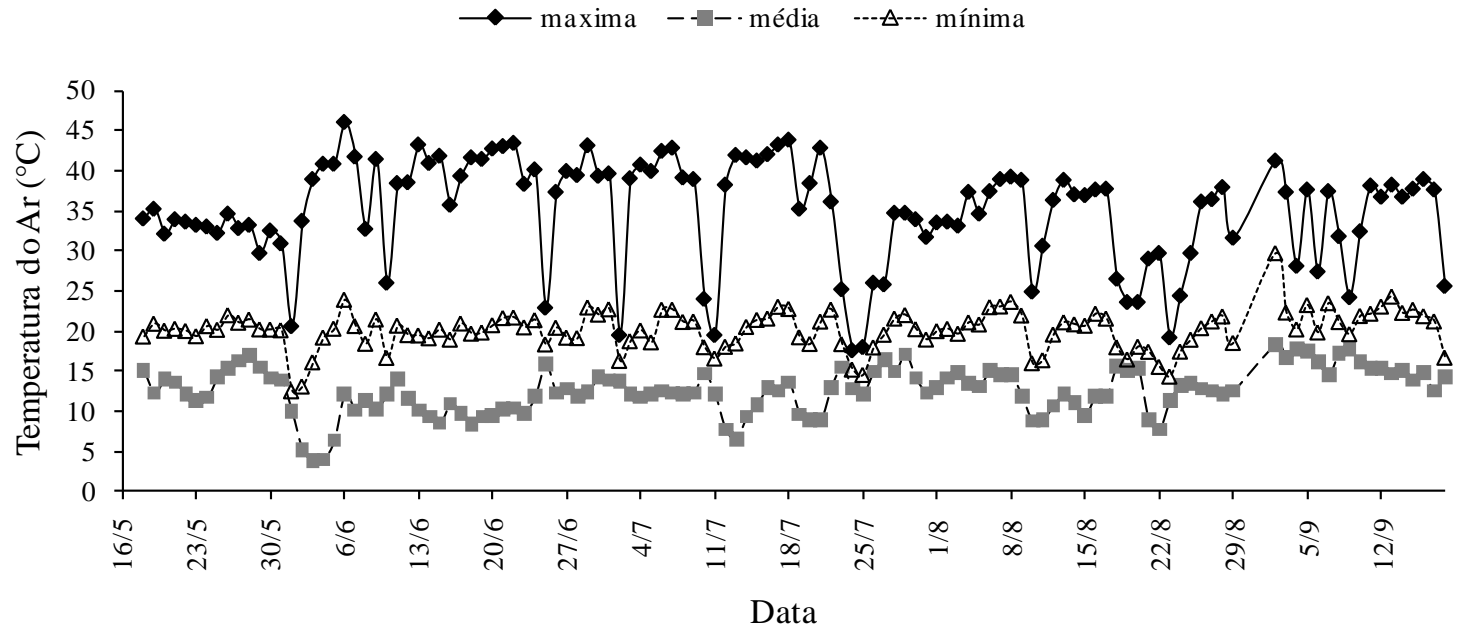

Figura 11. Temperatura máxima, mínima e média dentro do ambiente protegido de 18/05/2009 a 18/09/2009, São Manuel-SP - FEPP - UNESP/FCA, 2009.

A umidade relativa do ar máxima foi de $96 \%$ e a mínima de $15 \%$ (Figura 12), sendo que a faixa ideal durante o crescimento é de 60 a $70 \%$. 


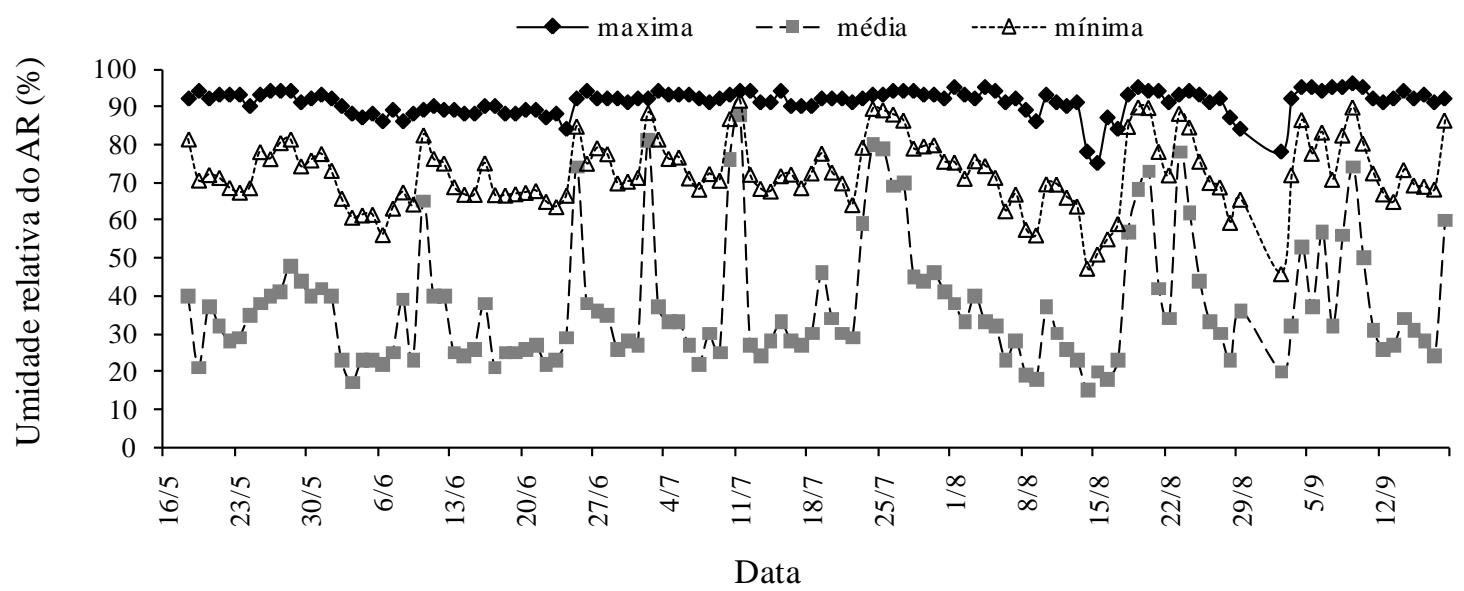

Figura 12. Umidade relativa máxima, mínima e média dentro do ambiente protegido de 18/05/2009 a 18/09/2009, São Manuel-SP - FEPP - UNESP/FCA, 2009.

\subsubsection{Pega de frutos}

O efeito principal do tipo de planta foi significativo e não significativo para as concentrações de K e interação dos dois fatores sobre a pega de frutos (Tabela 14).

Tabela 14. Resumo da análise de variância (quadrados médios e coeficiente de variação) da pega de frutos em plantas de 'Bônus II' pé-franco e enxertadas em melão 'Dinero' e abóbora 'Strong Tosa'. São Manuel-SP - FEPP - UNESP/FCA, 2009.

\begin{tabular}{ccc}
\hline Causa da Variação & GL & QM Pega de frutos \\
\hline Tipo de planta (TP) & 2 & $0,52^{*}$ \\
Concentrações K (K) & 4 & $0,21^{\text {ns }}$ \\
TP x K & 8 & $0,09^{\text {ns }}$ \\
Blocos & 4 & $0,78^{*}$ \\
Resíduo & 56 & 0,1 \\
Total & 74 & \\
\hline CV $(\%)$ & & 24,50
\end{tabular}

* Significativo a 5\% de probabilidade. ${ }^{\text {ns }}$ não significativo a 5\% de probabilidade. Dados originais transformados em $\sqrt{ }(x+0,5)$.

As plantas de 'Bônus II' enxertadas com abobora 'Strong Tosa' (40\%) e enxertadas com melão 'Dinero' (26\%) apresentaram maior porcentagem de pega de frutos, e 
não diferiram estatisticamente, já as não enxertadas apresentaram a menor porcentagem de pega de frutos (8\%) (Figura 13) diferindo estatisticamente das enxertadas.

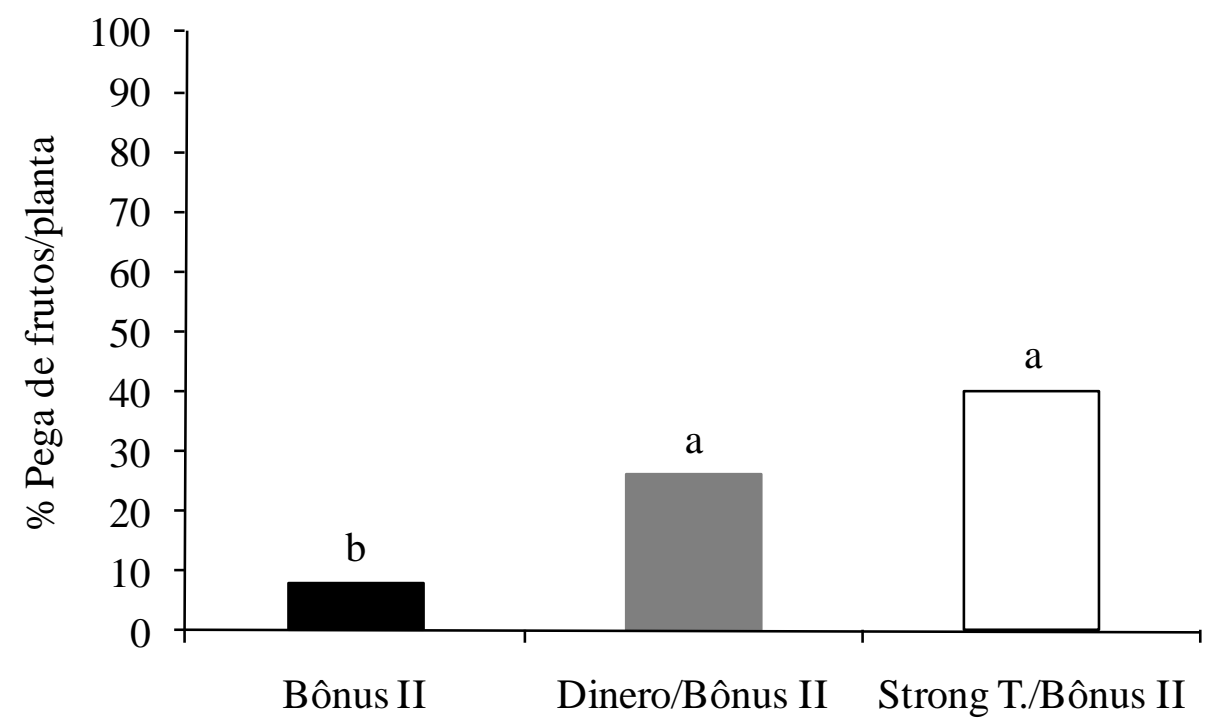

Figura 13. Porcentagem de pega de frutos em plantas de 'Bônus II' pé-franco e enxertadas em melão 'Dinero' e abóbora 'Strong Tosa'. Médias seguidas de mesma letra não diferem entre si pelo teste de Tukey a 5\% de probabilidade. São Manuel-SP - FEPP - UNESP/FCA, 2009.

Apesar da doença devastar as plantas pé-franco, as plantas enxertadas conseguiram produzir frutos mesmo que não comerciais. Além da presença da doença na época de frutificação pela Figura 11, observa-se que no período de cultivo houve grande variação da temperatura, sendo que a máxima chegou a $44^{\circ} \mathrm{C}$ e a mínima a $6^{\circ} \mathrm{C}$ prejudicando a cultura.

De acordo com Brandão Filho \& Vasconcellos (1998) e Moreira et al. (2009) temperaturas acima de $35{ }^{\circ} \mathrm{C}$ prejudicam o desenvolvimento da planta de meloeiro, provocando queda de flores e frutos novos, quando acompanhadas de ventos quentes causam rachaduras em frutos desenvolvidos e temperaturas abaixo de $15^{\circ} \mathrm{C}$ provocam a paralisação do crescimento e da atividade dos polinizadores, podendo terem sido os principais fatores para o abortamento dos frutos neste experimento. 


\subsubsection{Diâmetro médio da lesão em função das plantas enxertadas e concentrações de potássio.}

Em relação ao diâmetro médio da lesão só foram comparadas as médias das plantas enxertadas, devido à mortalidade das plantas pé-franco ter sido bem elevada.

O efeito principal das plantas enxertadas foi significativo em todas as avaliações, e não significativo para as concentrações de potássio e interação dos dois fatores sobre o diâmetro médio da lesão (Tabela 15).

Tabela 15. Resumo da análise de variância (quadrados médios e coeficiente de variação) do diâmetro médio da lesão em função do tipo de planta $(\mathrm{TP}=$ plantas enxertadas $) \mathrm{e}$ concentrações de potássio (K). São Manuel-SP - FEPP - UNESP/FCA, 2009.

\begin{tabular}{|c|c|c|c|c|c|c|c|c|c|}
\hline $\begin{array}{l}\text { Causa da } \\
\text { Variação }\end{array}$ & GL & $\begin{array}{l}\text { QM } 7 \\
\text { DAI } \\
\end{array}$ & $\begin{array}{l}\text { QM } 14 \\
\text { DAI }\end{array}$ & $\begin{array}{l}\text { QM 21 } \\
\text { DAI }\end{array}$ & $\begin{array}{l}\text { QM } 28 \\
\text { DAI }\end{array}$ & $\begin{array}{l}\text { QM } 35 \\
\text { DAI }\end{array}$ & $\begin{array}{l}\text { QM } 42 \\
\text { DAI }\end{array}$ & $\begin{array}{l}\text { QM } 49 \\
\text { DAI }\end{array}$ & $\begin{array}{l}\text { QM } 56 \\
\text { DAI }\end{array}$ \\
\hline $\mathrm{TP}$ & 1 & $3,32 *$ & $3,18^{*}$ & $3,00^{*}$ & $3,02 *$ & $2,73^{*}$ & $2,80^{*}$ & $2,57 *$ & $3,09 *$ \\
\hline $\mathrm{K}$ & 4 & $0,01^{\mathrm{ns}}$ & $0,02^{\mathrm{ns}}$ & $0,02^{\mathrm{ns}}$ & $0,01^{\mathrm{ns}}$ & $0,02^{\mathrm{ns}}$ & $0,01^{\mathrm{ns}}$ & $0,01^{\mathrm{ns}}$ & $0,01^{\mathrm{ns}}$ \\
\hline $\mathrm{TP} \times \mathrm{K}$ & 4 & $0,02^{\mathrm{ns}}$ & $0,03^{\mathrm{ns}}$ & $0,02^{\mathrm{ns}}$ & $0,01^{\mathrm{ns}}$ & $0,02^{\mathrm{ns}}$ & $0,01^{\mathrm{ns}}$ & $0,03^{\mathrm{ns}}$ & $0,04^{\mathrm{ns}}$ \\
\hline Blocos & 4 & $0,04^{*}$ & $0,02^{\mathrm{ns}}$ & $0,01^{\mathrm{ns}}$ & $0,01^{\mathrm{ns}}$ & $0,03^{\mathrm{ns}}$ & $0,02^{\mathrm{ns}}$ & $0,01^{\mathrm{ns}}$ & $0,01^{\mathrm{ns}}$ \\
\hline Resíduo & 36 & 0,01 & 0,02 & 0,01 & 0,02 & 0,02 & 0,02 & 0,01 & 0,02 \\
\hline Total & 49 & & & & & & & & \\
\hline $\mathrm{CV}(\%)$ & & 12,82 & 14,12 & 13,86 & 13,96 & 13,95 & 13,83 & 13,07 & 14,12 \\
\hline
\end{tabular}

As plantas de 'Bônus II' enxertadas no porta-enxerto melão 'Dinero' apresentaram maior diâmetro médio da lesão em todas avaliações, diferenciando-se bastante das plantas enxertadas no porta-enxerto abóbora 'Strong Tosa', chegando a 3,79 cm aos 56 DAI (dias após ao inoculação) (Figura 14).

Na maioria das plantas enxertadas em 'Dinero', a lesão evoluiu só na região do porta-enxerto (Figura 15), mas foi observado em algumas plantas que a lesão se desenvolveu até o enxerto, chegando a ocorrer a morte de algumas dessas plantas. 


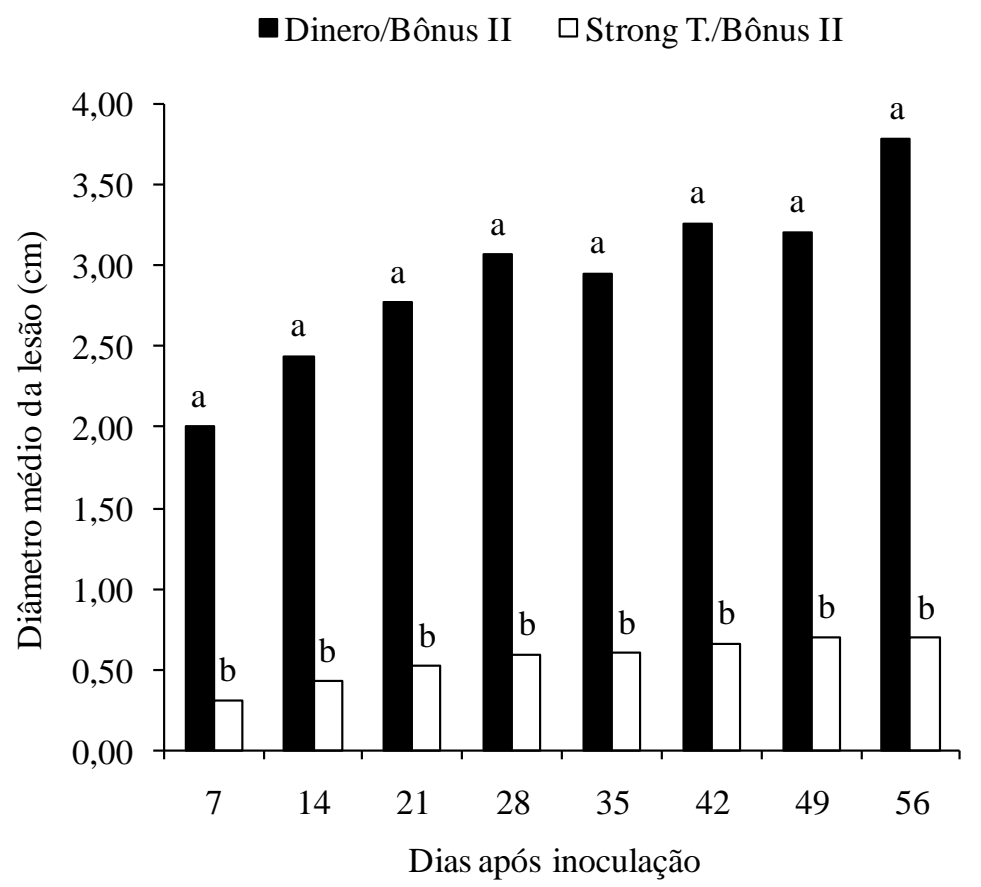

Figura 14. Diâmetro médio da lesão $(\mathrm{cm})$ na região do porta-enxerto em plantas de 'Bônus II' enxertadas nos porta-enxertos 'Strong Tosa' e 'Dinero'. Médias seguidas de mesma letra não diferem entre si pelo teste de Tukey ao nível de 5\% de probabilidade. São Manuel-SP - FEPP - UNESP/FCA, 2009.

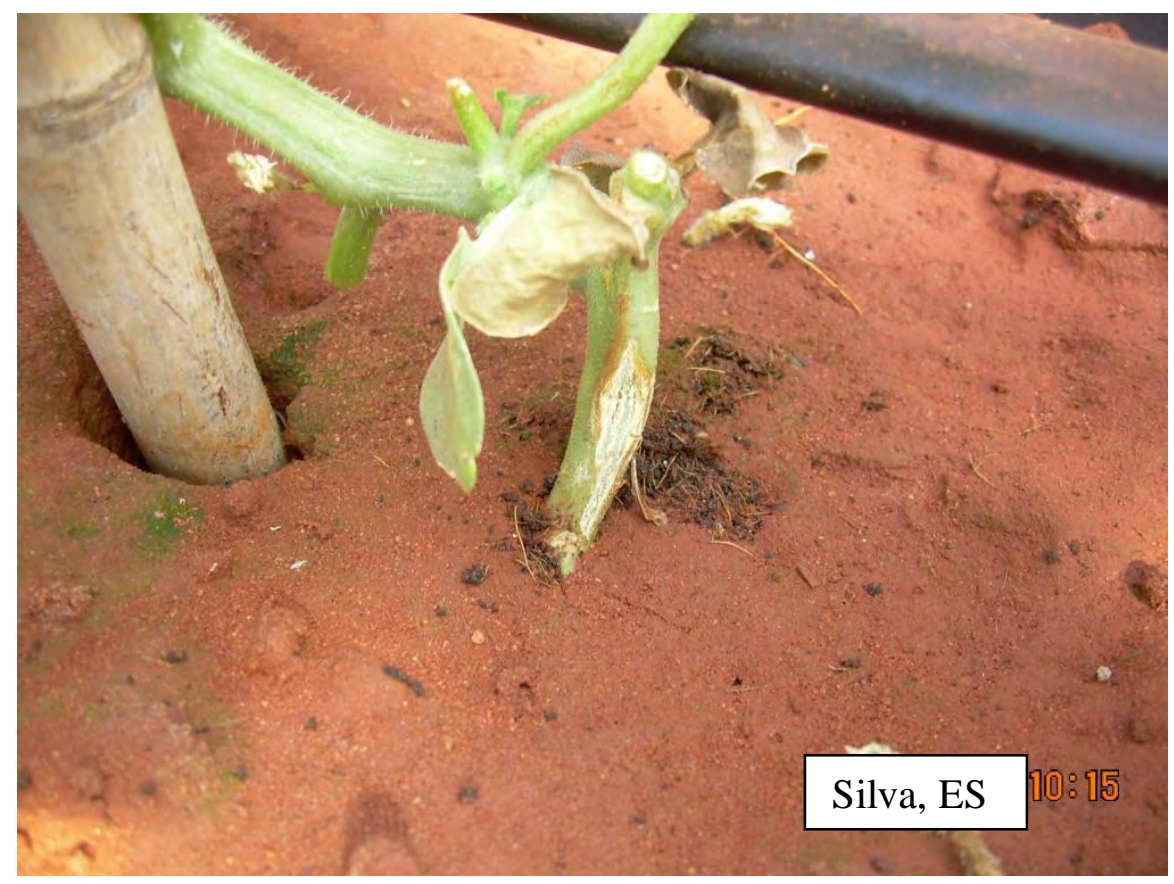

Figura 15. Lesão na região do porta-enxerto ‘Dinero’ aos 42 dias após inoculação. 
Em todas as plantas que se utilizou o porta-enxerto 'Strong Tosa' a lesão quase não se desenvolveu, sendo localizada somente na região do porta-enxerto (Figura 16) e o maior diâmetro médio de lesão observado nas plantas enxertadas foi $0,70 \mathrm{~cm}$ aos 49 DAI (Figura 14). A não expansão da lesão deve-se à resistência do porta-enxerto ao ataque do fungo, provavelmente pela síntese de novos carboidratos, principalmente calose e celulose, os quais são adicionados ao interior da parede celular. Segundo Matiello et al. (1997), isto ocorre quando o patógeno começa a penetrar na parede celular, com hifas ou haustórios infecciosos. Esta deposição de carboidratos continua após a penetração do patógeno, até que eles se tomem configurados como uma cúpula ou elongados, sendo denominados de papila (AIST, 1976).

Os resultados obtidos estão de acordo com Trionfetti-Nisini et al. (2000) que observaram em plantas de meloeiro cv. Proteo enxertadas em Benincasa hispida, Cucumis metuliferus e Cucumis moschata a ocorrência de sintomas de D. bryoniae, em que as lesões permaneceram confinadas nos porta-enxertos não afetando a planta enxertada.

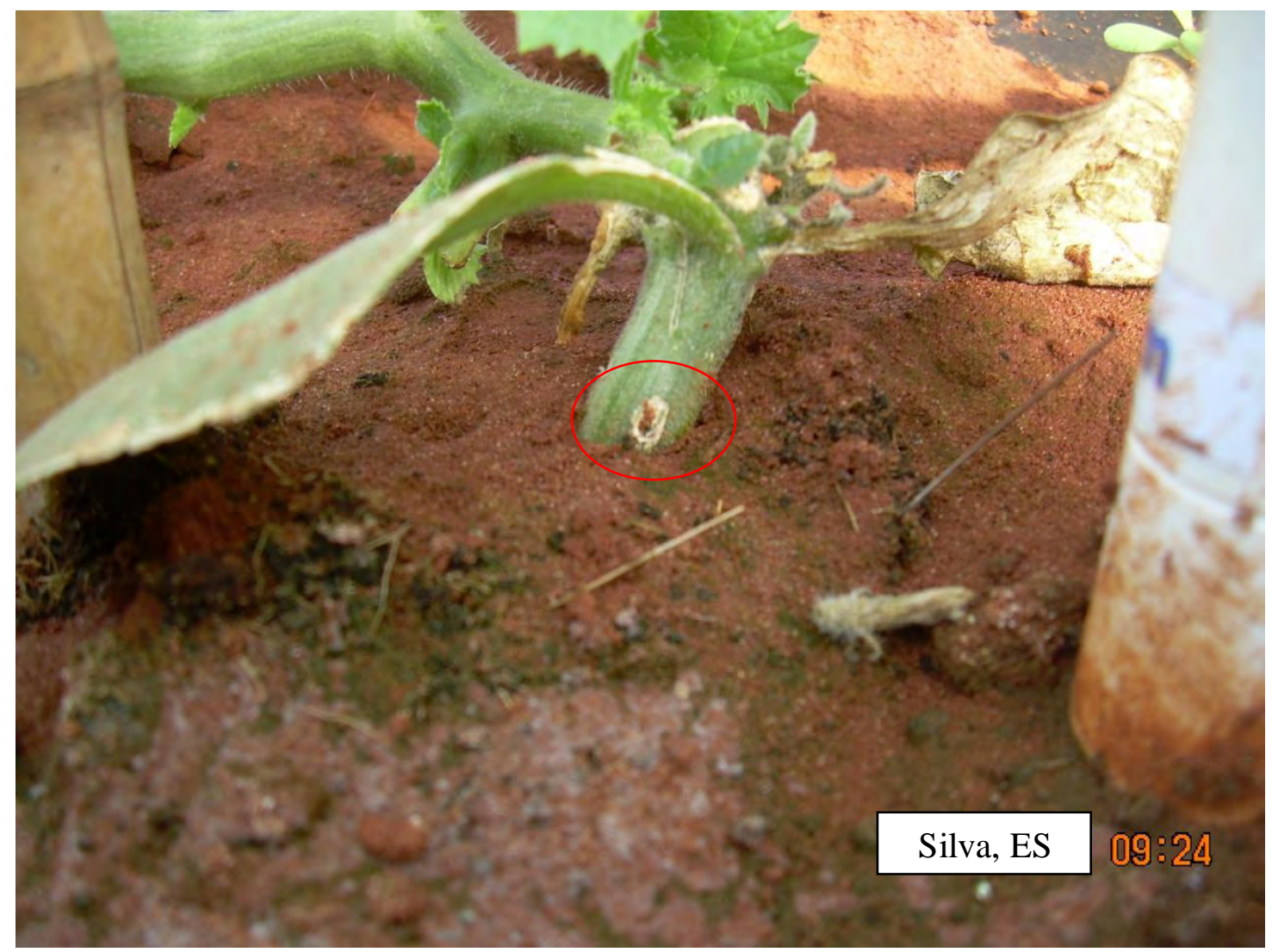

Figura 16. Lesão na região do porta-enxerto 'Strong Tosa' aos 42 dias após inoculação. 


\subsubsection{Sobrevivência das plantas em função da enxertia e concentrações de}

potássio

O efeito principal do fator tipo de planta (enxertada e pé-franco) foi significativo em todas as avaliações, e não significativo para as concentrações de potássio e interação dos dois fatores sobre a sobrevivência das plantas (Tabela 16).

Tabela 16. Resumo da análise de variância (quadrados médios e coeficiente de variação) do número médio de plantas por parcela em função do tipo de planta $(\mathrm{TP}=$ plantas enxertadas e pé-franco) e concentrações de potássio (K). São Manuel-SP - FEPP - UNESP/FCA, 2009.

\begin{tabular}{ccllllll}
\hline Causa da & & QM 14 & QM 21 & QM 28 & QM 35 & QM 42 & QM 49 \\
Variação & GL & DAI & DAI & DAI & DAI & DAI & DAI \\
\hline TP & 2 & $4,09^{*}$ & $10,84^{*}$ & $14,97^{*}$ & $18,76^{*}$ & $19,77^{*}$ & $19,77^{*}$ \\
K & 4 & $0,11^{\mathrm{ns}}$ & $0,20^{\mathrm{ns}}$ & $0,17^{\mathrm{ns}}$ & $0,05^{\mathrm{ns}}$ & $0,07^{\mathrm{ns}}$ & $0,07^{\mathrm{ns}}$ \\
TP x K & 8 & $0,09^{\mathrm{ns}}$ & $0,02^{\mathrm{ns}}$ & $0,26^{\mathrm{ns}}$ & $0,08^{\mathrm{ns}}$ & $0,11^{\mathrm{ns}}$ & $0,11^{\mathrm{ns}}$ \\
Blocos & 4 & $0,18^{\mathrm{ns}}$ & $0,27^{\mathrm{ns}}$ & $0,13^{\mathrm{ns}}$ & $0,25^{\mathrm{ns}}$ & $0,17^{\mathrm{ns}}$ & $0,17^{\mathrm{ns}}$ \\
Resíduo & 56 & 0,21 & 0,26 & 0,2 & 0,21 & 0,2 & 0,2 \\
Total & 74 & & & & & & \\
\hline CV $(\%)$ & & 26,59 & 31,84 & 29,51 & 30,50 & 30,67 & 30,67 \\
\hline
\end{tabular}

* Significativo a $5 \%$ de probabilidade. ${ }^{\text {ns }}$ não significativo a $5 \%$ de probabilidade.

A diferença entre número de plantas enxertadas e pé-franco sobreviventes durante todo o período de avaliação foi bastante visível, sendo que aos 14 dias após inoculação já existiam algumas plantas de 'Bônus II' pé-franco mortas com o caule cortado na região da lesão causada pelo fungo (Figura 17) e no decorrer do experimento não resistiram ao ataque do fungo $D$. bryoniae ocorrendo a morte de quase todas as plantas existentes (Figura 18). 


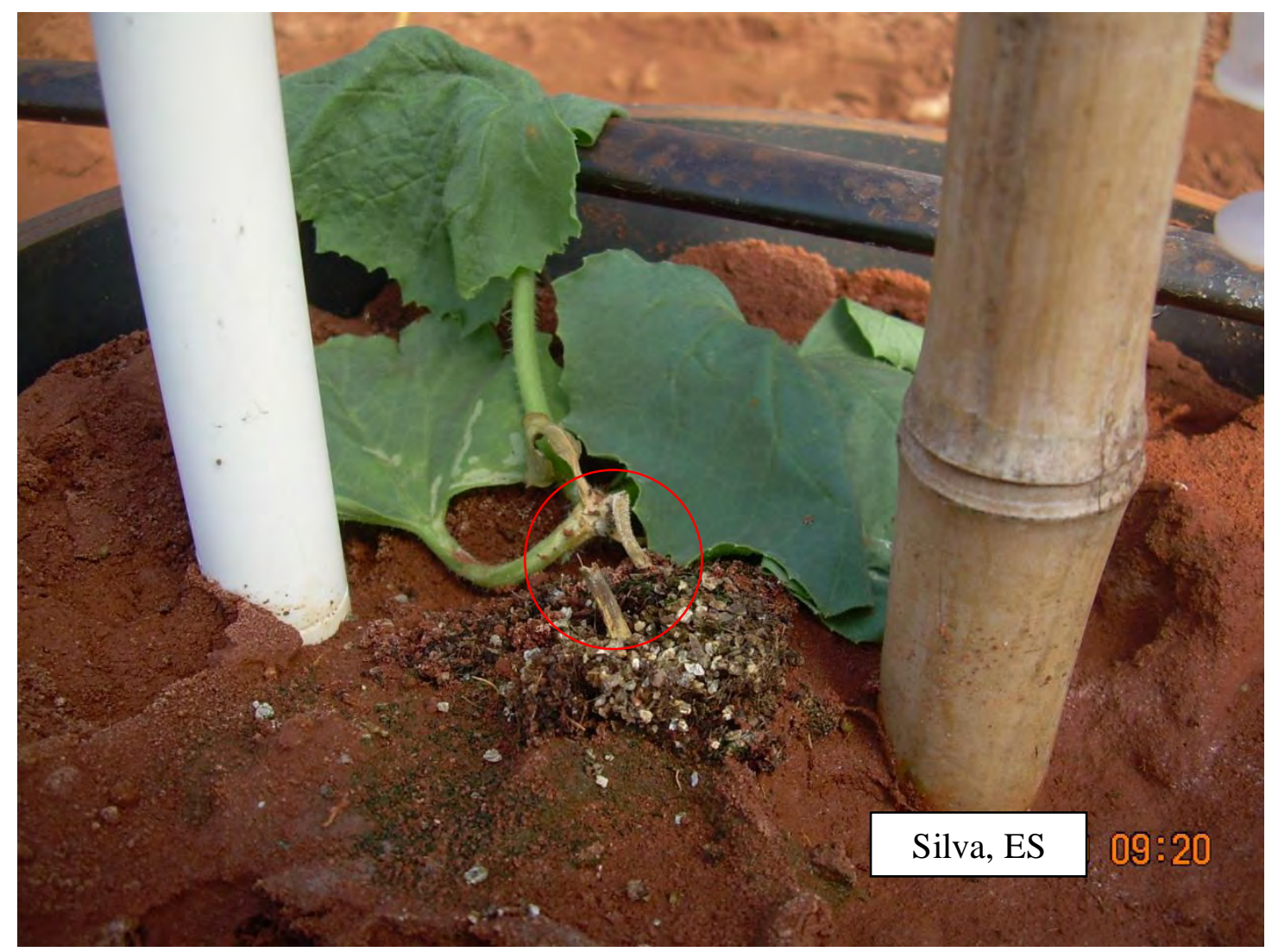

Figura 17. Planta de 'Bônus II’ pé-franco aos 14 dias após inoculação.

- Strong T./Bônus II $\square$ Dinero/Bônus II $\square$ Bônus II

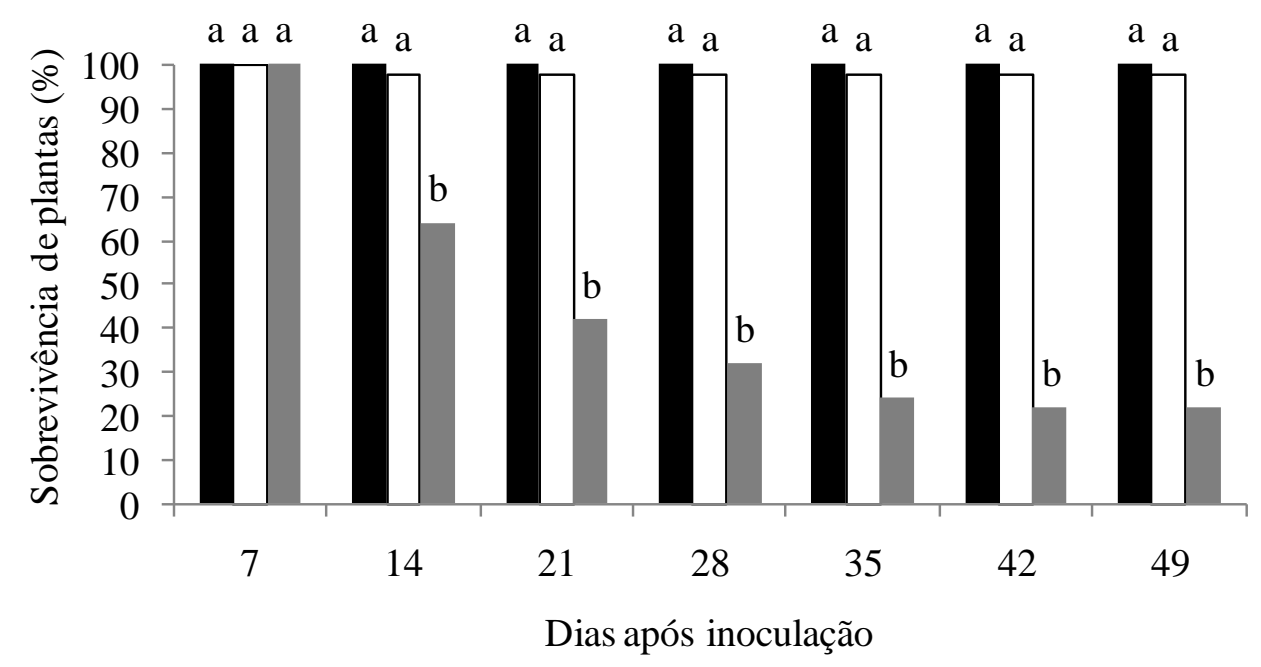

Figura 18. Sobrevivência de plantas de meloeiro (\%) enxertadas e pé-franco a cada sete dias após a inoculação. Médias seguidas de mesma letra não diferem entre si pelo teste de Tukey a 5\% de probabilidade. São Manuel-SP - FEPP - UNESP/FCA, 2009. 
Não ocorreu morte de nenhuma das plantas enxertadas no portaenxerto 'Strong Tosa' inoculada com o fungo D. bryoniae, porém não diferiu estatisticamente do número de plantas enxertadas no porta-enxerto 'Dinero', apesar de ter ocorrido a morte de algumas plantas enxertadas com este porta-enxerto (Figura 18). Esta resistência das plantas de 'Bônus II' enxertadas em abóbora 'Strong Tosa' em relação às enxertadas em melão 'Dinero' pode ser atribuída ao diâmetro médio de lesão menor (Figura 14).

Apesar do porta-enxerto 'Dinero' ter sido considerado susceptível no primeiro experimento, este foi utilizado no segundo experimento enxertado no híbrido de melão 'Bônus II'. Neste caso apresentou resistência ao fungo, pois a lesão se desenvolveu somente na região do porta-enxerto (Figura 15) na maioria das plantas, e não ocorreu número significativo de plantas mortas. Este fato pode ser atribuído a interação porta-enxerto/enxerto, já que as doses de K não influenciaram no tamanho da lesão e sobrevivência de plantas.

Estes resultados estão de acordo com Crino et al (2007) que observaram que plantas do híbrido de meloeiro 'Incas' enxertadas nos porta-enxertos comerciais 'RS 841', '360 P', 'ES 99-13', 'Elsi' foram altamente resistentes tanto para a raça 1 e 2 de Fusarium oxysporum f. sp. melonis (sobrevivência de $100 \%$ ) quanto para D. bryoniae com lesões quase ausentes e folhas com baixo índice de doença, deferindo claramente das enxertadas em 'Belimo', 'Energia', 'Griffin', 'ES liscio' e o controle 'Incas' na forma de péfranco.

As concentrações de potássio $(\mathrm{K})$ não influenciaram tanto no diâmetro médio da lesão quanto na sobrevivência das plantas (Tabelas 15 e 16), apesar da literatura registrar 2449 indicações sobre as relações entre potássio e sanidade da planta com relação a doenças e pragas, destacando-se maior relação com as doenças fúngicas (PERRENOUD, 1990; MALAVOLTA, 2006). No entanto, os resultados obtidos também estão de acordo com Santos et al. (2005) que avaliaram diferentes doses de nitrogênio e potássio em cobertura sobre o cancro da haste causado por $D$. bryoniae em melancia e também observaram que a adubação não influenciou na severidade da doença, como ocorreu neste ensaio. Prabhu et al. (2007) também apresentaram dados que evidenciam o efeito de K aumentando, diminuindo ou não influenciando na ocorrência de doenças, obtido em mais de 200 estudos em que 155 estão relacionados com doenças fúngicas e em 15 deles o potássio não influenciou na doença. 
Mesmo não ocorrendo influência do potássio sobre o diâmetro da lesão e na severidade causada pelo fungo $D$. bryoniae, a literatura evidencia que existem correlações entre o estado nutricional de $\mathrm{K}$ da planta e a incidência de doenças, mas segundo Amtmann et al. (2008) também é clara a necessidade de estudos relacionados aos efeitos de $\mathrm{K}$ sobre processos fisiológicos, metabólicos e hormonais, que tendem a ser cruciais para a susceptibilidade e sensibilidade de plantas aos agentes patogênicos e insetos, para melhor estabelecer estas correlações.

\subsubsection{Trocas gasosas em função da enxertia e concentrações de potássio}

Apesar das concentrações de potássio não influenciarem no diâmetro médio da lesão e nem na sobrevivência das plantas, estas tiveram influência nas trocas gasosas das plantas (Tabelas 17, 18 e 19).

$\mathrm{O}$ efeito principal do tipo de planta (enxertada e pé-franco $=\mathrm{TP}$ ) foi significativo aos 41 dias DAI sobre a taxa de assimilação líquida de $\mathrm{CO}_{2}(\mathrm{~A})$, condutância estomática $\left(\mathrm{g}_{\mathrm{s}}\right)$, taxa de transpiração (E) e eficiência do uso da água (EUA) (Tabelas 17, 18, 19 e 20).

Houve efeito principal das concentrações de potássio (K) aos 75 DAI sobre a taxa de assimilação líquida de $\mathrm{CO}_{2}$ (A) (Tabela 17), aos 75 e 82 DAI sobre a condutância estomática (Tabela 18) e aos 26 e 75 sobre taxa de transpiração (Tabela 19). A interação dos dois fatores (TP e K) mostrou efeito significativo sobre a condutância estomática aos 26 dias após a inoculação (Tabela 18). 
Tabela 17. Resumo da análise de variância (quadrados médios e coeficiente de variação) da taxa de assimilação líquida de $\mathrm{CO}_{2}$ em função do tipo de planta $(\mathrm{TP}=$ plantas enxertadas e péfranco) e concentrações de potássio (K). São Manuel-SP - FEPP - UNESP/FCA, 2009.

\begin{tabular}{|c|c|c|c|c|c|c|c|c|}
\hline Causa da Variação & GL & $\begin{array}{l}\text { QM } 14 \\
\text { DAI }\end{array}$ & $\begin{array}{l}\text { QM } 26 \\
\text { DAI }\end{array}$ & GL & $\begin{array}{l}\text { QM } 33 \\
\text { DAI }\end{array}$ & $\begin{array}{l}\text { QM } 41 \\
\text { DAI }\end{array}$ & $\begin{array}{l}\text { QM } 75 \\
\text { DAI }\end{array}$ & $\begin{array}{l}\text { QM } 82 \\
\text { DAI }\end{array}$ \\
\hline Tipo de planta (TP) & 2 & $13,53^{\mathrm{ns}}$ & $34,69^{\mathrm{ns}}$ & 1 & $4,62^{\mathrm{ns}}$ & $125,03 *$ & $36,67^{\mathrm{ns}}$ & $0,24^{\mathrm{ns}}$ \\
\hline Concentrações K $(\mathrm{K})$ & 4 & $33,33^{\mathrm{ns}}$ & $116,47^{\mathrm{ns}}$ & 4 & $13,69^{\mathrm{ns}}$ & $31,74^{\mathrm{ns}}$ & $142,47 *$ & $35,44^{\mathrm{ns}}$ \\
\hline $\mathrm{TP} \times \mathrm{K}$ & 8 & $57,32^{\mathrm{ns}}$ & $94,00^{\mathrm{ns}}$ & 4 & $55,67^{\mathrm{ns}}$ & $33,43^{\mathrm{ns}}$ & $10,99^{\mathrm{ns}}$ & $8,16^{\mathrm{ns}}$ \\
\hline Blocos & 3 & $64,88^{\mathrm{ns}}$ & $58,17^{\mathrm{ns}}$ & 3 & $3,23^{\mathrm{ns}}$ & $90,25 *$ & $25,02^{\mathrm{ns}}$ & $7,07^{\mathrm{ns}}$ \\
\hline Resíduo & 42 & 35,46 & 47,85 & 27 & 45,79 & 30,34 & 21,81 & 16,75 \\
\hline Total & 59 & & & 39 & & & & \\
\hline $\mathrm{CV}(\%)$ & & 35,37 & 46,63 & & 24,23 & 29,99 & 49,03 & 88,28 \\
\hline
\end{tabular}

* Significativo a $5 \%$ de probabilidade. ${ }^{\text {ns }}$ não significativo a $5 \%$ de probabilidade.

Tabela 18. Resumo da análise de variância (quadrados médios e coeficiente de variação) da condutância estomática em função do tipo de planta ( $\mathrm{TP}=$ plantas enxertadas e pé-franco) e concentrações de potássio (K). São Manuel-SP - FEPP - UNESP/FCA, 2009.

\begin{tabular}{|c|c|c|c|c|c|c|c|c|}
\hline Causa da Variacão & GI & $\begin{array}{l}\text { QM } 14 \\
\text { DAI }\end{array}$ & $\begin{array}{l}\text { QM } 26 \\
\text { DAI }\end{array}$ & GL & $\begin{array}{l}\text { QM } 33 \\
\text { DAI }\end{array}$ & $\begin{array}{c}\text { QM } 41 \\
\text { DAI }\end{array}$ & $\begin{array}{c}\text { QM } 75 \\
\text { DAI }\end{array}$ & $\begin{array}{c}\text { QM } 82 \\
\text { DAI }\end{array}$ \\
\hline Tipo de planta (TP) & 2 & $0,02^{\mathrm{ns}}$ & $0,05^{\text {ns }}$ & 1 & $0,06^{\mathrm{ns}}$ & $0,42 *$ & $0,01^{\mathrm{ns}}$ & $0,003^{\text {ns }}$ \\
\hline Concentrações K (K) & 4 & $0,05^{\text {ns }}$ & $0,11^{\text {ns }}$ & 4 & $0,02^{\text {ns }}$ & $0,04^{\text {ns }}$ & $0,05^{*}$ & $0,03 *$ \\
\hline $\mathrm{TP} \times \mathrm{K}$ & 8 & $0,51^{\text {ns }}$ & $0,23^{*}$ & 4 & $0,08 \mathrm{~ns}$ & $0,05^{\mathrm{ns}}$ & $10,99^{\text {ns }}$ & $0,01^{\mathrm{ns}}$ \\
\hline Blocos & 3 & $1,01^{\mathrm{ns}}$ & $0,07^{\mathrm{ns}}$ & 3 & $0,53^{*}$ & $0,06^{\mathrm{ns}}$ & $0,01^{\mathrm{ns}}$ & $0,02^{\mathrm{ns}}$ \\
\hline Resíduo & 42 & 0,12 & 0,09 & 27 & 0,13 & 0,04 & 0,001 & 0,01 \\
\hline Total & 59 & & & 39 & & & & \\
\hline $\mathrm{CV}(\%)$ & & 32,05 & 45,03 & & 52,44 & 28,45 & 42,12 & 38,33 \\
\hline
\end{tabular}

* Significativo a 5\% de probabilidade. ${ }^{\text {ns }}$ não significativo a $5 \%$ de probabilidade. Dados originais transformados em $\sqrt{ }(\log (x+1))$. 
Tabela 19. Resumo da análise de variância (quadrados médios e coeficiente de variação) da taxa de transpiração em função do tipo de planta ( $\mathrm{TP}=$ plantas enxertadas e pé-franco) e concentrações de potássio (K). São Manuel-SP - FEPP - UNESP/FCA, 2009.

\begin{tabular}{ccllcllll}
\hline & & QM 14 & QM 26 & & QM 33 & QM 41 & QM 75 & QM 82 \\
Causa da Variação & GL & DAI & DAI & GL & DAI & DAI & DAI & DAI \\
\hline Tipo de planta (TP) & 2 & $3,55^{\text {ns }}$ & $10,22^{\text {ns }}$ & 1 & $12,84^{\text {ns }}$ & $33,64^{*}$ & $0,14^{\text {ns }}$ & $0,07^{\text {ns }}$ \\
Concentrações K (K) & 4 & $16,33^{\text {ns }}$ & $28,96^{*}$ & 4 & $6,64^{\text {ns }}$ & $3,17^{\text {ns }}$ & $5,81^{*}$ & $12,31^{\text {ns }}$ \\
TP x K & 8 & $15,29^{\text {ns }}$ & $18,37^{\text {ns }}$ & 4 & $9,95^{\text {ns }}$ & $2,08^{\text {ns }}$ & $0,46^{\text {ns }}$ & $3,01^{\text {ns }}$ \\
Blocos & 3 & $16,12^{\text {ns }}$ & $25,08^{\text {ns }}$ & 3 & $4,54^{\text {ns }}$ & $39,40^{*}$ & $6,28^{*}$ & $6,85^{\text {ns }}$ \\
Resíduo & 42 & 11,5 & 10,64 & 27 & 8,55 & 6,3 & 1,73 & 5,44 \\
Total & 59 & & & 39 & & & & \\
\hline CV $(\%)$ & & 51,27 & 57,04 & & 60,81 & 38,19 & 69,65 & 76,82 \\
\hline
\end{tabular}

*Significativo a $5 \%$ de probabilidade. ${ }^{\text {ns }}$ não significativo a $5 \%$ de probabilidade.

Tabela 20. Resumo da análise de variância (quadrados médios e coeficiente de variação) da eficiência do uso da água em função do tipo de planta (TP= plantas enxertadas e pé-franco) e concentrações de potássio (K). São Manuel-SP - FEPP - UNESP/FCA, 2009.

\begin{tabular}{|c|c|c|c|c|c|c|c|c|}
\hline Causa da Variação & GL & $\begin{array}{l}\text { QM } 14 \\
\text { DAI }\end{array}$ & $\begin{array}{l}\text { QM } 26 \\
\text { DAI }\end{array}$ & GL & $\begin{array}{l}\text { QM } 33 \\
\text { DAI }\end{array}$ & $\begin{array}{l}\text { QM } 41 \\
\text { DAI }\end{array}$ & $\begin{array}{l}\text { QM } 75 \\
\text { DAI }\end{array}$ & $\begin{array}{l}\text { QM } 82 \\
\text { DAI }\end{array}$ \\
\hline Tipo de planta (TP) & 2 & $0,08^{\mathrm{ns}}$ & $3,99^{\mathrm{ns}}$ & 1 & $107,42^{\mathrm{ns}}$ & $4,17 *$ & $74,26^{\mathrm{ns}}$ & $33,11^{\mathrm{ns}}$ \\
\hline Concentrações K (K) & 4 & $1,37^{\mathrm{ns}}$ & $4,98^{\mathrm{ns}}$ & 4 & $27,26^{\mathrm{ns}}$ & $0,42^{\mathrm{ns}}$ & $39,58^{\mathrm{ns}}$ & $50,66^{\mathrm{ns}}$ \\
\hline $\mathrm{TP} \times \mathrm{K}$ & 8 & $0,49^{\mathrm{ns}}$ & $4,25^{\mathrm{ns}}$ & 4 & $70,52^{\mathrm{ns}}$ & $0,13^{\mathrm{ns}}$ & $13,06^{\mathrm{ns}}$ & $31,30^{\mathrm{ns}}$ \\
\hline Blocos & 3 & $2,46 *$ & $4,70^{\mathrm{ns}}$ & 3 & $55,19^{\mathrm{ns}}$ & $12,23 *$ & $51,48^{\mathrm{ns}}$ & $48,71^{\text {ns }}$ \\
\hline Resíduo & 42 & 0,76 & 4,24 & 27 & 46,37 & 1,99 & 34,9 & 42,92 \\
\hline Total & 59 & & & 39 & & & & \\
\hline $\mathrm{CV}(\%)$ & & 28,67 & 58,94 & & 13,97 & 2,11 & 12,46 & 16,37 \\
\hline
\end{tabular}

*Significativo a $5 \%$ de probabilidade. ${ }^{\text {ns }}$ não significativo a $5 \%$ de probabilidade.

Ao fazer o desdobramento do fator TP dentro de $\mathrm{K}$ com relação a condutância estomática aos 26 DAI, não foi observado diferença significativa para as médias (Tabela 21). 
Tabela 21. Médias gerais da condutância estomática em função do tipo de planta (TP= plantas enxertadas e pé-franco) e concentrações de potássio (K) aos 26 DAI. São Manuel-SP - FEPP UNESP/FCA, 2009.

\begin{tabular}{lccccc}
\hline & \multicolumn{5}{c}{ Concentrações K $\left(\mathrm{mg} \mathrm{L}^{-1}\right)$} \\
\cline { 2 - 6 } Tipo de planta & 0 & 62,5 & 125 & 187,5 & 250 \\
\hline Bônus II & $3,14 \mathrm{a}$ & $0,92 \mathrm{a}$ & $0,80 \mathrm{a}$ & $0,18 \mathrm{a}$ & $0,13 \mathrm{a}$ \\
Dinero/Bônus II & $0,71 \mathrm{a}$ & $0,59 \mathrm{a}$ & $0,25 \mathrm{a}$ & $1,34 \mathrm{a}$ & $0,67 \mathrm{a}$ \\
Strong T./Bônus II & $0,50 \mathrm{a}$ & $1,47 \mathrm{a}$ & $1,40 \mathrm{a}$ & $0,92 \mathrm{a}$ & $1,18 \mathrm{a}$ \\
\hline
\end{tabular}

De acordo com análise de regressão polinomial, as concentrações de potássio influenciaram de forma linear na condutância estomática e transpiração das plantas de Bônus II pé-franco aos 26 DAI (Tabela 22).

Tabela 22. Resumo da análise de variância (quadrados médios) da condutância estomática ( $\left.\mathrm{g}_{\mathrm{s}}\right)$ e taxa de transpiração (E) nas plantas de Bônus II aos 26 DAI. São Manuel-SP - FEPP UNESP/FCA, 2009.

\begin{tabular}{lcc}
\hline Causa da Variação & \multicolumn{2}{c}{ QM 26 DAI } \\
\hline Variável Significativa & $\mathrm{g}_{\mathrm{s}}$ & $\mathrm{E}$ \\
Cúbico & $0,94 \mathrm{~ns}$ & $0,20 \mathrm{~ns}$ \\
Quadrático & $4,25 \mathrm{~ns}$ & $3,09 \mathrm{~ns}$ \\
Linear & $18,31^{*}$ & $145,66^{*}$ \\
\hline
\end{tabular}

* Significativo a $5 \%$ de probabilidade. ${ }^{\text {ns }}$ não significativo a $5 \%$ de probabilidade.

Foi observado nesta avaliação que ao aumentar as concentrações de K diminuiu condutância estomática e taxa de transpiração (Figuras 19 e 20).

Apesar do ácido abscísico (ABA) não ter sido medido, a manutenção do fechamento parcial dos estômatos, a diminuição da condutância estomática e taxa de transpiração pode ser devido à permanência de altos teores desse hormônio nas células guardas, sintetizado em função do estresse causado pelas injúrias da doença ou pelo estresse salino com o aumento das concentrações de $K$, já que a temperatura e radiação fotossinteticamente ativa (PAR) nesta avaliação praticamente não variaram (Tabela 23). 
Segundo Liang et al. (1997), altos teores de ABA é um dos fatores de pós-estresse que influencia o mecanismo de abertura e fechamento de estômatos. Como observado por Gomes et al.(2004) ao submeterem laranjeiras 'Pêra' a estresse hídrico, a deficiência hídrica aumentou o conteúdo de $\mathrm{ABA}$, com consequiente fechamento estomático e decréscimo na condutância estomática.

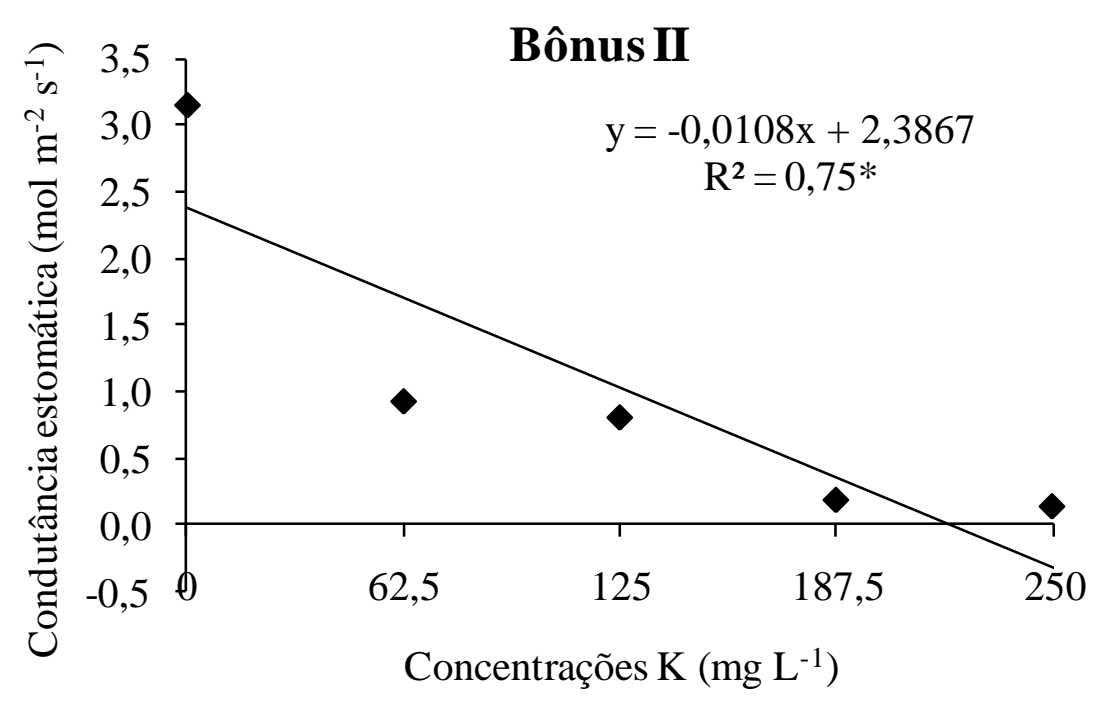

Figura 19. Condutância estomática em plantas de 'Bônus II' pé-franco em função das concentrações de potássio aos 26 DAI. São Manuel-SP - FEPP - UNESP/FCA, 2009. 


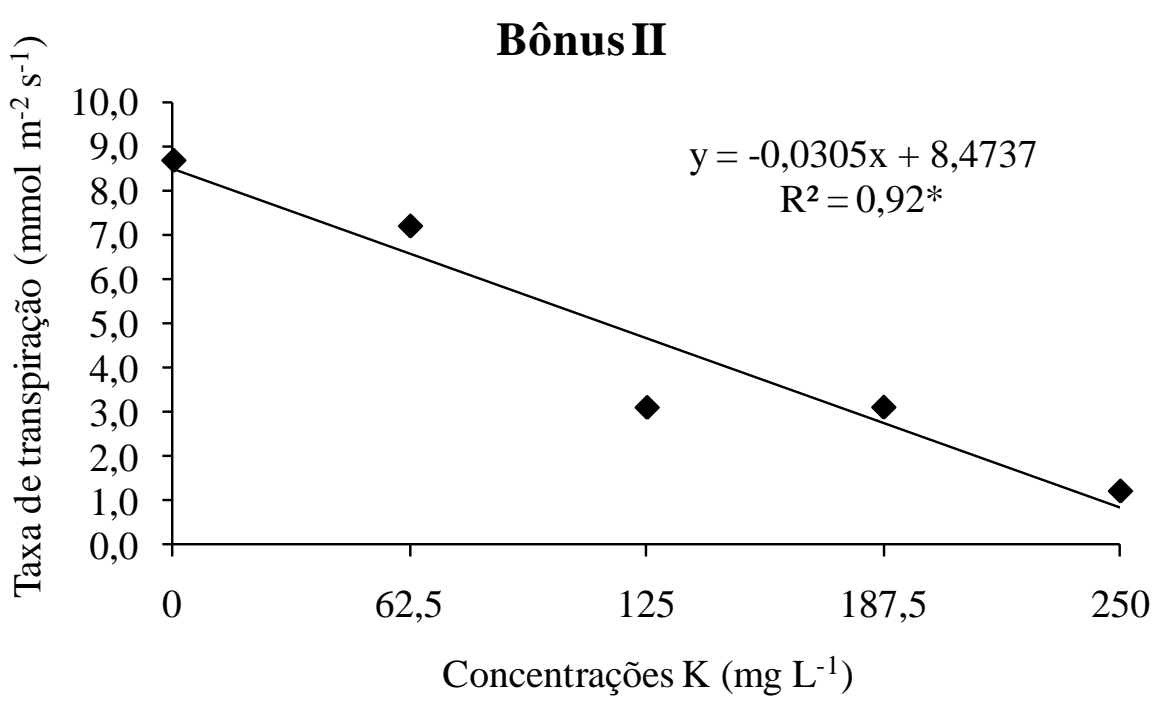

Figura 20. Taxa de transpiração em plantas de 'Bônus II' pé-franco em função das concentrações de potássio aos 26 DAI. São Manuel-SP - FEPP - UNESP/FCA, 2009.

Tabela 23. Dados de temperatura $\left(\mathrm{T}^{\circ} \mathrm{C}\right)$ e radiação fotossinteticamente ativa (PAR) aos 26 DAI. São Manuel-SP - FEPP - UNESP/FCA, 2009.

\begin{tabular}{ccc}
\hline Concentrações K $\left(\mathrm{mg} \mathrm{L}^{-1}\right)$ & $\mathrm{T}^{\circ} \mathrm{C}$ & $\begin{array}{c}\text { Radiação } \\
\text { fotossinteticamente ativa } \\
\left(\mu \mathrm{mol} \mathrm{m}^{-2} \mathrm{~s}^{-1}\right)\end{array}$ \\
\hline 0 & 30 & 1700 \\
62,5 & 32 & 1699 \\
125 & 32 & 1699 \\
187,5 & 29 & 1699 \\
250 & 30 & 1699 \\
\hline
\end{tabular}

$\mathrm{O} \mathrm{ABA}$, assim como o metil jasmonato (MeJa), o ácido salicílico (AS) e o etileno, é considerado fundamental para processos relacionados com a defesa à patógenos em muitas espécies vegetais (ADIE et al., 2007). Estes podem agir isoladamente ou associados e controlar os efeitos uns dos outros.

Aos 41 DAI, as plantas de 'Bônus II' enxertadas com o porta-enxerto abóbora 'Strong Tosa' apresentaram taxa de assimilação líquida de $\mathrm{CO}_{2}$, condutância estomática, taxa de transpiração mais elevadas do que as enxertadas com o melão 'Dinero' (Figuras 21, 22 e 23). 


\section{Taxa de assimilação líquida de $\mathrm{CO}_{2}$}

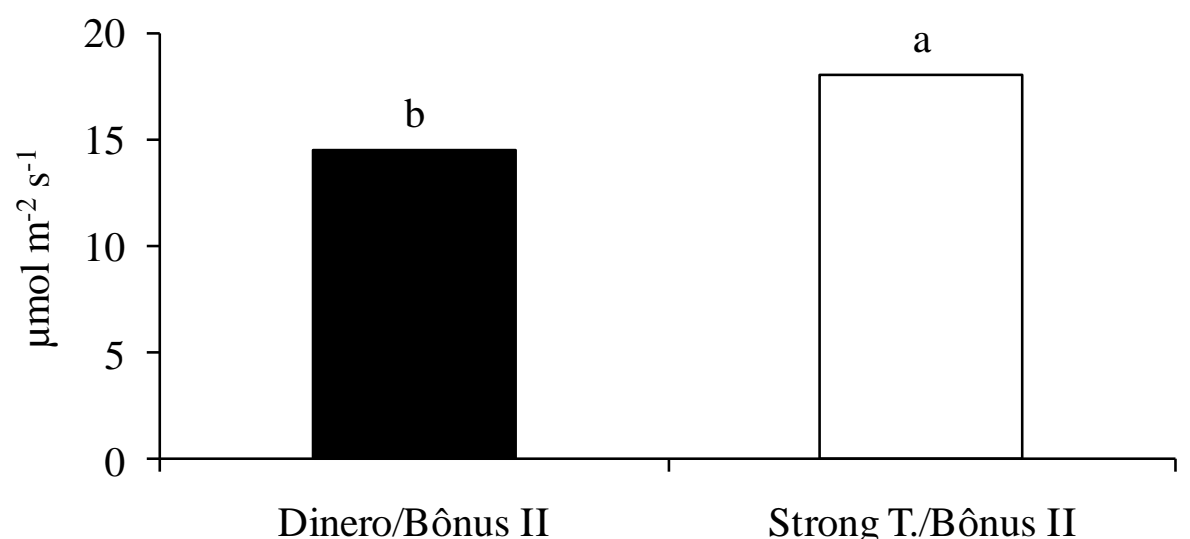

41 Dias após inoculação

Figura 21. Taxa de assimilação líquida de $\mathrm{CO}_{2}$ em plantas enxertadas aos 41 dias após a inoculação. Médias seguidas de mesma letra não diferem entre si pelo teste de Tukey a 5\% de probabilidade. São Manuel-SP - FEPP - UNESP/FCA, 2009.

\section{Condutância estomática}

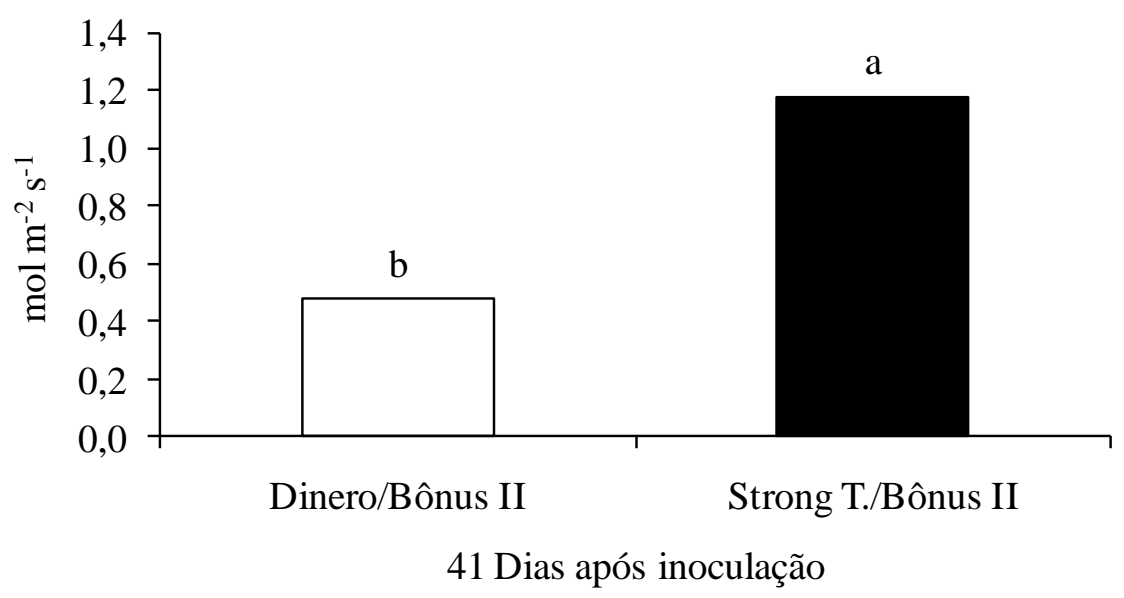

Figura 22. Condutância estomática em plantas enxertadas aos 41 dias após a inoculação. Médias seguidas de mesma letra não diferem entre si pelo teste de Tukey a $5 \%$ de probabilidade. São Manuel-SP - FEPP - UNESP/FCA, 2009. 


\section{Taxa de transpiração}

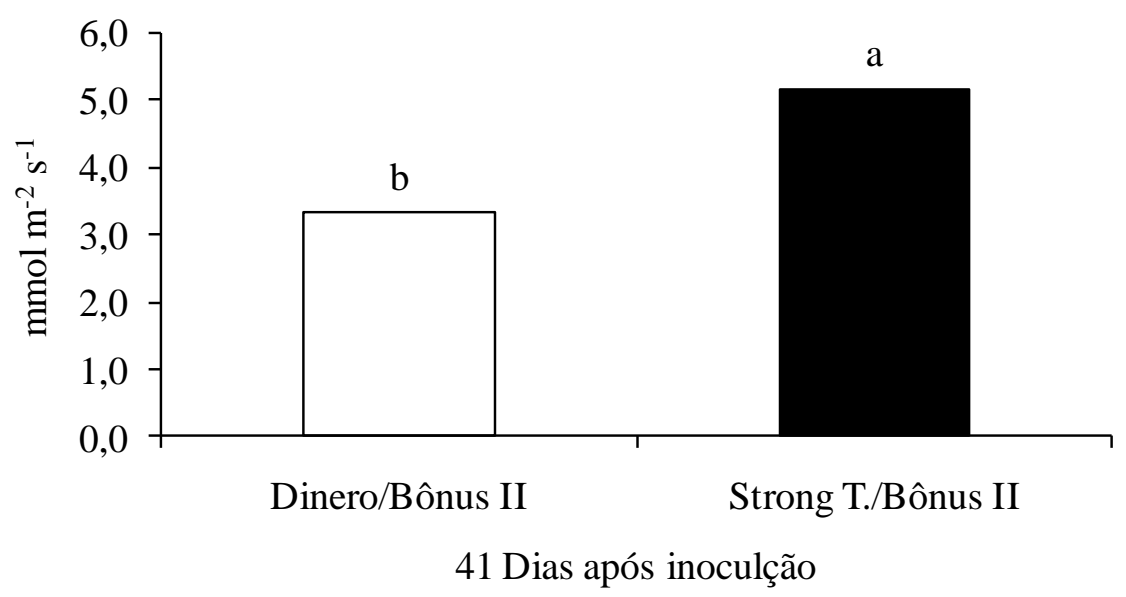

Figura 23. Taxa de transpiração em plantas enxertadas aos 41 dias após a inoculação. Médias seguidas de mesma letra não diferem entre si pelo teste de Tukey a 5\% de probabilidade. São Manuel-SP - FEPP - UNESP/FCA, 2009.

A condutância estomática é recíproca à resistência estomática e varia em função do processo difusivo da fase gasosa, aberturas estomáticas e assimilação fotossintética do mesofilo (WONG et al., 1979). Por outro lado, a condutância estomática diminui em algumas espécies antes que a taxa de assimilação líquida de $\mathrm{CO}_{2}$ em função da sensibilidade a mudanças ambientais, fenológicas e manipulações artificiais que diminuem a transpiração e aumentam a disponibilidade de nutrientes (FIELD 1987 citado por CAÑIZARES et al., 2004).

As plantas de 'Bônus II' enxertadas em melão 'Dinero' apresentaram maior EUA que as enxertadas com abóbora 'Strong Tosa' aos 41 DAI (Figura 24), podendo ser devido a menor taxa de transpiração, pois apesar das plantas diferirem estatisticamente nesta avaliação em relação a taxa de assimilação liquida de $\mathrm{CO}_{2}$ (Figura 21) os valores desta eram próximos. 


\section{Eficiência do uso da água}

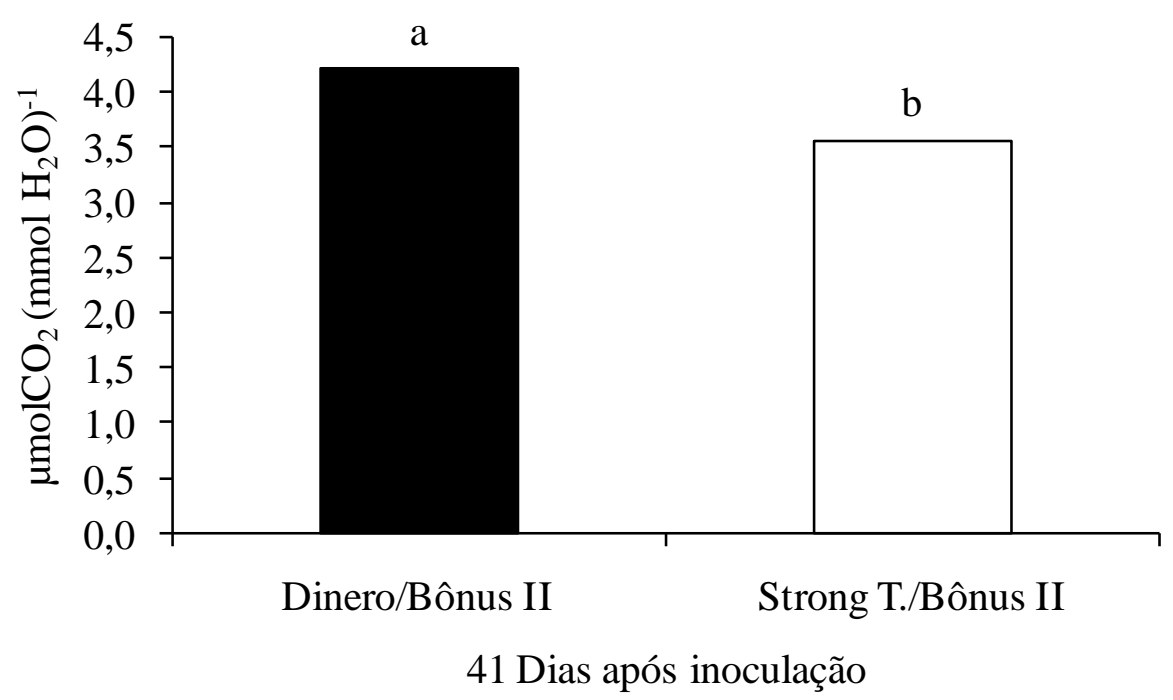

Figura 24. Eficiência do uso da água em plantas enxertadas aos 41 dias após a inoculação. Médias seguidas de mesma letra não diferem entre si pelo teste de Tukey a 5\% de probabilidade. São Manuel-SP - FEPP - UNESP/FCA, 2009.

O aumento da EUA é produzido pela queda da condutância estomática e taxa de transpiração, e é devido à manutenção da taxa de assimilação líquida de $\mathrm{CO}_{2}$ das plantas, mesmo com o fechamento parcial dos estômatos (WOFE, 1994 citado por GUIMARÃES \& RODRIGUES 2002). Quando a concentração de $\mathrm{CO}_{2}$ é alta, o aumento instantâneo da eficiência do uso da água é relacionado com a condutância e transpiração (CAÑIZARES et al., 2004).

De acordo com a análise de regressão polinomial, as concentrações de potássio não influenciaram na taxa de assimilação líquida de $\mathrm{CO}_{2}$ das plantas enxertadas, porém influenciaram de forma linear na condutância estomática e taxa de transpiração das plantas de 'Bônus II' enxertadas com 'Strong Tosa' aos 75 DAI, e não houve efeito significativo sobre a condutância estomática aos 82 DAI (Tabelas 24 e 25). 
Tabela 24. Resumo da análise de variância (quadrados médios) da condutância estomática ( $\left.\mathrm{g}_{\mathrm{s}}\right)$, taxa de transpiração (E) e taxa de assimilação líquida de $\mathrm{CO}_{2}$ (A) nas plantas de 'Bônus II' enxertadas em melão 'Dinero'. São Manuel-SP - FEPP - UNESP/FCA, 2009.

\begin{tabular}{lcc|cccc}
\hline Causa da Variação & \multicolumn{2}{c}{ QM 26 DAI } & \multicolumn{3}{c}{ QM 75 DAI } & QM 82 DAI \\
\hline Variável Significativa & $\mathrm{g}_{\mathrm{s}}$ & $\mathrm{E}$ & $\mathrm{A}$ & $\mathrm{g}_{\mathrm{s}}$ & $\mathrm{E}$ & $\mathrm{g}_{\mathrm{s}}$ \\
Cúbico & $0,95^{\mathrm{ns}}$ & $1,05^{\mathrm{ns}}$ & $25,17^{\mathrm{ns}}$ & $0,0005^{\mathrm{ns}}$ & $0,0004^{\mathrm{ns}}$ & $0,0001^{\mathrm{ns}}$ \\
Quadrático & $0,02^{\mathrm{ns}}$ & $7,19^{\mathrm{ns}}$ & $140,24^{\mathrm{ns}}$ & $0,007^{\mathrm{ns}}$ & $4,43^{\mathrm{ns}}$ & $0,0004^{\mathrm{ns}}$ \\
Linear & $0,18^{\mathrm{ns}}$ & $14,27^{\mathrm{ns}}$ & $131,55^{\mathrm{ns}}$ & $0,013^{\mathrm{ns}}$ & $4^{\mathrm{ns}}, 0^{\mathrm{ns}}$ & $0,006^{\mathrm{ns}}$ \\
\hline
\end{tabular}

*Significativo a 5\% de probabilidade. ${ }^{\text {ns }}$ não significativo a $5 \%$ de probabilidade.

Tabela 25. Resumo da análise de variância (quadrados médios) da condutância estomática $\left(\mathrm{g}_{\mathrm{s}}\right)$, taxa de transpiração (E) e taxa de assimilação líquida (A) nas plantas de 'Bônus II' enxertadas em abobora 'Strong Tosa'. São Manuel-SP - FEPP - UNESP/FCA, 2009.

\begin{tabular}{lcc|ccc|c}
\hline Causa da Variação & \multicolumn{2}{c}{ QM 26 DAI } & \multicolumn{3}{c}{ QM 75 DAI } & QM 82 DAI \\
\hline Variável Significativa & $\mathrm{g}_{\mathrm{s}}$ & $\mathrm{E}$ & $\mathrm{A}$ & $\mathrm{g}_{\mathrm{s}}$ & $\mathrm{E}$ & $\mathrm{g}_{\mathrm{s}}$ \\
Cúbico & $1,23^{\mathrm{ns}}$ & $13,81^{\mathrm{ns}}$ & $43,22^{\mathrm{ns}}$ & $0,0008^{\mathrm{ns}}$ & $3,39^{\mathrm{ns}}$ & $0,012^{\mathrm{ns}}$ \\
Quadrático & $0,96^{\mathrm{ns}}$ & $12,80^{\mathrm{ns}}$ & $73,78^{\mathrm{ns}}$ & $0,003^{\mathrm{ns}}$ & $3,02^{\mathrm{ns}}$ & $0,014^{\mathrm{ns}}$ \\
Linear & $0,27^{\mathrm{ns}}$ & $9,28^{\mathrm{ns}}$ & $61,36^{\mathrm{ns}}$ & $0,007^{*}$ & $7,07^{*}$ & $0,016^{\mathrm{ns}}$ \\
\hline
\end{tabular}

* Significativo a $5 \%$ de probabilidade. ${ }^{\text {ns }}$ não significativo a $5 \%$ de probabilidade.

Ao aumentar as concentrações de $\mathrm{K}$ ocorreu aumento da condutância estomática e taxa de transpiração nas plantas enxertadas com abóbora 'Strong Tosa' aos 75 DAI (Figuras 25 e 26), diferente do que ocorreu com 'Bônus II' pé-franco aos 26 DAI. 


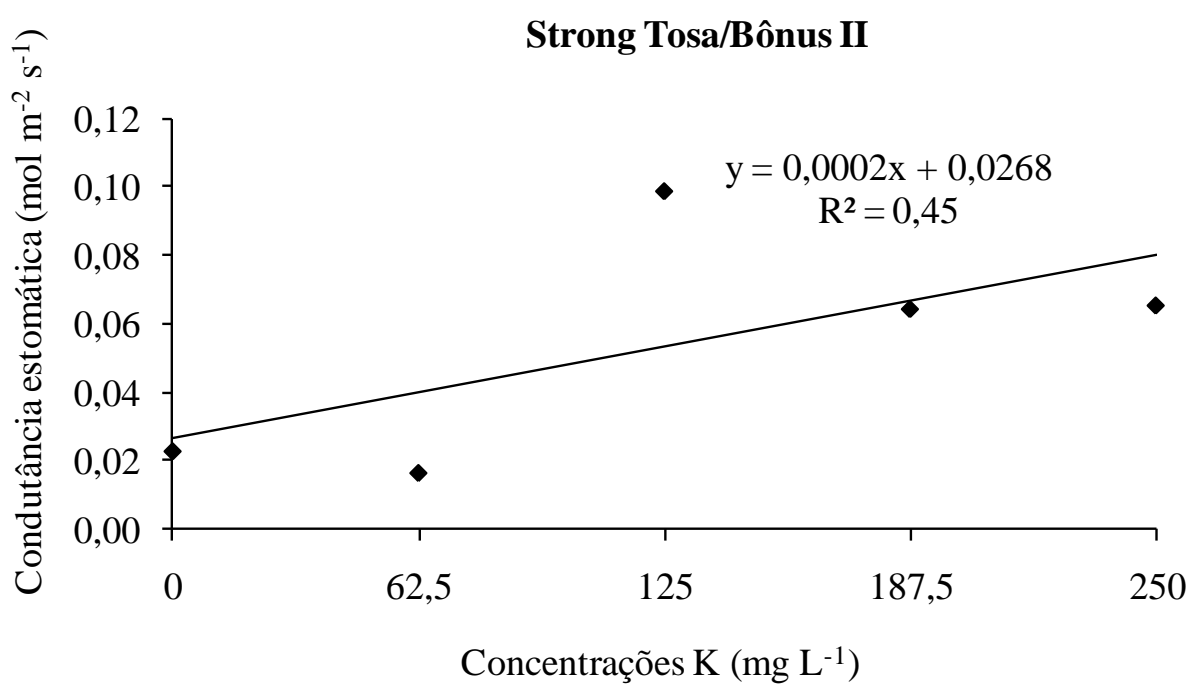

Figura 25. Condutância estomática em plantas de 'Bônus II' enxertadas com 'Strong Tosa' em função das concentrações de potássio aos 75 dias após a inoculação. São Manuel-SP - FEPP UNESP/FCA, 2009.

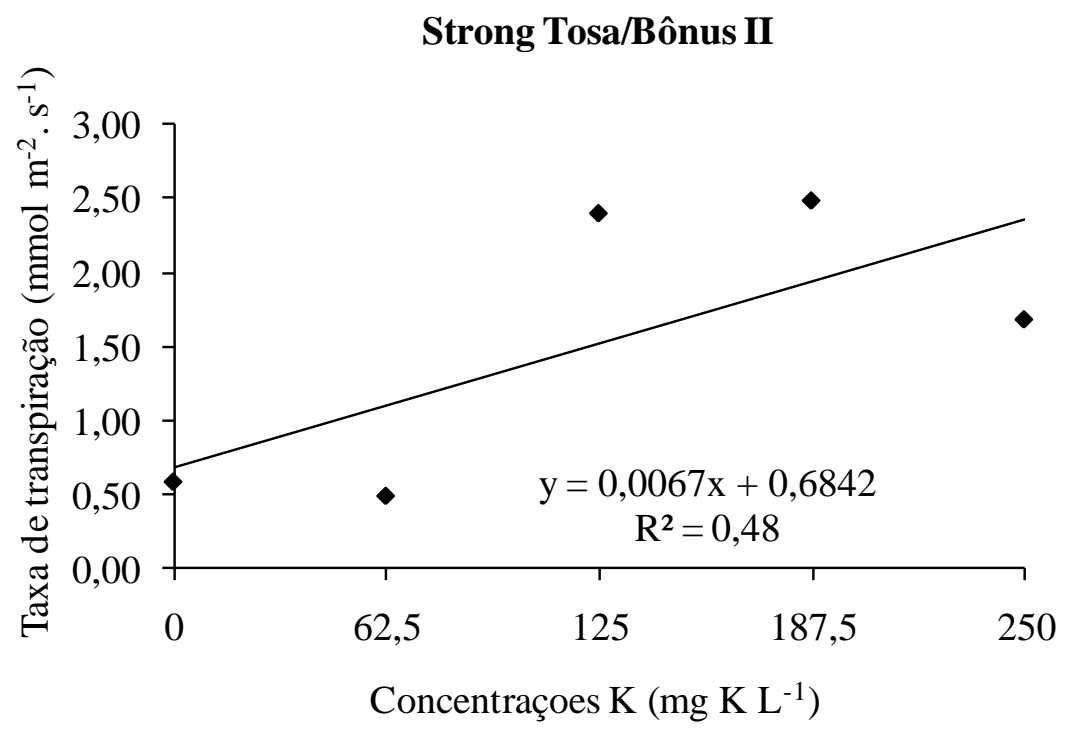

Figura 26. Taxa de transpiração em plantas de 'Bônus II' enxertadas com 'Strong Tosa' em função das concentrações de potássio aos 75 dias após a inoculação. São Manuel-SP - FEPP UNESP/FCA, 2009. 
Antes do carregamento do floema, o K está envolvido na fotossíntese, começando pelo funcionamento dos estômatos e continuando pela fixação de $\mathrm{CO}_{2}$ em presença de luz.

$\mathrm{O}$ aumento nas concentrações de $\mathrm{K}$, neste estudo pode ter afetado o potencial osmótico e a absorção das plantas, pois Malavolta (2006) afirma que aumentando a concentração de K na célula, aumenta também a sua capacidade de absorver água.

O potencial osmótico é definido pela diferença na concentração de solutos entre os dois lados da membrana celular e o $\mathrm{K}$ é o cátion principal que afeta este potencial. Quando ocorre maior concentração de solutos dentro das células guarda dos estômatos, a água se movimenta para dentro dessas células fazendo com que elas fiquem túrgidas e se abram, favorecendo também a maior taxa de transpiração como observado neste estudo.

A abertura estomática é um efeito altamente específico do K junto com a luz. Faltando $\mathrm{K}$, os estômatos não se abrem regularmente, há menor entrada de $\mathrm{CO}_{2} \mathrm{e}$, portanto, há menor intensidade fotossintética (MALAVOLTA, 1980)

\subsubsection{Condutividade elétrica e pH da solução do solo}

Nos tratamentos 'Bônus II' (pé-franco) e concentrações de potássio 0, 125 e $250 \mathrm{mg} \mathrm{L}^{-1}$, a condutividade elétrica (CE) da solução do solo não ultrapassou 2,0 dS m m $^{-1}$ não prejudicando o desenvolvimento das plantas (Figura $27 \mathrm{~A}$ ), pois segundo resultados

apresentados por Dias et al. (2006) a condutividade acima de 4,0 $\mathrm{dS} \mathrm{m}^{-1}$ pode prejudicar o híbrido 'Bônus II' principalmente na fase de produção de frutos. 


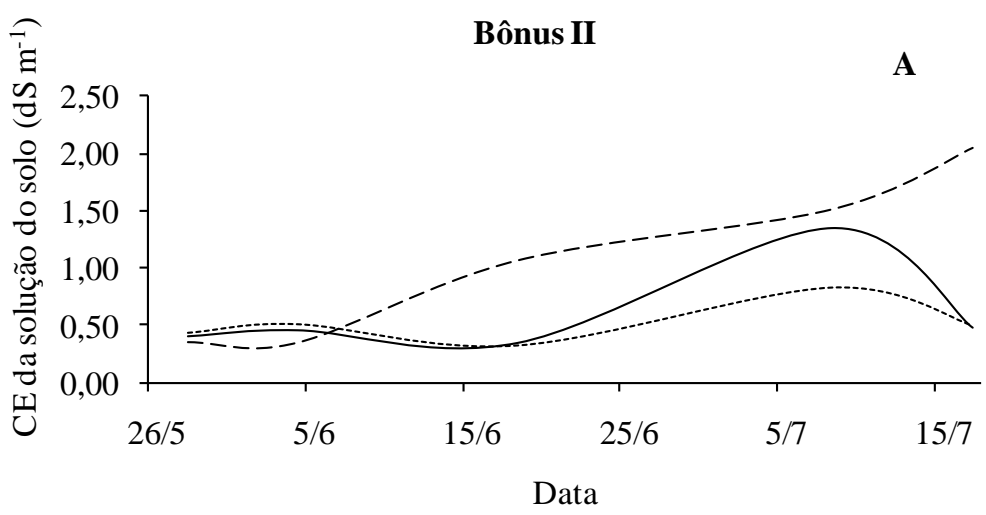

$\cdots-125 \mathrm{mgK} / \mathrm{L} \quad---\cdot 250 \mathrm{mgK} / \mathrm{L}$

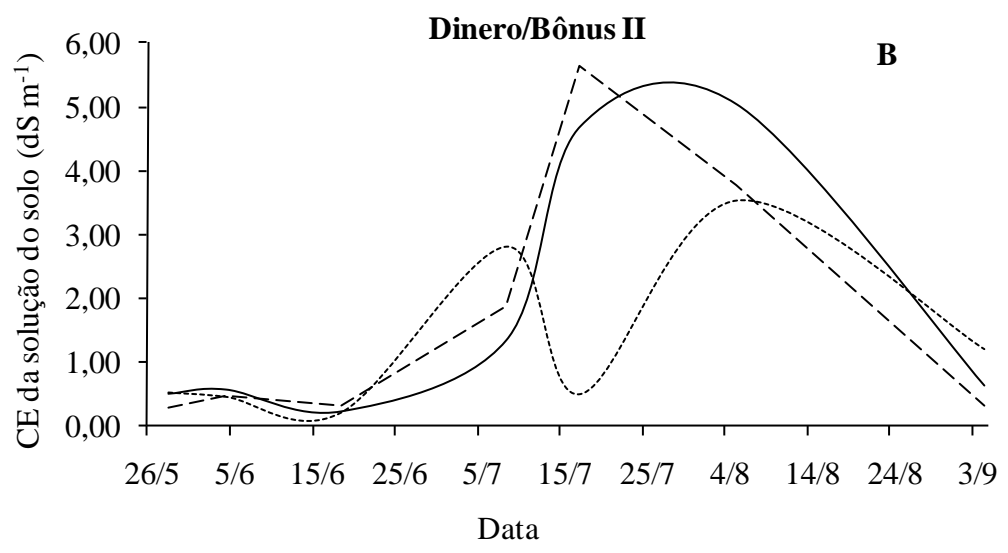

$\cdots-\cdots \cdot 0 \mathrm{mgK} / \mathrm{L} \quad-125 \mathrm{mgK} / \mathrm{L} \quad---\cdot 250 \mathrm{mgK} / \mathrm{L}$

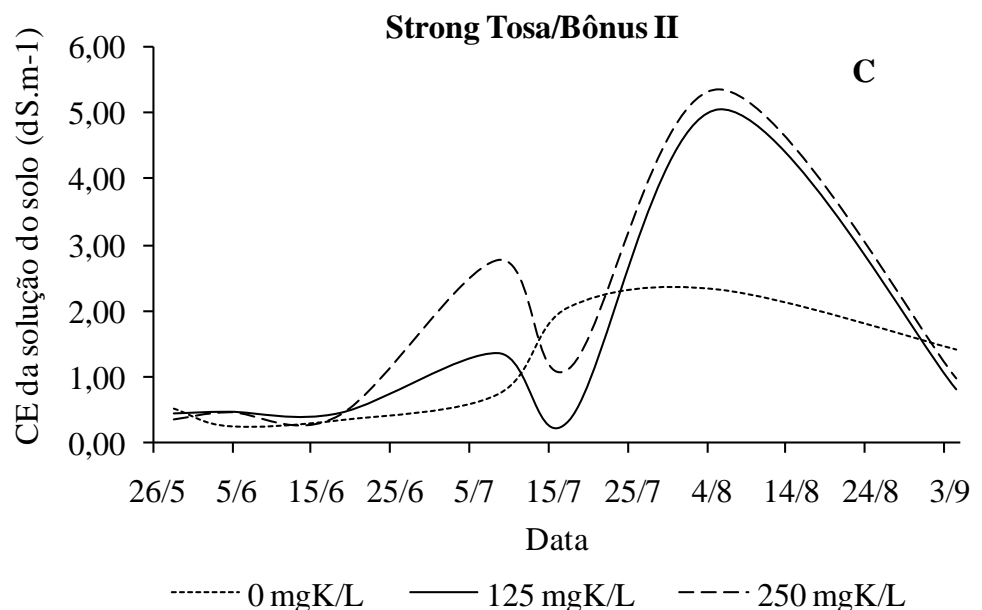

Figura 27 A, B e C. Condutividade elétrica (CE) da solução do solo nos tratamentos de 'Bônus II' pé-franco e enxertado nos porta-enxertos 'Dinero e 'Strong Tosa' com as concentrações de potássio 0,125 e $250 \mathrm{mg} \mathrm{L}^{-1}$. 
Nas plantas de 'Bônus II' enxertadas nos porta-enxertos 'Dinero' e 'Strong Tosa' nas concentrações de potássio 125 e $250 \mathrm{mg} \mathrm{L}^{-1}$, a condutividade elétrica atingiu até 5,0 dS m ${ }^{-1}$ (Figura $27 \mathrm{~B}$ e C) devido às maiores quantidades de fertilizante aplicadas e foi necessário uma aplicação de lâmina de água maior para diminuir a salinidade do solo e conseqüentemente a condutividade elétrica evitando que a mesma fosse um fator prejudicial ao desenvolvimento das plantas.

$\mathrm{O}$ pH da solução do solo durante praticamente todo o período do experimento nos tratamentos de 'Bônus II' pé-franco e enxertado nos porta-enxertos 'Dinero e 'Strong Tosa' com as concentrações de potássio 0,125 e $250 \mathrm{mg} \mathrm{L}^{-1}$ permanceu na faixa de 5,5 a 7,0 (Figura 28 A, B e C), concordando com Moreira et al. (2009) que relatam que o pH $\left(\mathrm{em} \mathrm{CaCl}_{2}\right)$ deve se situar entre 5,5 e 6,5 e Raij (1991) que relata que o meloeiro requer solos com $\mathrm{pH}$ próximo da neutralidade, não prejudicando o desenvolvimento da cultura. 

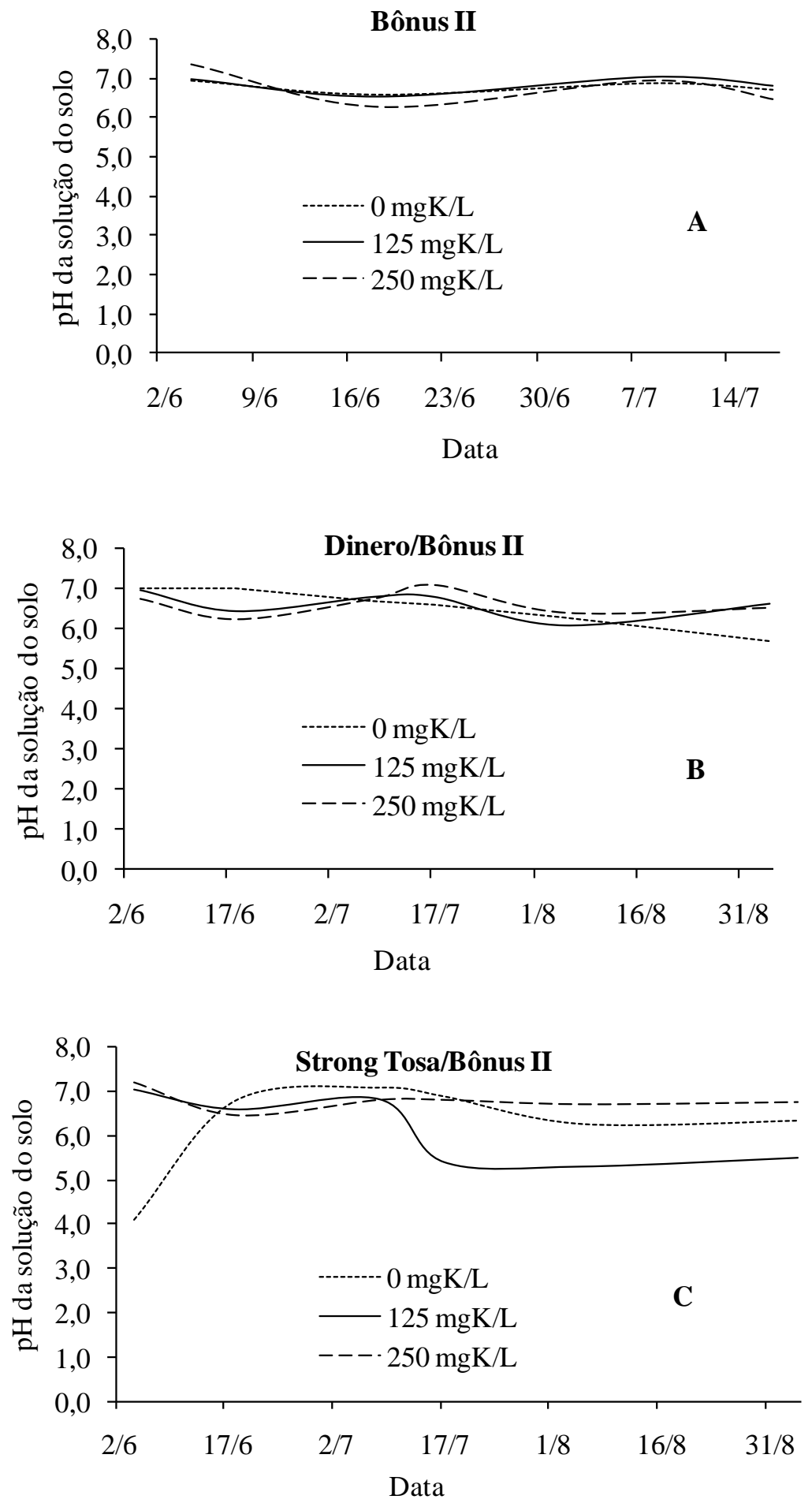

Figura 28 A, B e C. pH da solução do solo nos tratamentos de 'Bônus II' pé-franco e enxertado nos porta-enxertos 'Dinero e 'Strong Tosa' com as concentrações de potássio 0, 125 e $250 \mathrm{mg} \mathrm{L}^{-1}$. 


\section{CONSIDERAÇÕES GERAIS}

O potássio tem sido um dos nutrientes mais estudados em relação à resistência de plantas às doenças e pragas e nas duas últimas décadas isto tem-se intensificado, com resultados obtidos com algumas doenças ou pragas em algumas plantas. Contudo, nos experimentos realizados neste estudo, constatou-se que este nutriente não influenciou na doença causada pelo fungo $D$. bryoniae. Entretanto, estudos realizados neste tema, levam a concluir que outros nutrientes poderiam atuar sobre doenças, como por exemplo, o magnésio que talvez possa contribuir melhor para dirimir a manifestação do $D$. bryoniae na cultura do meloeiro.

D. bryoniae não é fungo de solo, porém sobrevive por muito tempo no solo em locais em que já ocorreu incidência, por isso tanto no Brasil quanto no exterior tem-se estudado com sucesso a enxertia como alternativa de controle deste fungo, mesmo porque o controle químico tem sido ineficiente, podendo vir a ser uma ferramenta para os produtores de melão e demais cucurbitáceas em ambiente protegido, como já é de uso mais conhecido para controle alternativo da raça 1 e 2 de Fusarium oxysporum f. sp. melonis, e alguns outros distúrbios fisiológicos que ocorrem nas cucurbitáceas.

O objetivo desta pesquisa foi estudar a enxertia e a influência do potássio e para isso o período de execução do ensaio não foi adequado para a cultura em si, não atingindo uma produção de frutos adequados, mas mesmo assim foi observado que alguns frutos, em plantas enxertadas sobreviventes, atingiram ponto de maturação, porém não 
apresentaram massa comercial, em conseqüência do clima não ter sido favorável para a produção de frutos, embora tenha sido ideal para avaliar a incidência de doença.

As plantas de 'Bônus II' enxertadas em abóbora 'Strong Tosa' apresentaram porte e frutos menores que as enxertadas em melão 'Dinero', entretanto, outras pesquisas deveriam ser realizadas em situações climáticas favoráveis à produção para que se possa verificar, se este resultado se deve à compatibilidade entre porta-enxerto/enxerto.

As plantas apresentaram sintomas característicos de salinização do solo, mais evidentes nos tratamentos que receberam concentrações de $\mathrm{K}$ mais altas, como endurecimento e encarquilhamento das folhas. Também se verificou o aparecimento de uma crosta ou pontuações brancas sobre o solo, caracterizando uma deposição de sais, provavelmente devido ao volume do vaso limitar o sistema radicular, dificultando sua expansão e conseqüentemente menor absorção, notando-se também rachaduras em frutos de plantas sobreviventes, talvez devido à competição entre cálcio e potássio.

No final do ciclo, observou-se uma infestação de cercosporiose ou mancha-de-cercóspora, sendo que as poucas plantas pé-franco sobreviventes apresentaram maior infestação da doença que as enxertadas. As plantas enxertadas com melão 'Dinero' mostraram maior infestação em relação às enxertadas com abóbora 'Strong Tosa', podendo ser devido à interação porta-enxerto/enxerto, porém exige estudo relacionado. 


\section{CONCLUSÕES}

De acordo com os resultados obtidos nos experimentos pode-se concluir que:

O porta-enxerto melão 'Dinero' foi susceptível, os porta-enxertos cabaça 'Calabash TI-191', melancia 'Ojakkyo' foram resistentes e o porta-enxerto abóbora 'Strong Tosa' moderadamente resistente ao fungo D. bryoniae;

Os porta-enxertos cabaça 'Calabash', melancia 'Ojakkyo' e abóbora 'Strong Tosa' podem ser utilizados como alternativa para tentar controlar o fungo $D$. bryoniae, causador da doença crestamento gomoso ou podridão gomosa no meloeiro rendilhado;

As plantas de 'Bônus II' enxertadas em abóbora 'Strong Tosa' foram mais resistentes que as enxertadas em melão 'Dinero' e as pé-franco foram susceptíveis;

As concentrações de potássio testadas não influenciaram no tamanho da lesão e na sobrevivência das plantas, porém influenciaram na condutância estomática e transpiração das plantas. 


\section{REFERÊNCIAS BIBLIOGRÁFICAS}

ADIE, B.A.; PEREZ-PEREZ, J.; PEREZPEREZ, M.M.; GODOY, M.; SOLANO, R. Aba is an essential signal for plant resistance to pathogens affecting JA biosynthesis and the activation of defenses in Arabidopsis. Plant Cell, v. 19, p. 1665-81, 2007.

AIST, J. R. Papiliae and related wound plugs ofplant cells. Ann Rev Phytopathology, St. Paul, v. 14, p. 145-163, 1976.

AMTMANN, A; Troufflard, S; ARMENGAUD, P. The effect of potassium nutrition on pest and disease resistance in plants.Physiol Plant. Epub; Mar.7. 133(4):682-91, 2008.

BRANDÃO FILHO, J. U. T.; VASCONCELLOS, M. A. S. A cultura do meloeiro. In: GOTO, R.; TIVELLI, S. W. (Orgs.). Produção de hortaliças em ambiente protegido: condições subtropicais. São Paulo: Funep, 1998. p. 161-193.

BRASIL. 2003. Ministério da Integração Nacional. Secretaria de Infra-Estrutura Hídrica. Departamento de Desenvolvimento Hidroagrícola. Melão. 12p. (FrutiSéries. Ceará. Melão, 2).

CAMARGO, A.M.M.P. ; CAMARGO, F. P.; CAMARGO FILHO, W. P. Distribuição Geográfica da Produção de Hortaliças no Estado de São Paulo: participação no País, concentração regional e evolução no período 1996-2006. Informações Econômicas, SP, v.38, n.1, p. 28-35, jan. 2008. 
CAMPBELL, C.L. \& MADDEN, L.V. Introduction to Plant Disease Epidemiology. New York, John Wiley, 1990. 532p.

CAÑIZARES, K. A. L. Enxertia, potássio e magnésio na nutrição, desenvolvimento e produção de pepino. 2001. 158f. Dissertação (Mestrado em Agronomia)-Faculdade de Ciências Agronômicas, Universidade Estadual Paulista, Botucatu, 2001.

CAÑIZARES, K.A.L.; RODRIGUES, J.D.; GOTO, R. Crescimento e índices de troca gasosa em plantas de pepino irrigadas com água enriquecida com CO2. Horticultura Brasileira, Brasília, v.22, n.4, p.706-711, out-dez 2004.

CHIU, W. F.; WALKER, J. C. Physiology and pathogenicity of the cucurbit black rot fungus. A. Agric. Res. (Washington), v. 78, p. 589-615, $1949 \mathrm{~b}$.

CRINO, P.; BIANCO, C.; ROUPHAEL, Y.; COLLA G.; SACCARDO, F.; PARATORE, A. Evaluation of rootstock resistance to Fusarium wilt and gummy stem blight and effect on yield and quality of a grafted 'Inodorus' melon. HortScience. 2007; 42(3): 521-525.

DIAS, N. S.; DUARTE, S.N.; MEDEIROS, J.F.; FILHO, F.T. Salinidade e manejo da fertirrigação em ambiente prortegido. II. Efeitos sobre o rendimento do meloeiro. Irriga, Botucatu, v. 11, n.3, p. 376-383, julho-setembro, 2006.

DUSI, A.N. Diagnóstico da cultura do melão. Horticultura Brasileira 9:101. 1991.

DUTRA, I. Produtividade e qualidade de frutos de melão pele de sapo em função de diferentes níveis de irrigação e adubações nitrogenadas e potássica. 2005. 99f. Tese (Doutorado em Agronomia) -Faculdade de Ciências Agronômicas, Universidade Estadual Paulista, Botucatu, 2005.

EMPRESA BRASILEIRA DE PESQUISA AGROPECUARIA. Sistema Brasileiro de Classificação de Solos. Rio de Janeiro: EMBRAPA/CNPSO. 412 p. 1999.

ESPÍNDOLA CR, TOSIN WAC; PACCOLA AA. Levantamento pedológico da Faz. Experimental São Manuel. In: CONG. BRAS. CIÊNCIA DO SOLO.,1974, Santa Maria. Anais... Santa Maria: SBCS, 1974. p.650-651. 
FILGUEIRA, F. A. R. Novo manual de olericultura :agrotecnologia moderna na produção e comercialização de hortaliças. $3^{\mathrm{a}}$ ed. Viçosa, MG: Ed. UFV, 2007. 421p.

GOMES, M. M. A. et al . Interactions between leaf water potential, stomatal conductance and abscisic acid content of orange trees submitted to drought stress. Braz. J. Plant Physiol., Londrina, v. 16, n. 3, dez. 2004.

GOTO, R.; SANTOS, H. S.; CAÑIZARES, K. A. L. Enxertia em hortaliças. $1^{a}$ Ed. Botucatu: Editora UNESP, 2003. 85 p.

GUALBERTO, R.; RESENDE, F.V.; LOSAOS, P.H.L. Produtividade e qualidade do melão rendilhado em ambiente protegido, em função do espaçamento e sistema de condução. Horticultura Brasileira, Brasília, v.19, n.3, p.240-3, nov. 2001.

GUIMARÃES, V.F.; RODRIGUES, J.D. Respostas fisiológicas do tomateiro ao enriquecimento com dióxido de carbono, via água de irrigação, em cultivo protegido. Botucatu, 2002. 62 p. Relatório Científico (Pós-Doutorado) UNESP.

HÖMHELD, V. Efeitos do potássio nos processos da rizosfera e na resistência das plantas às doenças. In: TSUIOSHI, Y.; ROBERTS, T. L (Eds). Potássio na Agricultura Brasileira. Anais do Simpósio sobre Potássio na Agricultura Brasileira. Piracicaba, 2005, 841 p.

HOYOS, E. P. Influencia de diferentes porta-injertos sobre La producción de pepino corto tipo español, cultivado em invernadero em la zona central española. Horticultura Argentina (Mendoza), v. 19, n. 46, p. 41, 2000.

HUCITEC. Comissão de elaboração da história dos 80 anos da imigração japonesa no Brasil. Uma epopéia moderna: 80 anos da imigração japonesa no Brasil. São Paulo, HUCITEC: Sociedade Brasileira de Cultura japonesa, 1992. p. 467.

ITO, L.A.; BRAZ, L.T.; CASTOLDI, R.; CHARLO, H.C.O. Response of rootstocks to stem canker and the production and quality of melon under protected cultivation. XXVII International Horticultural Congress - IHC2006: International Symposium on Seed Enhancement and Seedling Production Technology. ISHS Acta Horticulturae 771.

ITO, L.A.; BRAZ, L.T.; CASTOLDI, R.; CHARLO, H.C.O.; CAMARGO, M. Seleção de portas enxertos resistentes ao Cancro da haste e seus efeitos na produtividade de melão 'Bônus 2'. Rev. Bras. Frutic., Jaboticabal - SP, v. 31, n. 1, p. 262-267, Março 2009. 
LARCHER, W. Ecofisiologia Vegetal. São Carlos: Editora RIMA, 2000. 531p.

LIANG, J.; ZHANG, J. \& WONG, M.H. Can stomatal closure caused by xilem ABA explain the inhibition of leaf photosynthesis under soil drying? Photosynthesis Research, The Hague, 51:149-159, 1997.

KANO, C. Extrações de nutrientes pelo meloeiro rendilhado cultivado em ambiente protegido com a adição de potássio e $\mathbf{C O}_{2}$ na água de irrigação. 2002. 102 f. Dissertação (Mestrado em Agronomia) Escola Superior de Agricultura Luiz de Queiroz, Piracicaba, 2002.

KAWAIDE, T. Utilization of rooststocks in cucurbis production in japan. JARQ (Jpn. Agric. Res. Q.), v. 18, p. 284-9, 1985.

KIMATI, H. et al,. Manual de Fitopatologia. $4^{a}$ ed. São Paulo. Agronômica Ceres, 2005. 2 v.: il.

KUROZAWA, C. \& PAVAN. M. A. Doenças das cucurbitáceas. In: Kimati, H.; Amorim, L.; Rezende, J. A. M.; Bergamin Filho, A.; Camargo, L. E. A. (Eds.). Manual de Fitopatologia: Doenças das plantas cultivadas, 2. 4ed. São Paulo: Ceres. 2005. p. 293-307.

MALAVOLTA, E. Manual de nutrição mineral de plantas. São Paulo: Editora Agronômica Ceres, 2006. 638 p.

MALAVOLTA, E. Adubação mineral e sua relação com doenças das plantas - a visão de um nutricionista de plantas. Em: Workshop A interface solo-raiz (rizosfera) e relações com a disponibilidade de nutrientes, a nutrição e as doenças de plantas. Potafos, Esalq, CEA. Piracicaba, 1998, 60p.

MALAVOLTA, E. Elementos de nutrição mineral de plantas. São Paulo. Ed. Agronômica Ceres. 1980.

MÁRMOL, J. R. Cultivo de melón en invernadero. Edita: Junta de Andalucía, Consejería de Agricultura y Pesca.

MARSCHNER, H. Mineral nutrition of higher plants. London : Academic, 1995, 889 p. 
MARQUES, J. H. M.; BONALDO,S. M.; GASPAROTTO, F.; CAIXETA ,M. P.; COLELLA, J. C. L.; VIDA, J. B. Reação de híbridos de melão nobre, pepino japonês e melancia a Didymella bryoniae, agente causal da podridão gomosa. Anais XV EAIC e VI EPUEPG, 2006, Ponta Grossa. XV EAIC e VI EPUEG, 2006.

MATIELLO, R. R.; BARBIERI, R. L.; CARVALHO, F. I. F. Resistência das plantas a moléstias fúngicas. Ciência Rural, Santa Maria, v.27, n.1, p.161-168, 1997.

MOREIRA, S.R.; MELO, A.M.T. de; PURQUERIO, L.F.V.; TRANI, P.E.; NARITA, N. Melão (Cucumis melo L.). 2009. Artigo em Hypertexto. Disponível em:

<http://www.infobibos.com/Artigos/2009_3/melao/index.htm>. Acesso em: 10/11/2009.

NAKAMEA, I.J. Agrianual - anuário da agricultura brasileira. São Paulo: FNP Consultoria e Agroinformativos, 2004. 496p.

NEERGAARD, E. Studie of Didymella bryoniae (Auersw) Rehm: development in the host. J. Phytopathol. (Berl.), v. 127, p. 107-115, 1989 b.

NEGREIROS, M.Z.; MEDEIROS, J.F.; SALES JÚNIOR, R.; MENEZES, J.B. Cultivo de melão no pólo agrícola Rio Grande do Norte/ Ceará. Horticultura Brasileira, Brasília, v.21, n.3, p.1-1, 2003.

ODA, M. New grafting methods for fruit bearing vegetables in Japan. Japan Agricultural Research Quartely, Yatabe, v.29, p.187-94, 1995.

PERRENOUD, S.: Potassium and Plant Health. Bern International Potash Institute, 2nd. completely revised. 1990, $365 \mathrm{p}$.

PRABHU, A.S.; FAGERIA, N.K.; HUBER, D.M. Potassium nutrition and plant diseases. In: (eds) Datnoff, L.E; Elmer, W.H.; Huber, D.M. Mineral Nutrition and Plant Disease. The American Phytopathological Society Press, Saint Paul, 2007.

PURQUERIO, L. F. V. Concentração de nitrogênio na solução nutritiva e número de frutos por planta sobre a produção e qualidade dos frutos do meloeiro. 2002. $43 \mathrm{f}$. Dissertação (Mestrado em Agronomia)-FCAMV, Universidade Estadual Paulista, Jaboticabal, 2002. 
RAIJ, B. Fertilidade do solo e adubação. São Paulo: Agronômica Ceres, 1991. p. 118-36.

REICHARDT, K.; TIMM, L. C. Solo, planta e atmosfera: conceitos, processos e aplicações. Barueri: Manole, 2004. 478 p.

RIZZO, A. A. do N. Obtenção e avaliação de genótipos de melão rendilhado em ambiente protegido. 2004. 38 f. Tese (Doutorado em Agronomia Produção Vegetal) Universidade Estadual Paulista, Jaboticabal, 2004.

ROBERT, D.M.; HARMON, A.C. Calcium-modulated proteins: targets of intracellular calcium in higher plants. Annu. Rev. Plant. Physiol., V. 43, p. 375-414, 1992.

SANTOS, G. R.; CAFÉ-FILHO, A.C.; SABOYA, L.M.F. Controle químico do crestamento gomoso do caule na cultura da melancia. Fitopatologia Brasileira 30:155-163. 2005.

SILVA, T.J.A.; MACHADO, C.C.; BONFIM-SILVA, E.D.; COELHO, R.D. Influência do manejo da irrigação no meloeiro rendilhado cultivado em ambiente protegido. Eng. Agríc., Jaboticabal, v.25, n.3, p.722-731, set./dez. 2005.

SIVIERO, AMAURI et al . Avaliação de métodos de inoculação de Phytophthora parasitica em plântulas e plantas jovens de citros. Fitopatol. bras., Brasília, v. 27, n. 6, Nov. 2002.

TAIZ, L., ZEIGER, E. Fisiologia vegetal. Trad. Eliane Romanato Santarém...[et al.]. $3^{\mathrm{a}}$ ed. Porto Alegre.Art méd, 2004.

TRIONFETTI-NISINI, P; BUZI, A; GRANATI, E; CHILOSI, G; CRINO, P; MAGRO, P. Screening for resistance to Didymella bryoniae in rootstocks of melon. Bulletin-OEPP. 2000; 30(2): 231-234.

TSUTSUMI, C.Y. Triagem de população de melão (cucumis melo L.) para resitência à didymella bryoniae (Auersw) Rehm. 1995. 89f. Dissertação de mestrado (AgronomiaHorticultura)-Faculdade de Ciências Agronômicas, Universidade Estadual Paulista, Botucatu, 1995.

VAN GENUCHTEN, M. Th. A closed-form equation for predicting the conductivity of unsatured soils. Soil Science Society of America Journal, v. 44, p. 892-898, 1980. 
VARGAS, P. F.; CASTOLDI, R.; CHARLO, H. C. O.; BRAZ, L. T. Qualidade de melão rendilhado (cucumis melo 1.) em função do sistema de cultivo. Ciênc. agrotec., Lavras, v. 32, n. 1, p. 137-142, jan./fev., 2008.

VERZIGNASSI, J.R; VIDA, J.B.; GASPAROTTO, F.; CORTEZ, G.L.S.; LORENZETTI, E.R.; FARIA, G. de S.; TESSMANN, D.J. \& SEVERINO, J.J. Método do palito para inoculação de Didymella bryoniae em melão nobre e pepino "japonês". Fitopatologia Brasileira, 29(suplemento):154, 2004.

VIDA, J.B., ZAMBOLIM, L., TESSMANN, D.J., BRANDÃO FILHO, J.U.T., VERZIGNASSI, J.R. \& CAIXETA, M.P. Manejo de doenças de plantas em cultivo protegido. Fitopatologia Brasileira, 29(4), p.355-372. Jul-Ago. 2004 a.

VIDA, J.B., TESSMANN, D.J., ZAMBOLIM, L., VERZIGNASSI, J.R. \& BRANDÃO FILHO, J.U.T. Controle da podridão gomosa em melão rendilhado em cultivo protegido por sanitização de ferramenta de poda. Fitopatologia Brasileira, 29:626-630, Nov-Dec. 2004b .

VIDA, J.B., KUROZAWA, C., ESTRADA, K.R.F.S. \& SANTOS, H.S. Manejo fitossanitário em cultivo protegido. In: Goto, R. \& Tivelli, S.W. (Eds.) Produção de hortaliças em ambiente protegido: condições subtropicais. Botucatu: Editora Unesp. 1997. pp.53-104.

VIDA, J.B.; BRANDÃO FILHO, J.U.T.; NUNES, W.M..C.; SOUTO, E.R. Avaliação de perdas causadas por Didymella bryoniae na cultura do melão em estufas plásticas. Fitopatologia brasileira, v. 21(Suplemento), p.409, 1996.

VIDA, J.B. Manejo de doenças em cultivos protegidos. In: Brandão Filho, J.U.T., Contiero, R.L. \& Andrade, J.M.B. Cultivo protegido: Encontro de Hortaliças da Região Sul, 9, Encontro de Plasticultura da Região Sul, 6. Maringá. 1994. pp.25-30.

VIDA, J.B., SOUTO, E.R. \& NUNES, W.M.C. Perdas causadas por Mycosphaerella melonis na cultura do melão em estufas plásticas. Fitopatologia Brasileira 18:324. 1993 (Resumo).

ZAMBOLIM, L., VENTURA, J. A. Resistência a doenças induzida pela nutrição mineral. Rev An Patol Plantas, Passo Fundo, v. 1,p.275-318, 1993. 
ZAMBOLIM, L. Estratégias de manejo integrado de doenças. Em: Workshop A interface solo-raiz (rizosfera) e relações com a disponibilidade de nutrientes, a nutrição e as doenças de plantas. Potafos, Esalq, CEA. Piracicaba, 1998, 40p.

ZAMBOLIM, L., COSTA, H., LOPES, C.A. \& VALE, F.X.R. Doenças de hortaliças em cultivo protegido. In: Zambolim, L., Vale, F.X.R., Costa, H. (Eds.) Controle de doenças de plantas-hortaliças. v.1. Viçosa. Universidade Federal de Viçosa. 2000. p.373-407.

YAMAKAWA, K. Use of rootstocks in solanaceous fruit vegetable production in Japan. Jpn. A. R. Q., v. 15, n. 3, p. 175-79, 1982.

WALTERS, D.R \& BINGHAM, I.J. Influence of nutrition on disease development caused by fungal pathogens: implications for plant disease control. Annals of Applied Biology, 151, n.3, p.307-324, 2007.

WHITAKER, T. W \& DAVIS, G. N. Cucurbits: botany, cultivation and utilization. London: Leonard Hill, 1962. 250 p. 